by Ireneusz Walaszczyk ${ }^{1 *}$, Stanislav Čech ${ }^{2}$, James S. Crampton ${ }^{3}$, Zofia Dubickal, Christina Ifrim ${ }^{4}$, Ian Jarvis ${ }^{5}$, William J. Kennedy ${ }^{6,7}$, Jackie A. Lees ${ }^{8}$, Damian Lodowski, Martin Pearce ${ }^{9}$, Danuta Peryt ${ }^{10}$, Bradley B. Sageman ${ }^{11}$, Poul Schiøler ${ }^{12}$, Jordan Todes ${ }^{1,13}$, David Uličný ${ }^{14,15}$, Silke Voigt ${ }^{16}$, Frank Wiese ${ }^{17,18}$, With contributions by Christian Linnert ${ }^{19}$, Tobias Püttmann ${ }^{20}$, and Seiichi Toshimitsu ${ }^{21}$

\title{
The Global Boundary Stratotype Section and Point (GSSP) for the base of the Coniacian Stage (Salzgitter-Salder, Germany) and its auxiliary sections (Słupia Nadbrzeżna, central Poland; Stř̌eleč, Czech Republic; and El Rosario, NE Mexico)
}

\author{
${ }^{1}$ Faculty of Geology, University of Warsaw, Al. Żwirki i Wigury 93, 02-089 Warszawa, Poland; *Corresponding author, \\ E-mail: i.walaszczyk@uw.edu.pl \\ ${ }^{2}$ Czech Geological Survey, Klárov 3/131, 11821 Praha 1, Czech Republic \\ ${ }^{3}$ School of Geography, Environment and Earth Sciences, Victoria University of Wellington, PO Box 600, Wellington 6140, New Zealand \\ ${ }^{4}$ SNSB Jura-Museum, Willbaldsburg, Burgstr. 19, 85072 Eichstätt, Germany \\ ${ }^{5}$ Department of Geography, Geology and the Environment, Kingston University London, Kingston upon Thames KT1 2EE, UK \\ ${ }^{6}$ Museum of Natural History, Oxford University, Parks Road, Oxford OX1 3PW, UK \\ ${ }^{7}$ Department of Earth Sciences, Oxford University, South Parks Road, Oxford OX1 3AN, UK \\ ${ }^{8}$ Department of Earth Sciences, University College London, Gower Street, London WC1E 6BT, UK \\ ${ }^{9}$ Evolution Applied Limited, 33 Gainsborough Drive, Sherborne, Dorset DT9 6DS, United Kingdom \\ ${ }^{10}$ Institute of Paleobiology, Polish Academy of Sciences, Twarda 51/55, 00-818 Warszawa, Poland \\ ${ }^{11}$ Department of Earth and Planetary Sciences, Northwestern University, 2145 Sheridan Avenue, 60201 Evanston, Illinois, USA \\ ${ }^{12}$ MGPalaeo, Unit 1/5, Arvida Street, Malaga, WA 6090, Australia \\ ${ }^{13}$ Department of Geophysical Sciences, University of Chicago, 5734 South Ellis Avenue, 60637 Chicago, Illinois, USA \\ ${ }^{14}$ Institute of Geophysics, Czech Academy of Sciences, Boční II/1401, 14131 Praha 4, Czech Republic \\ ${ }^{15}$ Institute of Geology and Paleontology, Faculty of Science, Charles University, Albertov 6, 12843 Praha 2, Czech Republic \\ ${ }^{16}$ Institute of Geosciences, Goethe University Frankfurt, Altenhöferallee 1, 60438 Frankfurt, Germany \\ ${ }^{17}$ Department of Geobiology, Geoscience Centre, Georg-August-Universität Göttingen, Germany \\ ${ }^{18}$ Institute of Earth Sciences, Heidelberg University, Im Neuenheimer Feld 234-236, 69120 Heidelberg, Germany \\ ${ }^{19}$ Vogelstraße 6a, 44869 Bochum, Germany \\ ${ }^{20}$ Institute of Geology, Mineralogy and Geophysics, Ruhr University Bochum, 44780 Bochum, Germany \\ ${ }^{21}$ Geological Survey of Japan, AIST, 1-1-1 Higashi, Tsukuba, Ibaraki 305-8567, Japan
}

(Received: July 7, 2021; Revised accepted: August 2, 2021)

https://doi.org/10.18814/epiiugs/2021/021022

Following votes in the Coniacian Working Group, the Cretaceous Subcommission and the International Commission on Stratigraphy, on May $1^{\text {st }}$, 2021, the International Union of Geological Sciences voted unanimously to ratify the Global Stratotype Section and Point (GSSP) proposal for the base of the Coniacian Stage of the Upper Cretaceous Series and Cretaceous System. The lower boundary of the Coniacian Stage is placed at the base of Bed 46 of the Salzgitter-Salder section in northern Germany. The boundary is defined by the first appearance of the inoceramid bivalve species Cremnoceramus deformis erectus (Meek) and complemented by the Navigation carbon isotope event. Additional data include the bivalve genus Didymotis, foraminifera, ammonite, nannofossil and organic-walled dinoflagellate cyst events. Three auxiliary sections (Shupia Nadbrzeżna, central Poland; Střeleč, Czech Republic; El Rosario, NE Mexico) supplement the details of the boundary record in various facies, and in differing geographic and biogeographic contexts.

\section{Introduction}

The Salzgitter-Salder quarry section was proposed as the primary candidate for the Global Boundary Stratotype Section and Point (GSSP) of the base of the Coniacian Stage during the Second International Symposium on Cretaceous Stage Boundaries in Brussels (Sep- 
tember 8-16, 1995; Kauffman et al., 1996). In the recommendation of the Coniacian Working Group of the Subcommission on Cretaceous Stratigraphy (then chaired by Professor Erle Kauffman), the Turonian-Coniacian boundary was defined at the first appearance datum (FAD) of the inoceramid bivalve Cremnoceramus rotundatus (sensu Tröger non Fiege), which was subsequently synonymised with Cremnoceramus deformis erectus (Meek) (see Walaszczyk and Cobban, 1998, 2000; Walaszczyk and Wood, 1998). In Salzgitter-Salder, this level was recognized at the base of limestone Bed 47, as defined following Wood et al. (1984). Despite certain disadvantages - namely, diagenetic alteration of the carbonates and the paucity of ammonites - the SalzgitterSalder section is a continuous, well-exposed, richly fossiliferous succession without any obvious hiatuses, which satisfied the requirements for a stratotype section at the time (Kauffman et al., 1996).

However, subsequent studies of the Salzgitter-Salder section suggested the presence of at least two small hiatuses within the boundary interval: (i) below Bed 45 and (ii) immediately below the base of the Coniacian (Walaszczyk and Wood, 1998; Wood et al., 2004). The latter was independently confirmed by comparison of the stable carbon isotope curve from Salzgitter-Salder with the curve from the expanded Liencres section in northern Spain (Wiese, 1999). The apparently missing intervals were documented in Słupia Nadbrzeżna (central Poland), another section put forward as a potential stratotype section during the Brussels symposium (Kauffman et al., 1996). Although the Słupia Nadbrzeżna section - in the cliffs of the Vistula River - is more complete across the boundary interval (Walaszczyk, 1992; Walaszczyk and Wood, 1998; Wood et al., 2004), possesses an excellent inoceramid record, and has yielded the ammonite Forresteria (Harleites) petrocoriensis (Coquand), an auxiliary marker for the basal Coniacian that is absent in Salzgitter-Salder (see, Kennedy and Walaszczyk, 2004), the poor quality of the exposure disqualified it as an independent candidate for the basal boundary stratotype. Consequently, a composite Coniacian basal boundary stratotype section, composed of the Salgzitter-Salder and the Słupia Nadbrzeżna sections, was developed (Walaszczyk et al., 2010). The idea was first introduced by I. Walaszczyk and C.J. Wood during the Cretaceous Subcommission meeting accompanying the 7th International Symposium on the Cretaceous at Neuchâtel, Switzerland, in September 2005, and subsequently at the Stratigraphic Commission and Subcommission meeting at the 33rd Geological Congress in Oslo in 2008 (Walaszczyk and Wood, 2008), at which it was particularly well-received; it was also presented by C.J. Wood during the 8th International Symposium on the Cretaceous in Plymouth, United Kingdom, September 2008. Subsequent discussion among the Coniacian Working Group led to the general consensus that the composite Salgzitter-Salder - Słupia Nadbrzeżna section was the best proposal. Walaszczyk et al. (2010) was intended as an initial report, to be followed shortly thereafter by a formal submission to the Cretaceous Subcommission.

Delays in the preparation and submission of the stratotype proposal coincided with a significant change to the GSSP proposal process - the return to a single-section stratotype requirement, and therefore the presumptive rejection of a composite stratotype proposal. As a result, the submission was suspended, and because of the hiatuses interpreted in the Salzgitter-Salder succession, a search for alternative GSSP candidates resumed. Among the newly studied sections were El Rosario (Sierra del Carmen National Park, Coahuila, Mex- ico; Ifrim et al., 2014; see also Ifrim et al., 2019) and Hot Springs (Big Bend National Park, Texas, USA; Cooper et al., 2015, 2017). Additionally, several localities previously proposed during the Brussels Symposium (Kauffman et al., 1996) were reconsidered, including Pueblo (Colorado, USA) and Wagon Mound (New Mexico, USA) (see, Walaszczyk et al., 2012, 2014b). However, each of the newly proposed or restudied localities had significant issues, and none appeared superior to the Salzgitter-Salder section.

A new approach - which required the selection of a main singlesection stratotype, supplemented by auxiliary sections to better define the range of variability associated with the boundary interval - was discussed during the Subcommission Meeting at the 10th International Symposium on the Cretaceous in Vienna in 2017. Furthermore, Silke Voigt presented an updated, high-resolution carbon isotope chemostratigraphy for Salzgitter-Salder and its possible correlation with Słupia Nadbrzeżna, which suggested that the hiatus at the base of the C. deformis erectus Zone (basal Coniacian) was much smaller than previously interpreted, or even non-existent - that is, the basal Coniacian in Salzgitter-Salder was continuous (Voigt et al., 2021). Finally, new inoceramid collections from the boundary interval showed that C. deformis erectus (Meek), the boundary marker, first appears slightly lower than previously documented (already in Bed 46 instead of Bed 47), which made the correlation to the Słupia Nadbrzeżna succession straightforward (here and in Voigt et al., 2021). With this new framework, no further obstacles existed to formally propose the SalzgitterSalder quarry section as the GSSP of the Coniacian Stage. The proposal was accepted by the Coniacian Working Group, the Cretaceous Subcommission and the International Commission on Stratigraphy, and ratified by the International Union of Geological Sciences. Consequently, the Salzgitter-Salder section is designated the GSSP for the base of the Coniacian, with the lower boundary of the stage placed at the base of Bed 46 of the succession and defined by the evolutionary first appearance of the inoceramid bivalve species $C$. deformis erectus. Three auxiliary sections (Słupia Nadbrzeżna, central Poland; Střeleč railway cutting, Czech Republic; El Rosario, NE Mexico), supplement the details of the boundary record in various facies, and in differing geographic and biogeographic contexts.

\section{Definition of the Base of the Coniacian}

\section{Historical}

Coquand (1857) introduced the Coniacian as the lowest division of the Senonian Stage of d'Orbigny (1843), based on the sequences in the environs of Cognac, Charente (Aquitaine, France) (Kennedy, 1983, 1984a, b). The standard zonal subdivision was based on ammonites, and its base was defined by the first occurrence of Barroisiceras haberfellneri (de Grossouvre non Hauer) (Séronie-Vivien, 1972, 1980). The species was later shown to be Forresteria (Harleites) petrocoriensis (Coquand) (Kennedy, 1984a, b), and the eponymous zone was regarded as the standard ammonite zone for the base of the Coniacian Stage. However, the boundary between the Coniacian and the underlying Turonian in the type Coniacian is marked by a prominent discontinuity surface (Kennedy, 1984a), so the French succession cannot be regarded as a potential candidate for the boundary stratotype. Further- 
more, $F$. $(H$.) petrocoriensis has subsequently been documented in the region from the underlying Turonian (Diebold et al., 2010).

\section{Primary Marker}

Of the three boundary criteria discussed during the Brussels symposium - (1) the First Appearance Datum (FAD) of the ammonite $F$. (H.) petrocoriensis [Note: we use the terms Lowest Occurrence and Highest Occurrence (with acronyms LO and HO respectively) for denoting records of taxa in a specific section, and First Appearance Datum and Last Appearance Datum (with acronyms FAD and LAD respectively), for denoting an evolutionary appearance / disappearance date of a taxon]; (2) the FAD of the inoceramid Cremnoceramus deformis (Meek) and / or C. schloenbachi (Boehm); and (3) the FAD of Cremnoceramus rotundatus (sensu Tröger non Fiege) - the one recommended by the Working Group was the FAD of C. rotundatus (sensu Tröger non Fiege). This taxon was later shown to be a junior synonym of the American species Cremnoceramus erectus (Meek). The species was then interpreted as the oldest chronosubspecies of the lineage of $C$. deformis, and consequently referred to as $C$. deformis erectus (Meek) (see Walaszczyk and Wood, 1998; Walaszczyk and Cobban, 1998, 2000). This taxon has been generally accepted as the basal boundary biostratigraphic marker, with the noted exception of Sikora et al. (2004).

However, the understanding of the Working Group in Brussels that the FAD of $C$. rotundatus lies between the LAD of the uppermost Turonian ammonite Prionocyclus germari (Reuss) and the FAD of $F$. (H.) petrocoriensis, the classic ammonite marker of the base of the Coniacian (Kauffman et al., 1996), is nowadays considered invalid, following detailed, high-resolution studies of ammonite biostratigraphy in the Turonian-Coniacian boundary interval. As shown by Walaszczyk and Cobban (1998, 2000; see also Cobban et al., 2006), the FAD of $C$. deformis erectus is well above the FAD of Forresteria (Forresteria) peruana (Brüggen), regarded as an approximate stratigraphic equivalent to the European $F$. $(H$.) petrocoriensis, in the Western Interior Basin, USA. In Słupia Nadbrzeżna, central Poland (Kennedy and Walaszczyk, 2004), and the Aquitaine Basin of southwestern France (Diebold et al., 2010), F. (H.) petrocoriensis has now been reported from the topmost upper Turonian Mytiloides scupini inoceramid Zone, well below the FAD of $C$. deformis erectus.

A considerable advantage of $C$. deformis erectus as the primary boundary marker stems from its relatively wide geographic range and, especially, from its well-documented evolutionary history. The taxon resulted from a clearly recorded cladogenetic split in the Cremnoceramus waltersdorfensis lineage that is a palpable evolutionary event presumed to be isochronous in the stratigraphic record (Walaszczyk and Wood, 1998). Although the base of the waltersdorfensis lineage marks the main turnover event in inoceramid faunas in the boundary interval (the change from the Mytiloides-dominated late Turonian fauna to the latest Turonian - early Coniacian Cremnoceramus-dominated fauna), the nature of the $\mathrm{LO}$ of $C$. waltersdorfensis is unclear and consequently unsuitable as the boundary criterion. Indeed, present records could either suggest that $C$. waltersdorfensis evolved in situ, or that the first appearance of the genus Cremnoceramus in the Euramerican Biogeographic Region reflects a large-scale immigration / invasion event (see further discussion below).

\section{Secondary Markers}

\section{Ammonites}

Forresteria $(H$.) petrocoriensis, the classic ammonite marker of the base of the Coniacian (Kennedy, 1984a), first appears in the topmost part of the upper Turonian M. scupini Zone (Kennedy and Walaszczyk, 2004; Diebold et al., 2010; Diebold, 2012), although it should be noted that it does not occur commonly until the basal Cremnoceramus crassus inconstans Zone of the lower Coniacian (Kaplan and Kennedy, 1994). The taxon is well recognized within the European Biogeographic Province; records from beyond this region require further study. In the North American Western Interior, an equivalent level is marked by the LO of $F$. (F.) peruana (see, e.g., Walaszczyk and Cobban, 2000). Slightly higher, in a level regarded coeval with the FAD of $C$. deformis erectus, Scaphites preventricosus Meek and Hayden first appears (see Cobban, 1994; also Kennedy and Cobban, 1991; Walaszczyk and Cobban, 2000). In northeastern Mexico the boundary seems to be wellapproximated by the LO of Schlueterella stinnesbecki Ifrim (see Ifrim et al., 2019). In the East African Biogeographic Province/Subprovince (sensu Kauffman, 1973) the ammonite markers of the basal Coniacian are Kossmaticeras (Kossmaticeras) theobaldianum (Stoliczka) and Barroisiceras onilahyense (Basse) (Kennedy and Klinger, 1975; Kennedy, 1978; Walaszczyk et al., 2004, 2014a, 2018; Gale et al., 2019).

\section{Didymotis bivalves}

Although poorly understood at the species level and in its evolutionary context (see e.g., Andrade, 2005), the genus Didymotis is a very useful marker of the Turonian-Coniacian boundary interval within the Euramerican Biogeographic Region. The genus is regularly present from the middle $M$. scupini Zone of the upper Turonian, up to the C. deformis erectus Zone of the basal lower Coniacian (e.g., Wood et al., 1984; Walaszczyk, 1992; Wiese and Kröger, 1998; Walaszczyk, 2000; Seeling and Bengtson, 2003; Čech and Uličný, 2021), with a series of distinct successive morphotypes (Wood et al., 1984; Wiese, 1997; Čech and Uličný, 2021). The stratigraphically youngest record comes from the C. deformis deformis / C. crassus crassus inoceramid Zone of the Březno section in Bohemia (see, Čech and Švábenická, 1992).

In the boundary interval there are two acme occurrences of the genus, referred to as the Didymotis I and II events; the latter is located within the $C$. waltersdorfensis waltersdorfensis inoceramid Zone immediately preceding the entry of $C$. deformis erectus, the primary marker of the basal Coniacian. As is demonstrated in the Hot Springs succession (Big Bend National Park, Texas) (Cooper et al., 2017; Walaszczyk, unpublished data), Didymotis may have had a more continuous range in the southerly extent of the Euramerican Biogeographic Region, and appeared in areas to the north only during short intervals. As such, the Didymotis events can be interpreted as ecological invasion events; the consistent pattern of Didymotis acme events within and between biozones suggests they are potentially isochronous.

\section{Planktonic foraminifera}

The best planktonic foraminifera boundary marker for the base of the Coniacian Stage is the FAD of Dicarinella concavata (Brotzen). 
Traditionally, the Turonian-Coniacian boundary is placed in the lowermost part of the $D$. concavata Zone (Robaszynski et al., 1990; Premoli Silva and Sliter, 1995; Robaszynski and Caron, 1995; Ogg et al., 2004). Its lowest appearance, marking the base of the eponymous zone, is recognized in the uppermost part of the M. scupini inoceramid Zone. The event was not recognized in Salzgitter-Salder; however, it is well documented in the El Rosario and Słupia Nadbrzeżna successions, two of the auxiliary sections proposed here for the base of the Coniacian Stage. The LO can easily be projected onto the stratotype section of Salzgitter-Salder.

Recently, the last occurrence of the heterohelicid species Huberella huberi Georgescu was proposed as a good indicator of the TuronianConiacian boundary (Georgescu et al., 2011). This species was recognized as possessing a very short stratigraphic range (the upper part of the Marginotruncana schneegansi foraminiferan Zone and the lowermost part of the D. concavata Zone of Robaszynski and Caron (1995) (Huber et al., 2017; Georgescu, 2017), and it has been reported from the Caribbean region and the central Atlantic, equatorial Pacific (Georgescu, 2007; Georgescu et al., 2011), and Indian Oceans (Haynes et al., 2015; Huber et al., 2017). However, Petrizzo et al. (2017) reported a highest occurrence of $H$. huberi in the lowermost part of the Dicarinella asymetrica Zone, in the middle part of the calcareous nannoplankton UC10 Zone (middle Coniacian) in southern Tanzania. The species is unrecorded from the Salzgitter-Salder section. Recent study of planktonic foraminifera in the Turonian-Coniacian boundary interval of the El Rosario succession (Peryt, this paper) confirms that $H$. huberi is present above the Turonian-Coniacian boundary as defined by the lowest occurrence of the inoceramid $C$. deformis erectus. The highest occurrence is here recorded in the lower Coniacian, at the boundary between the inoceramid $C$. crassus dobrogensis and $C$. crassus inconstans zones, or just at the base of the ammonoid $F$. (F.) alluaudi Zone (this paper).

Pseudotextularia nuttali (Voorwijk) is another heterohelicid species which has been used as a proxy for the Turonian-Coniacian boundary. Nederbragt (1990) proposed the P. nuttali Zone and Robaszynski and Caron (1995) correlated it with the Coniacian part of the D. concavata Zone, inferring its base to correspond to the Turonian-Coniacian boundary. Subsequently, however, Haynes et al. (2015) demonstrated that $P$. nuttali evolved, from Planoheterohelix praenuttali, later, in the late Coniacian, within the $D$. concavata Zone. Similarly, Petrizzo et al. (2017) recorded the first appearance of $P$. nuttali in the upper part of the $D$. concavata Zone, in a part of the succession dated as calcareous nannoplankton Zone UC10, roughly corresponding to the middleupper Coniacian. Consequently, it seems that the FAD of $P$. nuttali is stratigraphically distinctly younger than the Turonian-Coniacian boundary interval, which explains the absence of this species in all of the sections studied herein.

\section{Benthic foraminifera}

The most promising benthic foraminiferal events for the recognition of the base of the Coniacian are: (1) the FAD of Protostensioeina sp. 2, which results from an anagenetic transition within the Protostensioeina lineage; (2) the FAD of Globorotalites michelinianus (d'Orbigny), which appeared as a result of an anagenetic transition from Globorotalites multiseptus (Brotzen); and (3) the FAD of Gavelinella praeinfrasantonica (Vasilenko and Myatliyuk), which appeared as a result of an anagenetic transition from Gavelinella vesca (Bykova). In addition, (4) the FAD of Gavelinella lorneiana (d'Orbigny), which resulted from an anagenetic transition within the G. ammonoides (Reuss) $-G$. lorneiana lineage, has some potential as a boundary marker.

\section{Carbon isotopes}

The top of the newly revised Navigation Carbon Isotope Event (CIE) (Jarvis et al., 2006; Voigt et al., 2021), which extends from a horizon in the topmost $M$. scupini Zone to the $C$. waltersdorfensis waltersdorfensis Zone [spanning from Bed 42 (option 1) or Bed 39b (option 2) to the middle of Bed 46 in Salzgitter-Salder] is an excellent proxy for the base of the Coniacian Stage. Within the high-resolution carbon isotope chemostratigraphy of Salzgitter-Salder, the top of the Navigation CIE matches the old single-point definition of stage-boundary $\delta^{13} \mathrm{C}$ minimum proposed by Voigt and Hilbrecht (1997). The Navigation CIE coincides with a general inflection point in the long-term Upper Cretaceous stable carbon isotope curve (Jarvis et al., 2006, 2015): $\delta^{13} \mathrm{C}$ values generally decrease through the upper Turonian, and increase above the Navigation CIE through the majority of the lower to middle Coniacian.

\section{The GSSP for the Base of the Coniacian Stage: Salzgitter-Salder Section}

\section{Location}

The Salzgitter-Salder quarry (Lower Saxony, Germany; Figs. 1-4) is located in the NW-SE oriented Lower Saxony Basin - that is, the marginal western part of the Central European Basin System (see, Scheck-Wenderoth et al., 2008). The evolution of the basin was terminated during a regional Late Cretaceous-Paleogene uplift. Biogeographically, the entire Central European Basin belonged to the North European Province, the eastern part of the Euramerican Biogeographic Region (Fig. 1), which ranged from the western tip of Asia through Europe and the North American Atlantic and Gulf Coasts to the North American Western Interior Basins (biogeographic subdivision following Kauffman, 1973).

The quarry is located south of the A39 motorway between the town of Braunschweig and the Autobahn junction 'Salzgitter' (geographic coordinates: $52.1243^{\circ} \mathrm{N}, 10.3295^{\circ} \mathrm{E}$ ), near the exit to the town of Salzgitter-Salder (Fig. 2B). The quarry is situated in the southern, steeply north-northeastward dipping (c. $70^{\circ}$ ) flank of the asymmetrical Lesse Syncline, adjacent to the Salzgitter-Lichtenberg structure (Fig. 3). The asymmetry of the Lesse Syncline resulted from halokinetic movements of the Broistedt structure (salt-diapir) and contemporaneous uplift of the Salzgitter-Lichtenberg structure (Baldschuhn and Kockel, 1998).

\section{Protection of the Site}

The Salzgitter-Salder quarry is owned by the Stiftung Naturlandschaft, and is a part of the UNESCO Geopark "Harz-Braunschweiger Land-Ostfalen". The site is in the direct care of the Bund für Umwelt und Naturschutz Deutschland (BUND) in Salzgitter. Thanks to Prof. Jochen Erbacher (Landesamt für Bergbau, Energie und Geologie, 


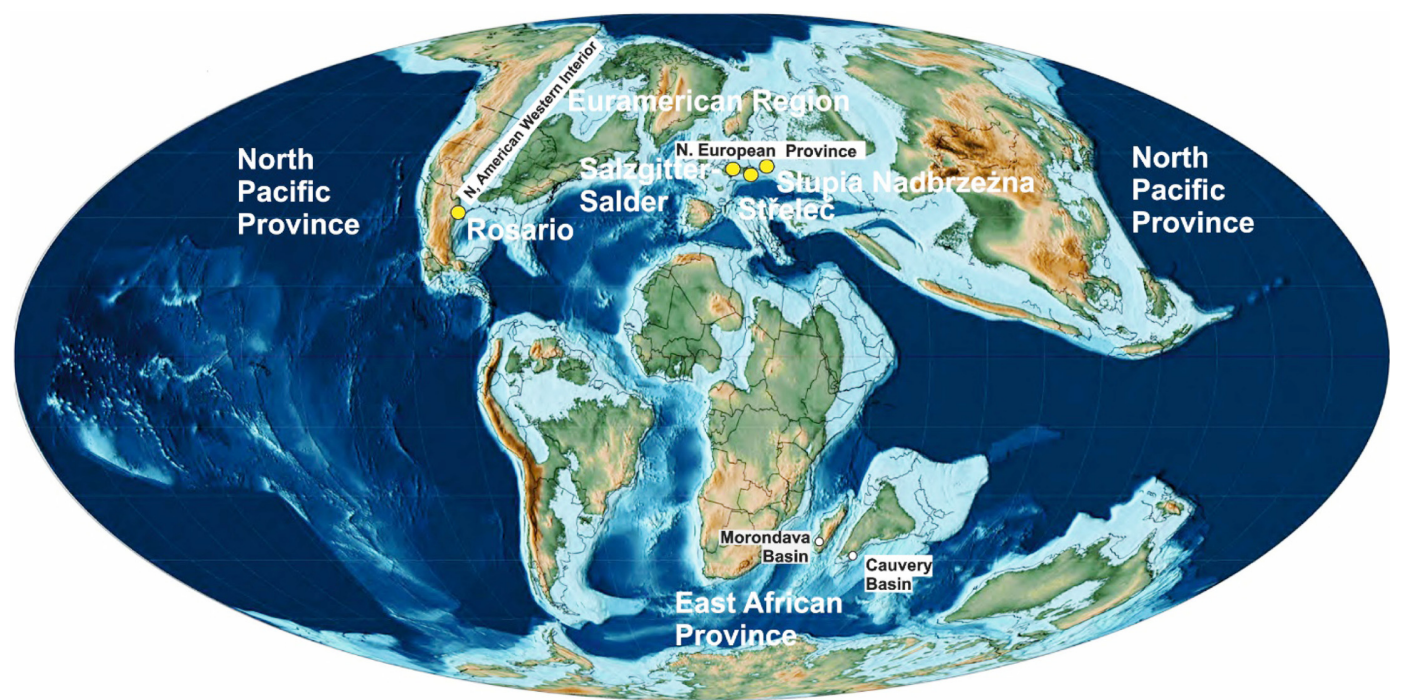

Figure 1. Key localities and palaeobiogeographic regions discussed in the text shown on a palaeogeographic map of the Coniacian-Santonian interval. After Scotese (2002).

Hannover, Lower Saxony), the protection and adequate maintenance of the GSSP locality was included in the plans of the UNESCO Geopark. We have the full support of Dr. Henning Zellmer, the manager of the Geopark. The necessary funding and cleaning of the site (with an excavator, if necessary) will be arranged.

\section{The Turonian-Coniacian Succession}

The Salzgitter-Salder section (Figs. 2C, D; 4) exposes a c. $220 \mathrm{~m}$ thick middle Turonian-lower Coniacian succession of well-bedded carbonates belonging to the Söhlde, Salder, and Erwitte formations
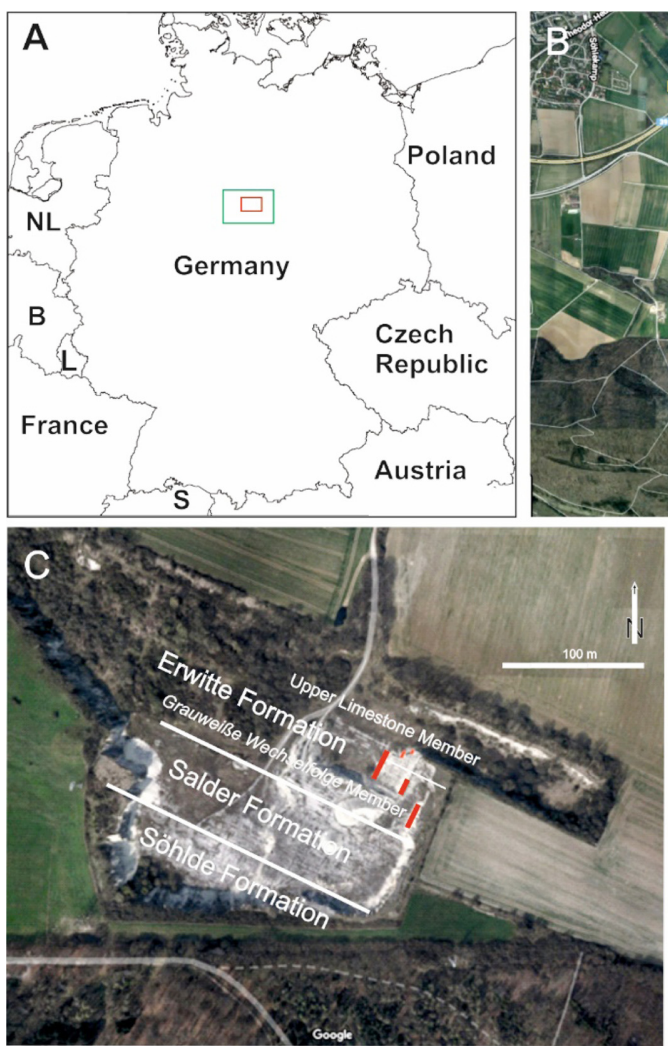
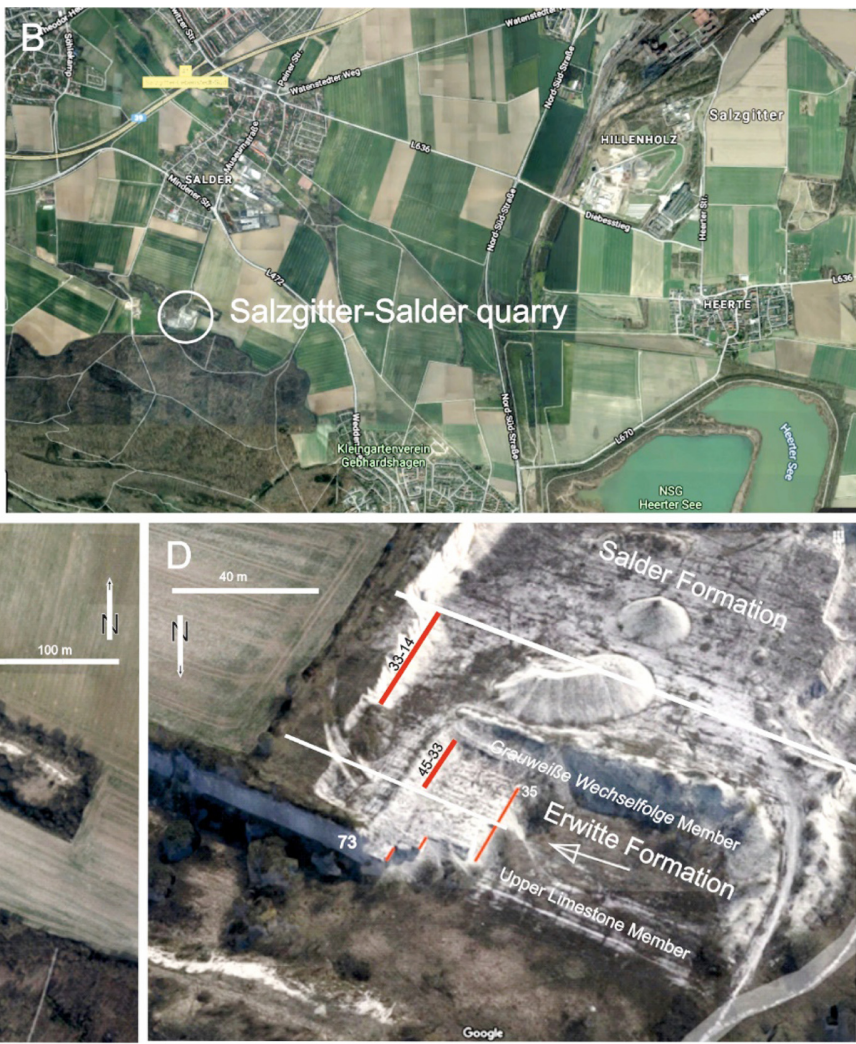

Figure 2. Location and Google Earth map views of Salzgitter-Salder quarry. (A) Outline map of Germany and adjacent countries, to show the location of the Salzgitter-Salder area (red rectangle); the green rectangle indicates the position of the geological map from Fig. 3, which covers eastern Lower Saxony, where Salzgitter-Salder quarry is located. (B) Locality map of Salzgitter-Salder quarry. (C) North-oriented view of the entire quarry with the studied Turonian-Coniacian boundary succession marked with red lines; the beds run WNW-ESE with a dip c. $70^{\circ}$ to the NNE. (D) South-oriented view of the quarry showing its NE part with the boundary succession; the arrow shows the orientation of photographs from Figure 4; the numbers are bed numbers of the succession (see Figs. 5, 7, 10-12 for the geological log of the succession). 


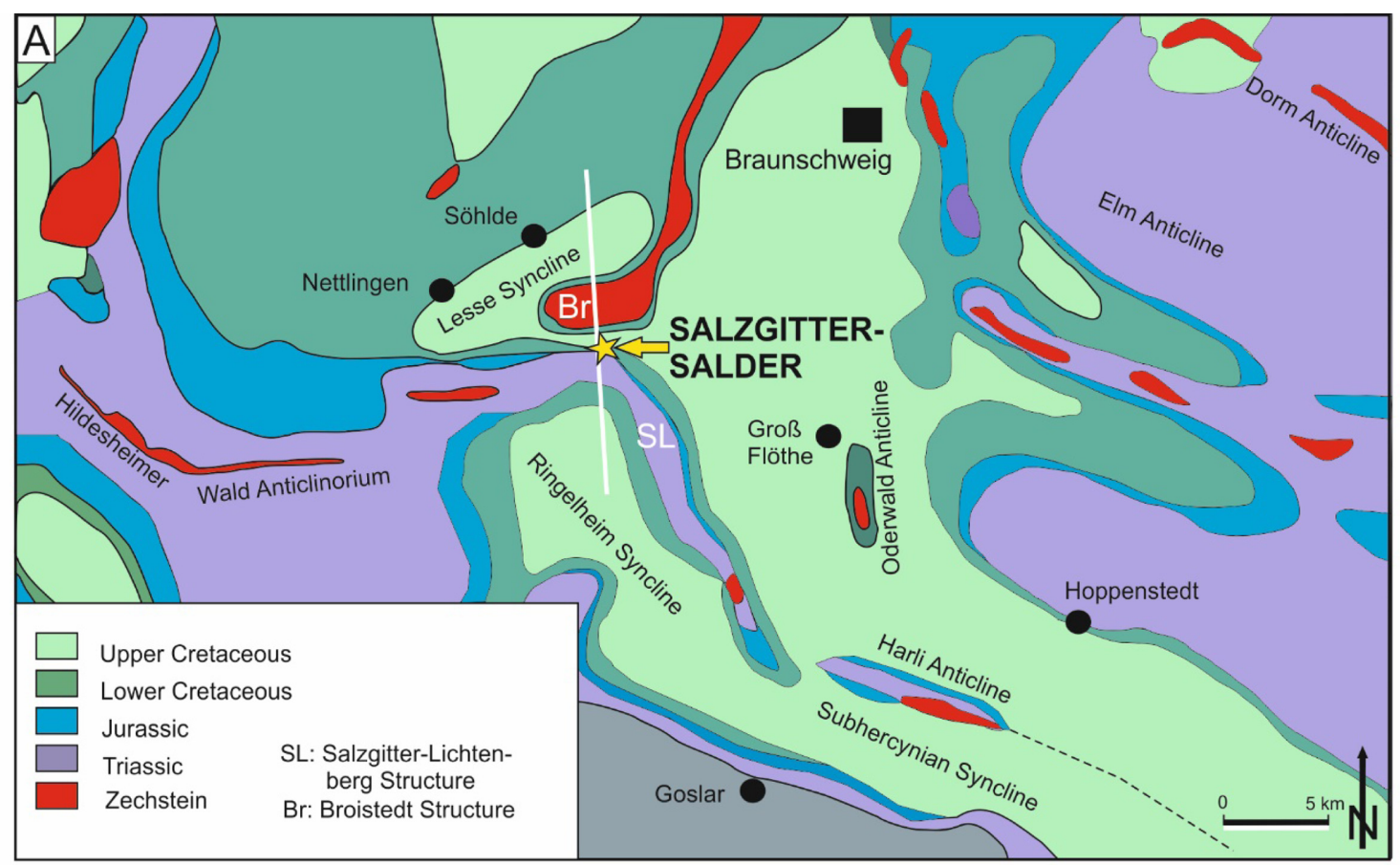

B Br: Broistedt Structure

SALZGITTER-

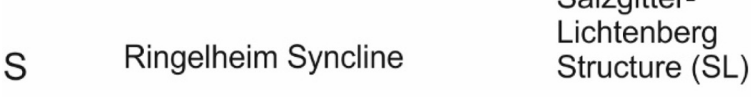

SALDER

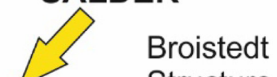

Structure $(\mathrm{Br})$

Lesse Syncline

N

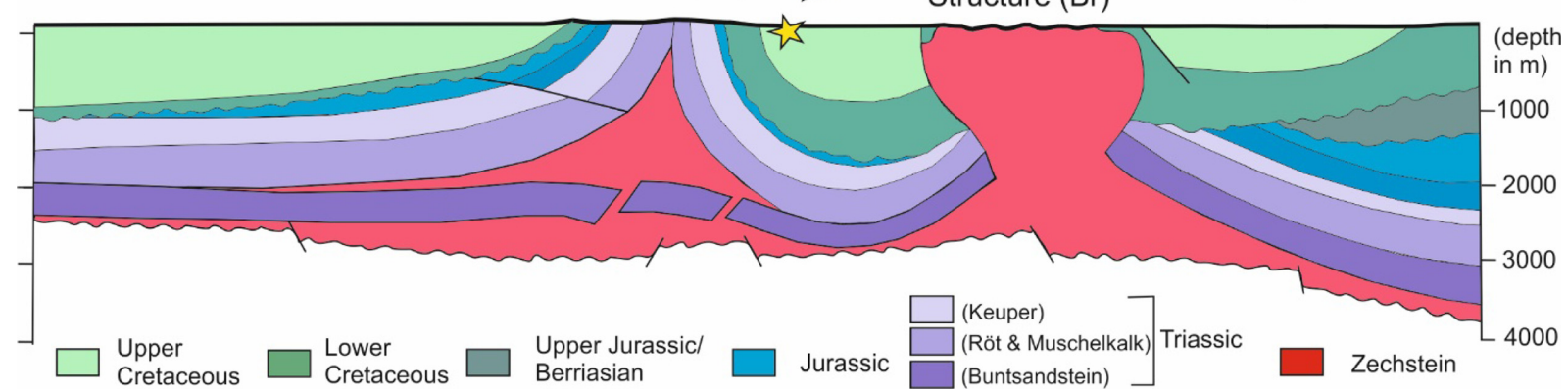

Figure 3. Geology of the Salzgitter-Salder area. (A) Simplified geological sketch-map of eastern Lower Saxony, between Hannover to the west, Braunschweig to the north and Goslar to the south (detail of the Geologische Übersichtskarte der BRD - GÜK 500, CC 3926 Braunschweig and CC 4726 Goslar). Location of the Salzgitter-Salder quarry section is marked with a yellow star; the white line indicates the position of the geological cross section. (B) Geological, $N-S$ oriented cross-section across the Lesse Syncline - Salzgitter-Lichtenberg Structure and Ringelheim Syncline (modified after Baldschuhn and Kockel 1998).

(see, Niebuhr et al., 2007; Wiese, 2009). The last of these comprises of the Grauweiße Wechselfolge (Grey and White Alteration) Member succeeded by the Upper Limestone Member (Wood et al., 1984; Ernst and Wood, 1995; Wood and Ernst, 1998; see Niebuhr et al., 2007; Wiese, 2009). The Turonian-Coniacian boundary interval constitutes the upper part of the Grauweiße Wechselfolge and its turnover to the Upper Limestone Member. The succession is additionally subdivided by numerous litho-, tephro- and eco-events, several of which have supra-regional correlation potential. The discussion in this report will generally focus on the inoceramid-dominated fossil-rich interval, ranging from Bed 35 up to Bed 73, although some data are limited to a narrower interval or extended slightly below the interval of interest (Figs. 4, 5). There is no physical evidence of unconformities in the succession; however, two small hiatuses / condensations have been suggested (Wood et al., 2004; Walaszczyk and Wood, 2008) at the top of Bed 44 and within Bed 46, respectively, based on correlation to the Słupia Nadbrzeżna section.

Although the state of the exposure at Salzgitter-Salder is gradually deteriorating (compare illustrations in Fig. 4), it still offers easy access to the continuous boundary interval. Moreover, improving the state of a part of the quarry with the Turonian-Coniacian boundary succession and subsequent maintenance is included in the plans of the UNESCO Geopark, Harz-Braunschweiger Land. Ostfalen, which encompasses the area of the quarry.

Detailed descriptions of the boundary interval have been previously provided in Wood et al. (1984), Kauffman et al. (1996, p. 92 and figs. 3-5), Walaszczyk and Wood (1998), and Wood et al. (2004), and are summarized below. In addition, new observations by Čech (in Čech and Uličný, 2021), Voigt et al. (2021) and Walaszczyk (unpublished) are included. The following beds yielded biostratigraphically significant macrofauna and bioevents (see also Fig. 5): 

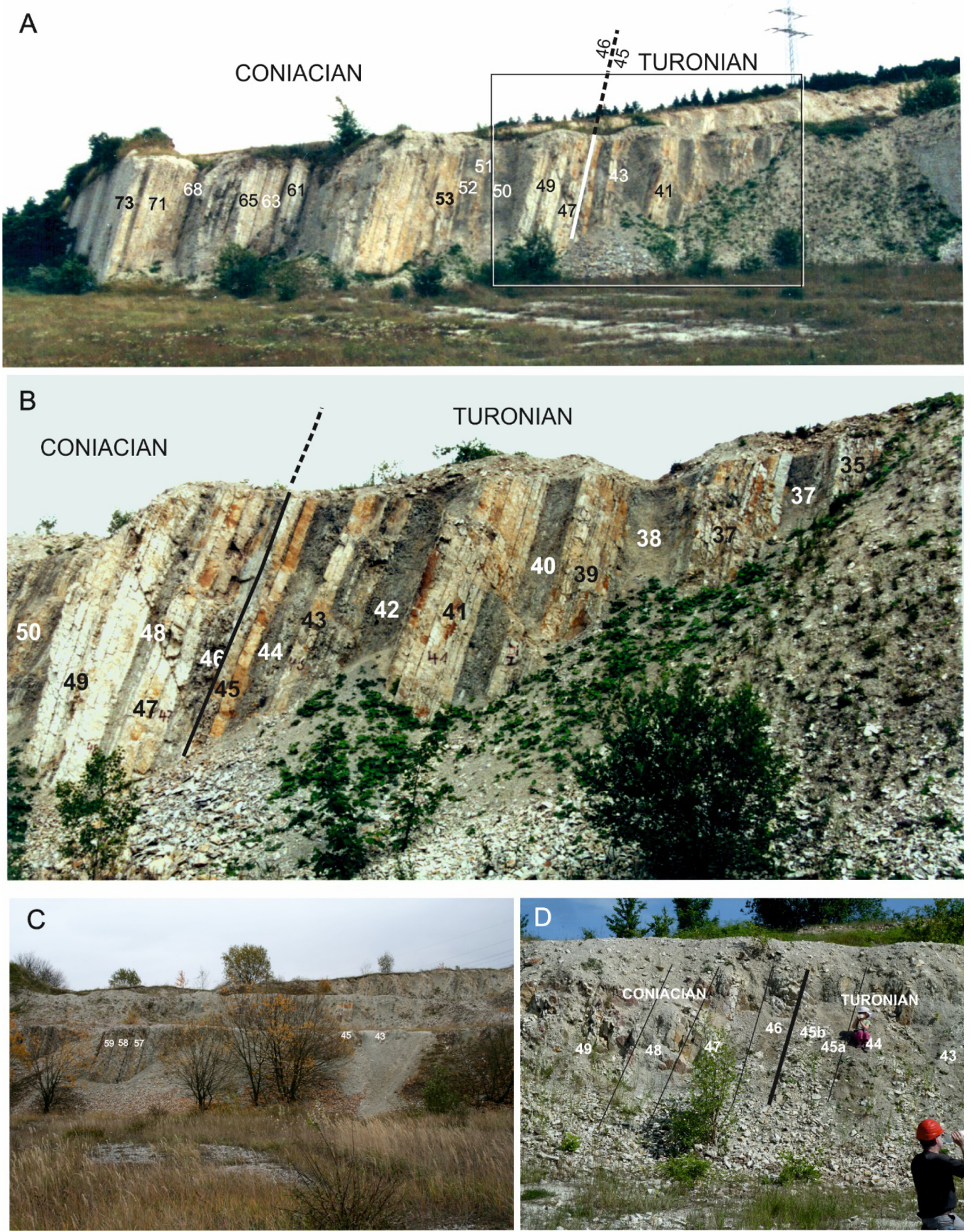

Figure 4. Turonian-Coniacian boundary succession in the Salzgitter-Salder quarry. (A-B) General view of the eastern wall of the quarry in 2001; selected bed numbers for orientation (see Figs. 5, 7, 10-12 with geological logs for detailed stratigraphy). (C-D) State of the boundary interval in 2012 (D) and in $2016(C)$. While the quality of the exposure has decayed over time, it is still easily possible to access and sample the boundary interval (C - photo by Stanislav Čech, D - photo by Christina Ifrim).

Bed 39b (limestone bed): characterized by a flood occurrence of weakly ornamented forms of the thin-shelled bivalve Didymotis (Didymotis I Event of Wood et al., 1984; Walaszczyk and Wood, 1998; Walaszczyk et al., 2010), associated with a M. scupini Zone inoceramid assemblage, comprising Mytiloides herbichi (Atabekian), M. scupini, and Inoceramus lusatiae Andert. The Didymotis I morphotype exhibits a simple sculpture of commarginal thick, rounded rugae with relatively wide interspaces; the radial elements of the Didymotis II morphotype are absent or extremely rare.

Bed 41a (limestone bed): rare Didymotis with radial ribs (reported by S. Čech).

Bed 41c (limestone bed): same M. scupini inoceramid zonal assem- 


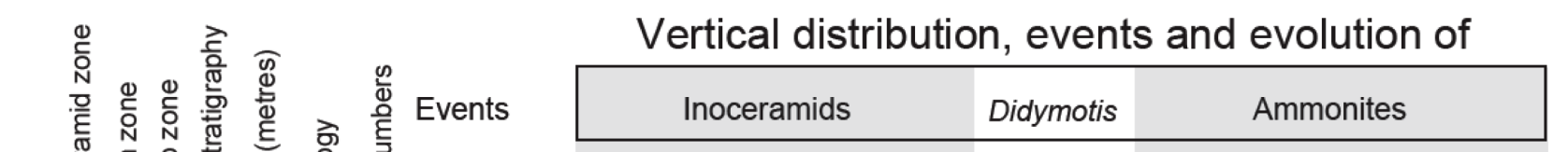

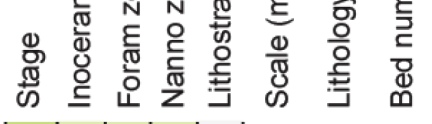

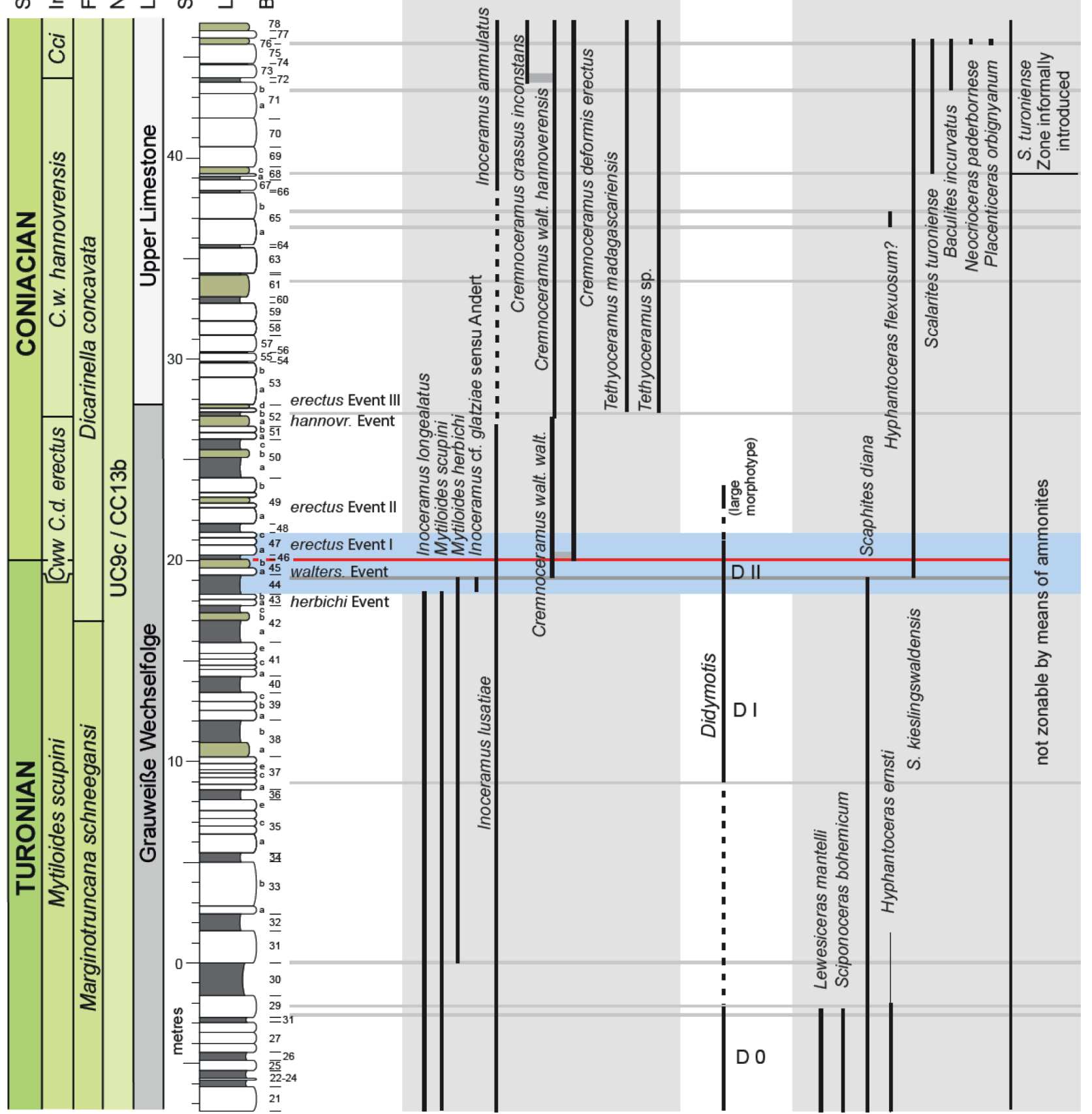

Figure 5. Ranges of inoceramids, Didymotis bivalves and ammonites in the Salzgitter-Salder section (Didymotis range partly after Čech and Uličný 2021); Cww - Cremnoceramus waltersdorfensis waltersdorfensis; Cci-Cremnoceramus crassus inconstans. Bed numbers and the lithological log (as also in Figures 7, 10-12) are redrawn from Raseman (1984) and Wood et al. (1984). Blue horizontal band indicates the interval of major macrofaunal turnover across the stage boundary.

blage as in Bed 39b (Didymotis I Event), but with no records of Didymotis reported to date.

Bed 42c (marly bed): horizon of common M. herbichi.

Bed 43a (middle and top parts of the limestone bed): characterized by a flood occurrence of $M$. herbichi, herein designated as a distinctive herbichi Event. This bed has also yielded rare specimens of Didy- motis.

Bed 44 ( $0.95 \mathrm{~m}$ thick conspicuous marl bed): the highest $15 \mathrm{~cm}$ of this bed contains a flood occurrence of largely compressed, albeit well-preserved, inoceramids of uncertain affinity, representing a new and biostratigraphically significant assemblage. Most represent a single taxon tentatively referred to Inoceramus aff. glatziae (sensu Andert, 
1934, pl. 6, fig. 4). Some Mytiloides specimens and a single Didymotis are also recorded.

Bed 45a (limestone bed): entry level and flood occurrence of Cremnoceramus waltersdorfensis waltersdorfensis. The species is common up to the top of Bed 46, is still richly represented higher in Bed 47a, although not as common as below, and ranges up to Bed 52. This Cremnoceramus flood occurrence, spanning the base and middle of Bed 45a, is termed the waltersdorfensis Event. As first recognized by Bräutigam (1962), the replacement of the terminal Turonian Mytiloides-dominated assemblages by near-monospecific Cremnoceramus assemblages at this level is a striking and dramatic faunal change, readily identifiable both here and in correlative sections. The bed (mainly its top immediately beneath the thin detrital marl separating it from the overlying Bed 45b) contains the Didymotis II Event, characterized by a flood occurrence of strongly ornamented Didymotis cf. costatus (Frič), still accompanied by a nearly monospecific inoceramid assemblage of C. w. waltersdorfensis. The Didymotis morphotype in Bed 45a is larger and posteriorly more elongate than the Didymotis I morphotype in Bed 39. It is additionally characterized by finer, sharper, and more closely spaced commarginal rugae crossed by radial elements. We consider that this morphotype is best referred to $D$. costatus (see also discussion in Wiese, 1997; Seeling and Bengtson, 2003). Contrary to earlier statements (e.g., Wood et al., 1984; Kauffman et al., 1996), this event does not fall in limestone Bed 45b, which contains fewer fossils and may mark a reduced sedimentation rate. The ammonite Scaphites kieslingswaldensis Langenhan and Grundey makes its first appearance in Bed 45.

Bed 46: THE BASE OF THE CONIACIAN STAGE (marl bed), marked by a flood occurrence of small $C$. waltersdorfensis waltersdorfensis, with rare, small $C$. deformis erectus, the primary marker of the base of the Coniacian, noted in the basal part of the bed. The inoceramids are very well preserved, albeit somewhat distorted due to compaction, and commonly retain large portions of their shells and hinge plates. Based on the correlation to the Słupia Nadbrzeżna succession, Bed 46 corresponds to the interval from the LO of $C$. deformis erectus to the level of the erectus I Event. This means that Bed 46 should be regarded as a condensed bed. Consequently, the mass occurrence of C. w. waltersdorfensis in this bed, which was formerly interpreted as constituting the waltersdorfensis II Event (see Wood et al., 2004), reflects only a reduced sedimentation rate, rather than a distinct bioevent.

Bed 47a (limestone bed): the base of the bed is characterized by the flood occurrence of $C$. deformis erectus, constituting the erectus I Event. Within this event, $C$. deformis erectus is associated with its ancestral form, C. w. waltersdorfensis, in somewhat lesser abundance, and with very rare Didymotis.

Bed 49a (limestone bed): horizon with the next flood occurrence of C. deformis erectus (erectus II Event).

Bed 52b (marl bed): horizon with flood occurrence of $C$. waltersdorfensis hannovrensis (Heinz), interpreted as the hannovrensis Event (= waltersdorfensis hannovrensis Event of Wood et al., 1984). Starting with the hannovrensis Event, the inoceramid community in the Salzgitter-Salder section starts to diversify, although it remains generally dominated by C. waltersdorfensis hannovrensis up to Bed 73 .

Bed 53a (limestone bed): common C. w. hannovrensis are accompanied by larger forms of the deformis lineage (but still referrable to
C. deformis erectus), and numerous and variable representatives of the genus Tethyoceramus Sornay (non Heinz). This was designated the erectus III Event (corresponding to the erectus Event of Wood et al., 1984). This level marks a sudden increase in inoceramid taxonomic diversity (see Walaszczyk, 2000) and may record an immigration event.

Bed 67 (limestone bed): the LO of the ammonite Scalarites turoniense (Schlüter), followed by a new ammonite assemblage above, may be coeval to the base of the $F$. $(H$.) petrocoriensis Zone as defined in Westphalia (Kaplan and Kennedy, 1994).

Bed 73 (limestone bed): the uppermost $10-15 \mathrm{~cm}$ of the bed contains an acme of the species $C$. crassus inconstans, accompanied by rarer C. w. hannovrensis and very rare, huge Inoceramus annulatus Goldfuss.

Bed 75 (limestone bed): flood occurrence of Micraster (Isomicraster) sp. associated with inoceramids, the latter represented mostly by $C$. w. hannovrensis, C. crassus inconstans, and forms transitional between $C$. w. hannovrensis and C. crassus inconstans.

\section{Biostratigraphy}

\section{Macrofossils}

Inoceramids (Ireneusz Walaszczyk): In the Salzgitter-Salder section, inoceramid bivalves occur in abundance. In this report, we discuss those inoceramid occurrences from Bed 21 in the Grauweiße Wechselfolge Member to the top of the succession discussed - i.e., to the top of Bed 78 (Fig. 5). The inoceramid record of the boundary interval is well known and largely understood. The lower part of the interval, up to Bed 43, is dominated by M. scupini, M. herbichi, and Inoceramus lusatiae, all of which characterized the late Turonian $M$. scupini Zone. Mytiloides continues into Bed 44, where they are accompanied by poorly understood forms, referred previously by Wood et al. (2004) to Inoceramus aff. glatziae Andert. A better understanding of I. aff. glatziae may be crucial to properly interpret the phylogeny and evolution of the entire Cremnoceramus clade.

An abrupt inoceramid bivalve turnover occurs at the base of limestone Bed 45a, with the total disappearance of Mytiloides and a mass appearance of $C$. w. waltersdorfensis (Figs. 6D-G), the zonal index of the terminal Turonian C. w. waltersdorfensis Zone. This taxon is the oldest representative of the Cremnoceramus clade, the dominant component of the inoceramid fauna through most of the early Coniacian. It is noteworthy that the Cremnoceramus clade appears suddenly at this level, without any apparent ancestors in the underlying succession either at Salzgitter-Salder or in correlative successions elsewhere. Cremnoceramus waltersdorfensis shows very slow anagenetic change up to Bed 52, where a clear shift towards a more elongated morphotype is noted. Accordingly, two chronosubspecies of C. waltersdorfensis have been distinguished: the older, nominative one, and the younger hannovrensis. Bed 45a contains a monospecific accumulation of the older subspecies, C. w. waltersdorfensis, constituting the waltersdorfensis Event.

The acme occurrence of $C$. w. waltersdorfensis in Bed 46 was previously interpreted as monospecific and referred to the waltersdorfensis II Event. However, this must be reinterpreted, as Bed 46 also contains the first $C$. deformis erectus (see Voigt et al., 2021). The subspecies erectus is the oldest chronosubspecies of the C. deformis lineage (see Walaszczyk and Wood, 1998; Walaszczyk and Cobban, 2000), 
which branched off from the waltersdorfensis lineage relatively early in the history of the Cremnoceramus clade.

A careful comparison of the boundary record in Salzgitter-Salder and Słupia Nadbrzeżna shows that the flood occurrence of C. w. waltersdorfensis in Bed 46, associated with the first sporadic occurrence of $C$. deformis erectus, could be interpreted as a result of reduced accumulation rates in the Salzgitter-Salder succession. In Słupia Nadbrzeżna, the equivalent succession between the watersdorfensis and the erectus I events, in Bed 47a, is about $2 \mathrm{~m}$ thick, while it is $\mathrm{c} .70 \mathrm{~cm}$ in Salzgitter-Salder.

Cremnoceramus deformis erectus (Figs. 6A-C) and C. w. waltersdorfensis dominate the interval up to Bed 52, where C. w. hannoverensis, which ranges up to the top of the studied interval, first appears. In Bed $73, C$. w. hannoverensis gives way to the $C$. crassus lineage. This transition is interpreted as a cladogenetic event. Two chronosubspecies are recognized within the lineage, $C$. crassus inconstans and $C$. crassus crassus. Bed 73 yields a richly represented assemblage of C. c. inconstans with an entire range of transitional forms between it and C. w. hannoverensis.

A very intriguing event in the early Coniacian history of inoceramids is the appearance of a morphologically and taxonomically variable genus Tethyoceramus, richly recorded in Bed 53a and apparently ranging higher in a poorly recognized pattern. Most of the morphotypes are still in need of careful taxonomic interpretation, however, they definitely represent a group of well-defined species (see, Walaszczyk, 2000).

Didymotis bivalves (Ireneusz Walaszczyk): The thin-shelled bivalve genus Didymotis is a significant component of the molluscan faunas in the Turonian-Coniacian boundary succession (Fig. 5). Of particu- lar biostratigraphic importance are levels of relative abundant occurrence of these bivalves (these acme occurrence levels are referred to as Didymotis events).

The lowest, admittedly rare records of Didymotis from SalzgitterSalder are from Bed 17 (Čech and Uličný, 2021), extending up to Bed 29. The top part of this range equates with the Didymotis 0 Event identified at or near this level by Wiese and Kröger (1998). Higher up, Didymotis occurs in relative abundance starting in Bed 37. In Bed 39, it is associated in abundance with I. lusatiae, M. herbichi, and M. scupini, which constitutes the Didymotis I Event (Wood et al., 1984, 2004). The Didymotis I morphotype is characterized by broadly rounded, thick commarginal rugae, with relatively wide interspaces and little or no radial ornament. Higher up, Didymotis occurs in abundance in Bed 45a together with common C. w. waltersdorfensis. This occurrence of Didymotis, associated with the first occurrence of the genus Cremnoceramus, constitutes the Didymotis II Event. The Didymotis II morphotype is typically larger and posteriorly more elongate than the Didymotis I morphotype and is additionally characterized by finer, sharper, and more closely spaced commarginal rugae crossed by more or less strongly developed radial ribs. The Didymotis II morphotype is closely related to or conspecific with D. costatus. Above the Didymotis II Event, rare Didymotis occur up to Bed 47a. Of importance is a large-size, circular outline morphotype of Didymotis reported from the middle part of the C. deformis erectus Zone of Słupia Nadbrzeżna. Its projected level in Salzgitter-Salder is marked in Fig. 5. A still younger record, from the C. deformis deformis / C. crassus crassus inoceramid Zone, comes from the Březno section in Bohemia (see Čech and Švábenická, 1992).

Ammonites (Frank Wiese and William James Kennedy): Ammonites are generally rare in the Salzgitter-Salder section, except in some event

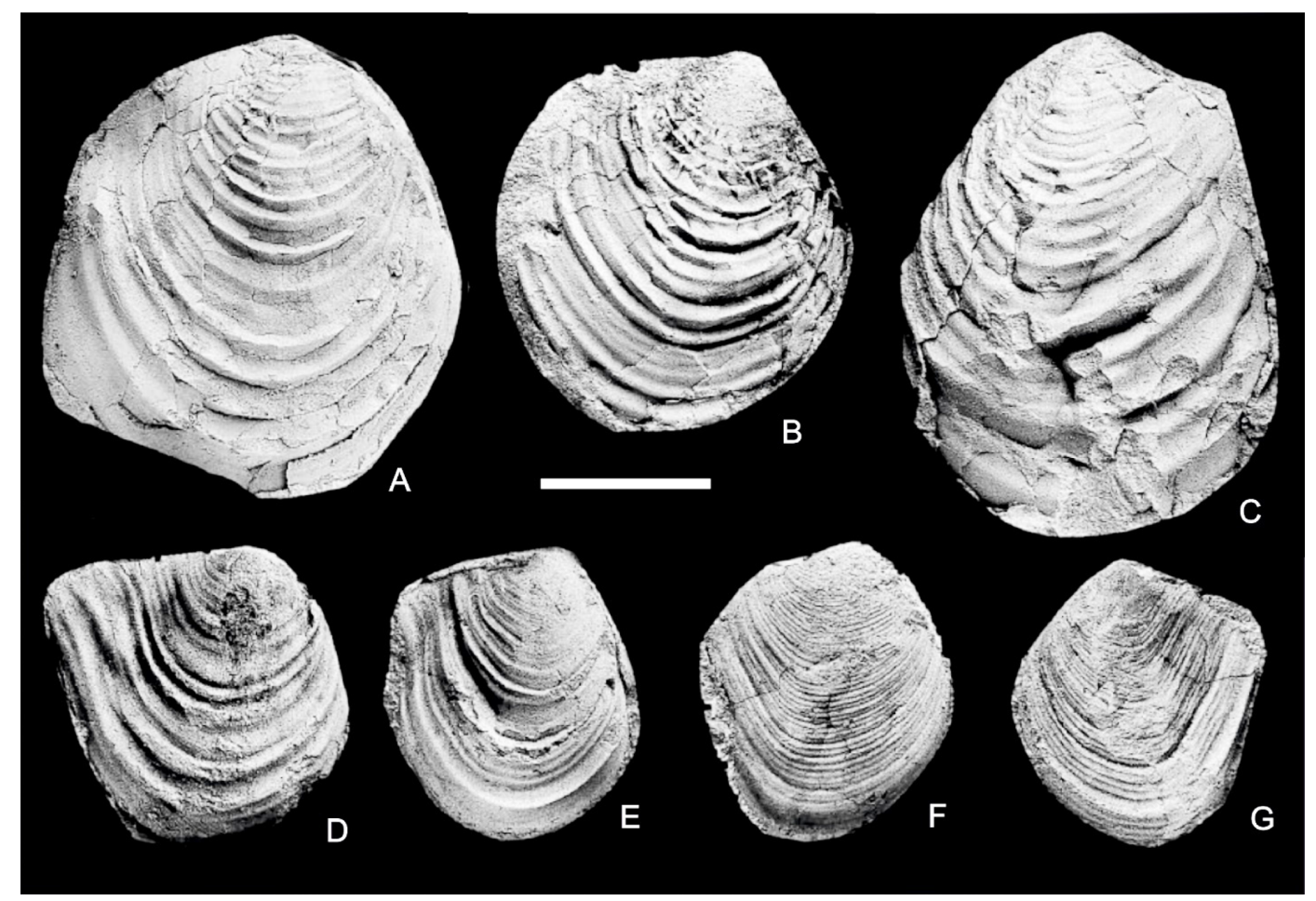

Figure 6. Key inoceramid Turonian-Coniacian boundary markers. (A-C) Cremnoceramus deformis erectus (Meek); Salzgitter-Salder, C. d. erectus Zone; bed 47. (D-G) Cremnoceramus waltersdorfensis waltersdorfensis (Andert), Stupia Nadbrzeżna, C. waltersdorfensis waltersdorfensis Zone. Scale bar is $2 \mathrm{~cm}$. 
beds (e.g., Hyphantoceras Event; Dahmer and Ernst, 1986; Wood and Ernst, 1998). For the Turonian-Coniacian boundary interval, finds from bed-by-bed collecting in the recent past are scarce, and the ammonite data constitute a literature synthesis of records and ranges (e.g., Wood et al., 1984; Ernst and Wood, 1995, 1998; Wiese 2000), supplemented by new finds, the latter mostly collected from scree and not of immediate significance to the boundary discussion (Fig. 5). Characteristic for the boundary interval is the complete absence of biostratigraphically significant Collignoniceratidae and the dominance of a scaphitid/baculitid fauna together with rare nostoceratids/diplomoceratids (Wiese in Walaszczyk et al., 2010). Compared to correlative strata in Westphalia with rare collignoniceratids and a higher species richness (Kaplan and Kennedy, 1994), the Salzgitter-Salder assemblage expresses a more distal or deeper water setting (compare Westermann, 1996).

Bed 29-Bed 45: In the scaphitid/baculitid ammonite assemblage of the terminal Turonian, Scaphites geinitzii (d'Orbigny) together with Scaphites diana (Wright), S. cf. diana (base of Bed 35: Ernst and Wood, 1995), Scaphites kieslingswaldensis Langenhan and Grundey (LO Bed 45) and Hyphantoceras ernsti Wiese (Bed 29) occur, the latter seen as a synonym of Hyphantoceras flexuosum (Schlüter) by Kennedy (2020, p. 130) and Kennedy and Kaplan (2019, p. 90). Scaphites kieslingswaldesis doylei (Wright) as reported by Wiese in Walaszczyk et al. (2010) is now interpreted to be synonymous with $S$. diana (Kennedy and Kaplan 2019, p. 103; Kennedy, 2020, p. 180). Ubiquitous albeit not abundant are poorly preserved baculitids, most of which are probably Sciponoceras bohemicum (Fritsch). However, Baculites enters the stratigraphic record in the upper Turonian Subprionocyclus neptuni Zone (Wright, 1979), and future finds may well reveal the occurrence of that genus. The HO of Lewesiceras mantelli (Wright and Wright) falls into an interval between Beds 29 and 39.

Bed 46-Bed 47a: The immediate Turonian-Coniacian boundary (FAD of C. deformis erectus in Bed 46) has produced no ammonites (compare Ernst and Wood, 1998).

Bed 47-Bed 75: The ammonite assemblage in the C. w. hannovrensis Zone contains S. kieslingswaldensis, Scalarites turoniense (Schlüter) (LO Bed 67) and Neocrioceras paderbornense (Schlüter) (LO Bed 75). There exists a single specimen of Placenticeras orbignyanum (Geinitz) (around Bed 63). Baculites brevicosta Schlüter has been collected loose below Beds 72 and 75. Hyphantoceras flexuosum was recorded from Bed 65 by Wood and Ernst (1998), but the specimen on which this record is based cannot be traced at present.

Ammonite zonations and the Turonian-Coniacian boundary at Salzgitter-Salder (Frank Wiese and William James Kennedy): The terminal Turonian P. germari Zone is well established in Europe (e.g., Kaplan and Kennedy, 1996; Diebold et al., 2018; Kennedy and Kaplan, 2019) and the US Western Interior (Kennedy et al. 2001). Further records from Brazil (Andrade 2005), Angola (Kennedy et al. 2001, p. 127), Madagascar (Diebold, 2012) and central India, for example, (Kennedy et al. 2003) demonstrate the widespread distribution of the species. Stratigraphically, it ranges into the boundary interval in the Czech Republic (Čech, 1989), while its main occurrence is largely restricted to the lower part of its range in northern Germany (Wiese, 2009; Kennedy and Kaplan, 2019). From Salzgitter-Salder, only a handful of fragments have been collected to date (Beds 6, 12, and 17, lower M. scupini Zone). The base of the germari Zone correlates with that of the scupini Zone, making this datum an important horizon for supraregional correlation (Wiese et al., 2020).

The base of the Coniacian has traditionally been placed at the LO of F. (H.) petrocoriensis (see, e.g., Kennedy, 1984a, b; Kennedy et al., 1995), which in northern Germany and Spain falls in the C. waltersdorfensis hannovrensis Zone (e.g. Kaplan and Kennedy, 1994, 1996; Küchler, 1998). However, Kennedy and Walaszczyk (2004) showed that its LO falls into the uppermost Turonian M. scupini Zone. The late Turonian occurrence of the genus is also recorded from the US Western Interior and Mexico [Forresteria (F.) peruana; Ifrim et al., 2019; Walaszczyk and Cobban, 2000]. In conclusion, there is so far no reliable intrabasinal ammonite datum which can be used to define the base of the Coniacian at the approximate level of the boundary as defined by inoceramid bivalves.

At Salzgitter-Salder, the HO of Scaphites diana is located in the upper Turonian M. scupini Zone, but it ranges into the lower Coniacian in Westphalia (Kennedy and Kaplan, 2019), where it has a slight overlap with Scaphites kieslingswaldensis. The LO of S. kieslingswaldensis in Bed 45 in Salzgitter-Salder approximates the boundary as defined by the FAD of $C$. deformis erectus, so the ammonite could potentially provide a general proxy for the boundary. The geographic distribution of kieslingswaldensis extends from Poland to Germany, the Czech Republic, Austria, Romania (?), Loir-et-Cher, Charente-Maritime, Aude and Var in France, northern Spain, Madagascar, and northern KwaZulu-Natal in South Africa (Kennedy and Klinger 2013).

The LO of Scalarites turoniense around Bed 67 (C. w. hannovrensis Zone), and the new ammonite assemblage above this level, may indicate the assemblage that characterizes the petrocoriensis Zone as defined in Westphalia (Kaplan and Kennedy, 1994). Considering the late Turonian FAD of $F$. $(H$.) petrocoriensis, the concept of a widely traceable $F$. petrocoriense Zone beginning at the base of the Coniacian is no longer valid (see above).

\section{Microfossils}

Foraminifera (Danuta Peryt and Zofia Dubicka): New foraminiferal studies of a 22-m-thick interval, spanning Beds 38 through 60 (Fig. 7), were conducted following the publication of Walaszczyk et al. (2010). This work had two main objectives: (i) the re-study of the planktonic foraminifera succession; and (ii) a study of the benthic foraminifera succession, which had not been addressed previously.

Planktonic foraminifera: Our new study confirmed the stratigraphic distribution of planktonic foraminifera in the Turonian-Coniacian boundary interval in the Salzgitter-Salder section presented earlier (Peryt in Walaszczyk et al., 2010). This study focused on biserial and planispiral forms - i.e., heterohelicids and globigerinelloidids, respectively, which were not discussed previously. The Turonian-Coniacian boundary interval in the Salzgitter-Salder section yields abundant planktonic foraminifera (Fig. 7). However, their preservation is poor due to recrystallization, which is moderate in marlstones and quite extensive in limestones. The taxonomic diversity of planktonic foraminifera is low to moderate, with slightly more than twenty species recorded. The group is dominated by cosmopolitan globigerine-shaped whiteinellids and double-keeled marginotruncanids. The species composition is typical of the Cretaceous Transitional or Temperate Province. Characteristic Tethyan umbilico-convex dicarinellids and single keeled marginotruncanids with acute peripheries are either very rare or absent. 
The most common taxa present are Marginotruncana [M. pseudolinneiana Pessagno, M. coronata (Bolli), M. marginata (Reuss), M. sinuosa Porthault, M. renzi (Gandolfi), M. paraconcavata Porthault] and Whiteinella $[W$. paradubia (Sigal), W. brittonensis (Loeblich and Tappan), W. baltica Douglas and Rankin, W. archaeocretacea Pessagno]. Dicarinella is not common and in the interval studied is represented by: D. imbricata (Mornod) and D. hagni (Scheibnerová). Dicarinella cf. primitiva (Dalbiez) (Fig. 8H) occurs sporadically in the uppermost Turonian, while no samples yielded D. concavata. Archaeoglobigerina bosquensis Pessagno (Fig. 8G) first appears in the topmost M. scupini Zone.

Heterohelicids are minor contributors to the Salzgitter-Salder foraminiferal assemblages and are mainly represented by the genus Planoheterohelix. The following taxa have been identified in the material studied: Planoheterohelix globulosa (Ehrenberg), P. paraglobulosa (Georgescu and Huber), P. reussi (Cushman), and P. praenuttali Haynes, Huber \& MacLeod (Figs. 8D-F).

Globigerinelloides is quite common in the finest fraction; G. ehrenbergi (Barr) is present throughout the interval studied. Single G. asper (Ehrenberg) finds come from Bed 42, in the upper M. scupini Zone.
Neither $D$. concavata, an index taxon of the eponymous zone embracing the base of the Coniacian Stage, nor $H$. huberi, recently acknowledged as a good proxy to the Turonian-Coniacian boundary, have been recorded in the Salzgitter-Salder section. However, both taxa (Figs. $8 \mathrm{~A}-\mathrm{C}, \mathrm{I}, \mathrm{J})$ are reported from El Rosario and Słupia Nadbrzeżna, the stratotype auxiliary sections, and their positions are projected precisely onto the stratotype succession. Archaeoglobigerina bosquensis has its lowest occurrence in the topmost part of the M. scupini Zone.

Benthic foraminifera: Benthic foraminifera from the SalzgitterSalder boundary succession are abundant but rather poorly preserved. The stratigraphically important lineages of the genera Stensioeina and Gavelinella are, however, recorded well enough to place the stratigraphically critical events precisely in the succession (Fig. 7). The events with the highest correlation potential for recognizing the base of the Coniacian Stage are the transitions within the lineages of Gavelinella vesca - G. praeinfrasantonica, Globototalites multiseptus - G. michelinianus, and Protostensioeina. All cases are interpreted as anagenetic species-level transformations, with narrow or very narrow transitional zones.

The most promising for the recognition of the base of the Conia-

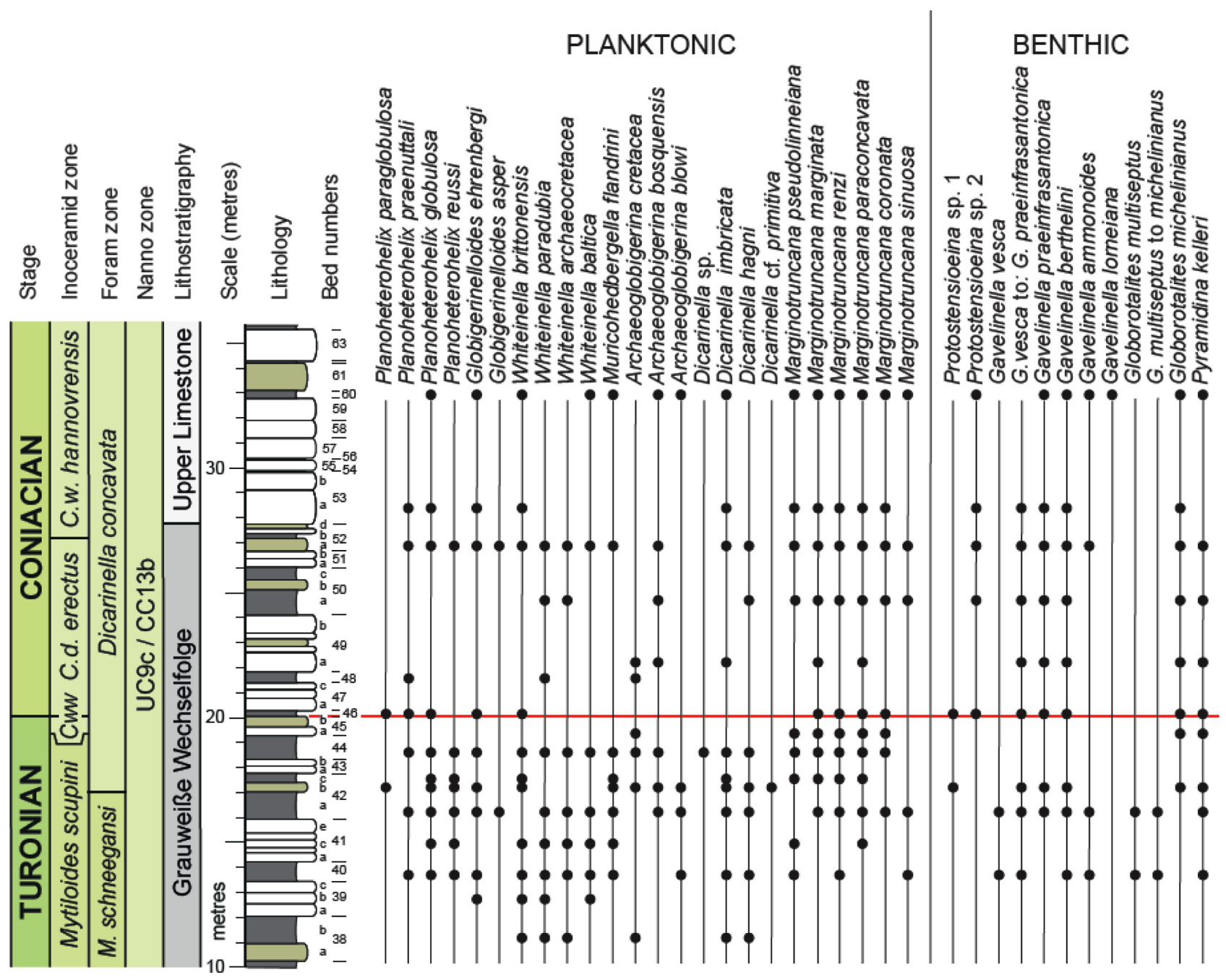

Figure 7. Stratigraphic distribution of planktonic and benthic foraminifera in the Salzgitter-Salder section. Cww-Cremnoceramus waltersdorfensis waltersdorfensis Zone; C.d. erectus - Cremnoceramus deformis erectus Zone; C.w. hannovrensis - Cremnoceramus waltersdorfensis hannovrensis Zone; M. schneegansi-Marginotruncana schneegansi Zone. 


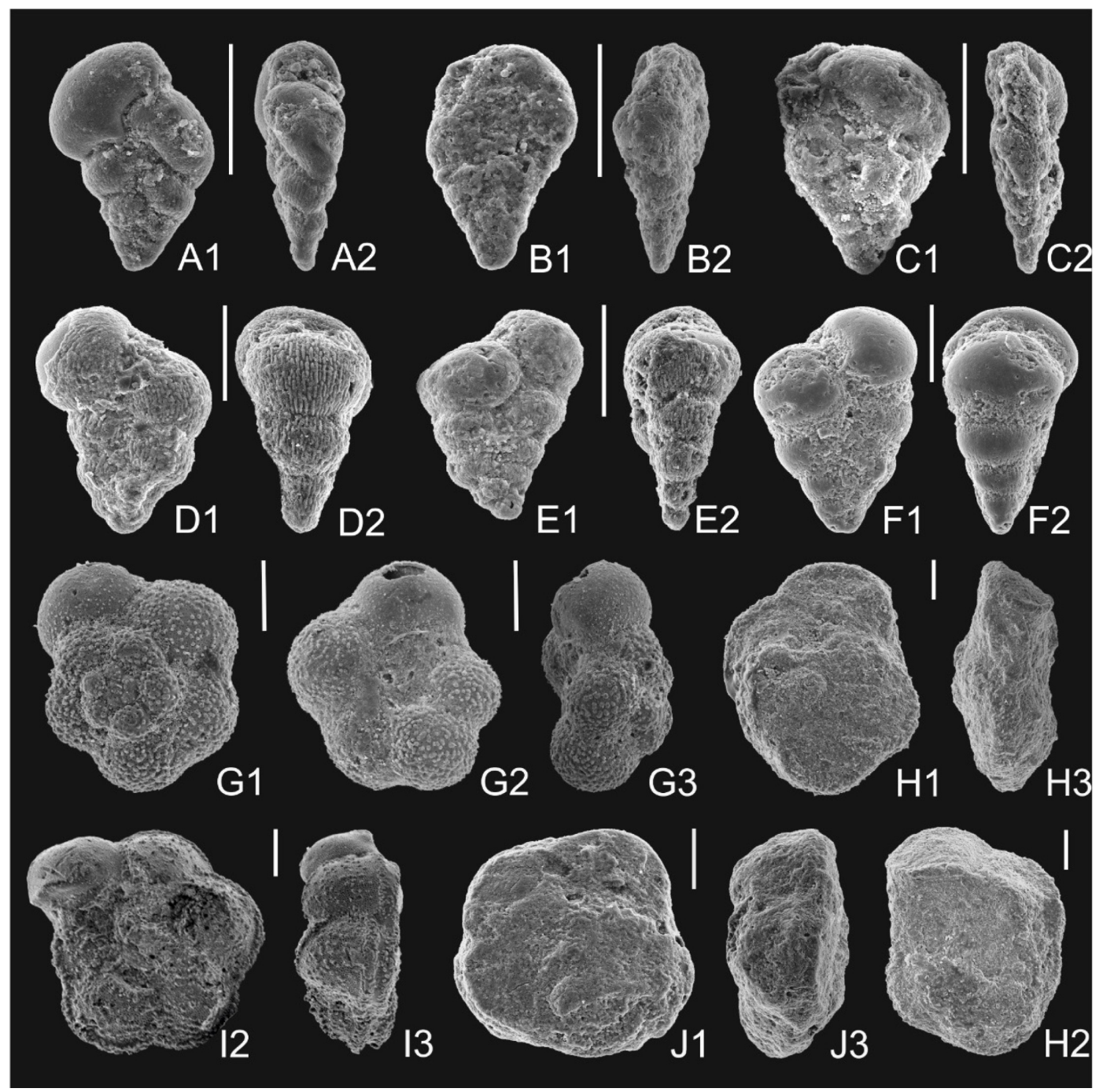

Figure 8. Stratigraphically important planktonic foraminifera from the Turonian-Coniacian boundary interval. $(A, B, C)$ Huberella huberi: $A-R$, Bed 32; B - R, Bed 24; C-R, Bed 13. (D, E, F) Planoheterohelix praenuttali: D-R, Bed 32; E-R, Bed 15; F-S-S, Bed 49. (G) Archaeoglobigerina bosquensis: SN, Sample 10. (H) Dicarinella cf. primitiva: S-S, Bed 50a. (I, J) Dicarinella concavata: I-SN, Sample 18; $J-R$, Bed 30. Scale bar $=100 \mu m$. SN-Stupia Nadbrzeżna; S-S -Salzgitter-Salder; R-El Rosario.

cian is the Protostensioeina lineage, with the transition from $P$. sp. 1 to $P$. sp. 2 (see Figs. 9A, B, D, G) (both left in open nomenclature so far) recorded in Bed 46, precisely at the base of the Coniacian as currently defined. The transition is morphologically expressed by the enlargement of umbilical flaps covering the umbilicus and the appearance of a convex umbilical area (Figs. 9D, G). This evolutionary event is known also from Poland, where it has been recorded close to the base of the $C$. deformis erectus Zone (Dubicka, unpublished data). Additionally, as far as the taxonomic description and illustrations in Koch (1977) can be followed, the Protostensioeina transitional event was recognized earlier at a similar level in NW Germany.

The two other lineages - i.e., Globorotalites multiseptus - G. michelinianus and Gavelinella vesca (Fig. 9E) - G. praeinfrasantonica (the latter within the G. vombensis lineage; see Dubicka and Peryt, 2014) - undergo the transition in the highest $M$. scupini Zone, with the completely developed descendant species, G. michelinianus and G. praeinfrasantonica, respectively, already present in the uppermost Turonian (Bed 42) (Fig. 7). The LO of G. praeinfrasantonica (Fig. 9F) has been described from roughly the same interval in Bohemia (Čech and Valečka, 1991; Hradecká, 1996), the Anglo-Paris Basin (Carter and Hart, 1977; Edwards, 1981), the Russian Cretaceous (Vasilenko, 1954; Beniamovski, 2008; Vishnevskaya et al., 2018), and Mangyshlak, Kazakhstan (Vasilenko, 1961). The LO of G praeinfrasantonica appears then to be an isochronous event, at least within the North European Province. The details of the stratigraphic appearance and distribution of G. michelinianus have not been widely discussed in the literature. Nevertheless, the event has been recorded in a comparable stratigraphic position in Poland (Dubicka, unpublished) and it seems to be a promising secondary marker for the Turonian-Coniacian boundary interval in the North European Biogeographic Province, and possibly beyond.

Finally, the evolutionary transition within the G. ammonoides (Fig. 9C) - G. lorneiana lineage may also be of value as a secondary marker for the basal Coniacian. This transition was recognized in the SalzgitterSalder section in the lower (but not lowermost) part of the lower Coniacian C. waltersdorfensis hannovrensis inoceramid Zone. Although the precise location of the FAD of G. lorneiana was not recognized, its LO is 


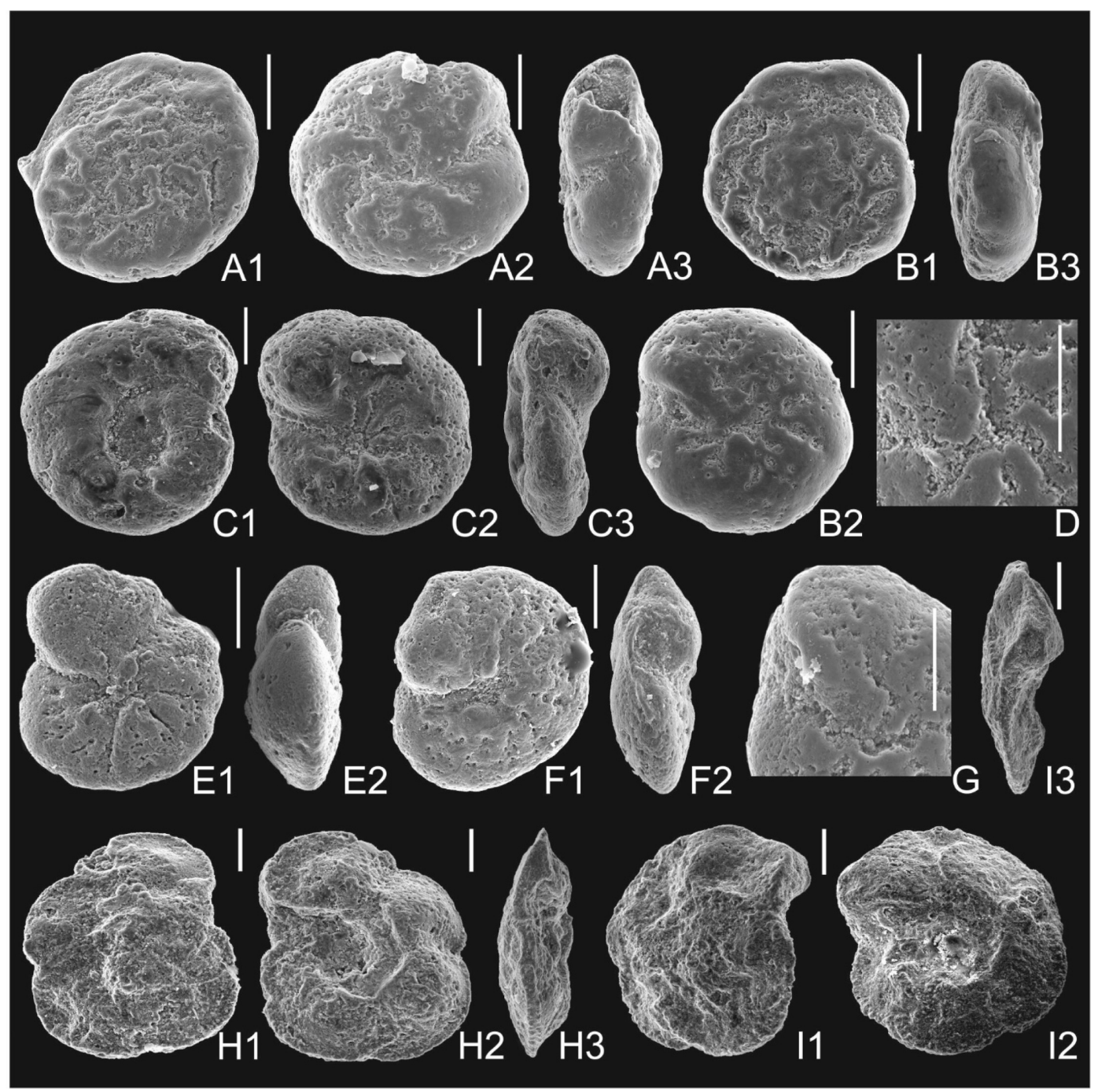

Figure 9. Stratigraphically important planktonic and benthic foraminifera from the Turonian-Coniacian boundary interval. (A) Protostensioeina sp. 1: S-S, Bed 42b. (B) Protostensioeina sp. 2: S-S, Bed 60. (C) Gavelinella ammonoides: S-S, Bed 40. (D) Protostensioeina sp. 2: S-S, Bed 60. (E) Gavelinella vesca: $S-S$, Bed 42. (F) Gavelinella praeinfrasantonica: $S-S$, Bed 60. (G) Protostensioeina sp. $1: S-S$, Bed 46. (H)

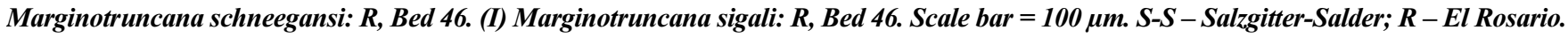

a good proxy for the European basal Coniacian. The event has been recorded in other European basins, at an apparently similar stratigraphic position (Edwards et al., 1981; Hradecká, 1996).

Nannofossils (Jackie Lees): The calcareous nannofossil assemblages and biostratigraphy of the Salzgitter-Salder section were first documented by Lees (2008) and also discussed by Lees (in Walaszczyk et al., 2010). A new study of Beds 32 through 66 by Püttmann (in Jarvis et al., 2021; see also Voigt et al., 2021) has confirmed the Lees (2008) biostratigraphy, and added relative abundance count data for the assemblages, extending the upper range of Helicolithus turonicus Varol and Girgis (a high-latitude indicator of the earliest Coniacian) by $\sim 6.5 \mathrm{~m}$, and postulating that the boundary lies within a cooling event, partially indicated by an abundance acme of Marthasterites furcatus (Deflandre in Deflandre and Fert) that occurs above the boundary.

According to Lees (2008, table 1), the assemblages are moderately rich taxonomically (varying from 9 to 56 species per sample), reasonably well-preserved (with individual samples containing very poor to moderately well-preserved specimens), and stratigraphically compa- rable to other coeval sections around the world (e.g., Lees, 2008, fig. 6). Püttmann (in Jarvis et al., 2021), who examined only marl samples, reported an equivalent $30-40$ species per sample. These findings contradict the conclusions of Sikora et al. (2004), who claimed that the nannofloras from the Salzgitter-Salder section were too poorly preserved and taxonomically depauperate to be of stratigraphic use. It was later determined by JL that their sample preparation technique had been at fault and had destroyed the nannofossil assemblages.

Lees (2008, table 2) recorded the calcareous nannofossils throughout the entire Salzgitter-Salder section, and at particularly high-resolution from Beds 35 to 53 (Lees, 2008, fig. 2). She determined that the base of the section (Bed T237; middle Turonian; see Wood and Ernst, 1998, fig. 5.5) lies in nannofossil subzone UC9a of the high-resolution, global biozonation scheme of Burnett et al. (1998), indicated by the presence of Lithastrinus septenarius Forchheimer and the absence of Zeugrhabdotus biperforatus (Gartner) at the base of the section. She found the top of the section (Bed 105; middle lower Coniacian) to lie in Subzone UC9c (the interval defined from the base of Broinsonia 
parca subsp. expansa Wise and Watkins to the base of Micula staurophora (Gardet), the latter defining the base of Zone UC10). Micula staurophora, a global marker species, is not present in the SalzgitterSalder section because the top of the section lies below this event. [N.B. In terms of the prior, low-resolution biozonation scheme of Sissingh (1977), as modified by Perch-Nielsen (1985), the entire section at Salzgitter-Salder lies within subzone CC13b, based on the presence of L. septenarius at the base of the section and the absence of M. staurophora at the top of the section.]

As explained by Lees (2008), the entire Turonian-Coniacian boundary interval is contained within Subzone UC9c. The marker for the base of the subzone, B. parca subsp. expansa, appears in the succession from Bed 7 (appearing as Marl T3 in Lees, 2008, fig. 2, table 1), well below the Turonian-Coniacian boundary interval.

No further significant nannofossil events were recognized in the interval below the boundary. Above the boundary, the nannofossil event closest to the boundary is the $\mathrm{HO}$ of $H$. turonicus, which was found $30 \mathrm{~cm}$ below the top of Bed 52 by Lees (2008, fig. 2, table 1); however, subsequent work (Püttmann in Jarvis et al., 2021 and Voigt et al., 2021) found the top of H. turonicus to lie $\sim 6.5 \mathrm{~m}$ higher, in Bed 62 . One other nannofossil datum to note above the boundary is the LO of Micula adumbrata Burnett in Bed 105.

According to Lees (2008, fig. 1), Marthasterites crassus (Deflandre) and M. furcatus have their LOs in Bed ME in the Salzgitter-Salder section, above the LO of $L$. septenarius. The genus Marthasterites has previously been reported as having a diachronous base (e.g., Lees, 2008, fig. 6), first occurring in either the lower or middle Turonian (Burnett et al., 1998, fig. 6.3); its base therefore has limited biostratigraphic utility and should only be employed as a local marker. However, Püttmann (in Jarvis et al., 2021, fig. 13) found M. furcatus to have two abundance acmes $\sim 4 \mathrm{~m}$ (Bed 50a) and $\sim \mathrm{m}$ (Bed 52) above the boundary, which may have some local palaeoceanographic significance, as these acmes occur above increased abundances of postulated cooler-water taxa (Biscutum, Kamptnerius, Zeugrhabdotus) that bracket the Turonian-Coniacian boundary.

Organic-walled dinoflagellate cysts (Ian Jarvis and Martin Pearce): The preservation of organic-walled dinoflagellate cysts (dinocysts) is generally poor, occasionally moderate at Salzgitter-Salder, with 8 technically barren samples (these are typically associated with beds exhibiting signs of weathering). Detailed range charts of palynomorph abundances have been presented by Jarvis et al. (2021). Except for two of the productive samples (Beds 32 and 64) a full count of 200 cysts was achieved, with an average absolute abundance of $\sim 1500$ palynomorphs per gramme; however, with no clear stratigraphic trend.

The marine assemblages are dominated by dinocysts of the open shelf Spiniferites - Palaeohystrichophora assemblage (see Pearce et al., 2003), with commonly occurring algal remains and rare acritarchs (Fig. 10). Dinocyst species richness in productive samples varied from 29 to 59 taxa with an average of 42 taxa, with no apparent trend. Terrestrial palynomorphs are poorly represented, typically $<5 \%$ of the total flora, with a species richness in productive samples of 1 to 6 taxa.

The long-term trend for the relative abundance of Palaeohystrichophora infusorioides Deflandre, generally the dominant species in the assemblage, falls upwards through the sample interval from Bed 34 to a minimum of $<10 \%$ in Beds 45 and 46 (Bed 47 yielded no palynomorphs). The species then rises to higher values of $30-50 \%$ from Bed 50a upwards (Fig. 10). Sepispinula ambigua (Deflandre) Masure has a broadly inverse relative abundance relationship with $P$. infusorioides and has an acme in Bed 49b. The Circulodinium - Heterosphaeridium / Spiniferites - Palaeohystrichophora (C-H / S-P) assemblage ratio and dinocyst Shannon diversity both display broad peaks that span the boundary interval and reach maxima in Bed 46 (Jarvis et al., 2021, fig. 7).

The uppermost Turonian $P$. infusorioides abundance minimum that occurs within the interval of Navigation CIE (Fig. 10), and the marked influx and acme of the taxon with other peridinioid cysts that is observed in the lower Coniacian (the P. infusorioides Event) can be correlated between Germany, the Czech Republic and England (Jarvis et al., 2021, fig. 12). A broad maximum in the peridinioid/gonyaulacoid $(\mathrm{P} / \mathrm{G})$ cyst ratio occurs immediately above the top of the i7 Carbon Isotope Event that spans Beds 55-58 at Salzgitter-Salder, in the lower C. $w$. hannovrensis Zone (Fig. 10). The P. infusorioides Event provides a useful regional stratigraphic marker in successions yielding Spiniferites Palaeohystrichophora assemblages; it represents a productivity pulse, attributed to watermass reorganisation accompanying early Coniacian eustatic sea-level rise (Jarvis et al., 2021).

The highest occurrence of Cyclonephelium membraniphorum Cookson and Eisenack is recorded at the base of the Coniacian in Bed 46. Elsewhere, this species is known to occur sporadically in the Coniacian, with a probable late Coniacian LAD (Pearce et al., 2020). However, the Salzgitter-Salder records correspond well to the level of the highest consistent occurrence (HCO) of the taxon, which has been widely employed as an uppermost Turonian marker (Jarvis et al., 2021).

\section{Carbon isotope stratigraphy (Silke Voigt)}

A new high-resolution carbon isotope curve across the TuronianConiacian boundary horizon at Salzgitter-Salder allows for a precise definition of the Navigation CIE relative to the biostratigraphic record - in particular, calcareous nannofossil and inoceramid index taxa (Voigt et al., 2021). The overall trend consists of a steady decrease of stable carbon isotope values to the base of Bed 46, which is followed by a subsequent rise of $\delta^{13} \mathrm{C}$ values (Fig. 11). In this framework, the inflection point in the general carbon isotope curve - that is, the relative minima of $\delta^{13} \mathrm{C}$ values - constitutes the Navigation carbon isotope excursion. Voigt et al. (2021) presented two options for the definition of the Navigation CIE together with a cyclostratigraphic interpretation. Option 1 is the $4.00 \mathrm{~m}$-thick interval from Beds 42 a to base Bed 46 (top of the Didymotis I Event to the LO C. deformis erectus). Within this interval, the Navigation CIE shows the most negative values (i.e., a negative excursion on the long-term curve) and represents a single $\delta^{13} \mathrm{C}$ minimum (dark orange interval in Fig. 11). The Navigation CIE corresponds to two and a half precessional cycles in Option 1.

Option 2 extends the base of the Navigation CIE further down to Bed 39b (light orange interval in Fig. 11). Although the small $\delta^{13} \mathrm{C}$ trough (Bed 39b to 40) is still part of the long-term decline, the inclusion of the Didymotis I Event into the Navigation CIE provides additional support for correlation and identification of the event in more condensed successions. In Option 2, the Navigation CIE has a duration of one 100 kyr-eccentricity cycle. The top of the Navigation CIE is identical in Option 1 and Option 2 and is consistent with the old single-point definition of the boundary excursion (Voigt and Hilbrecht, 


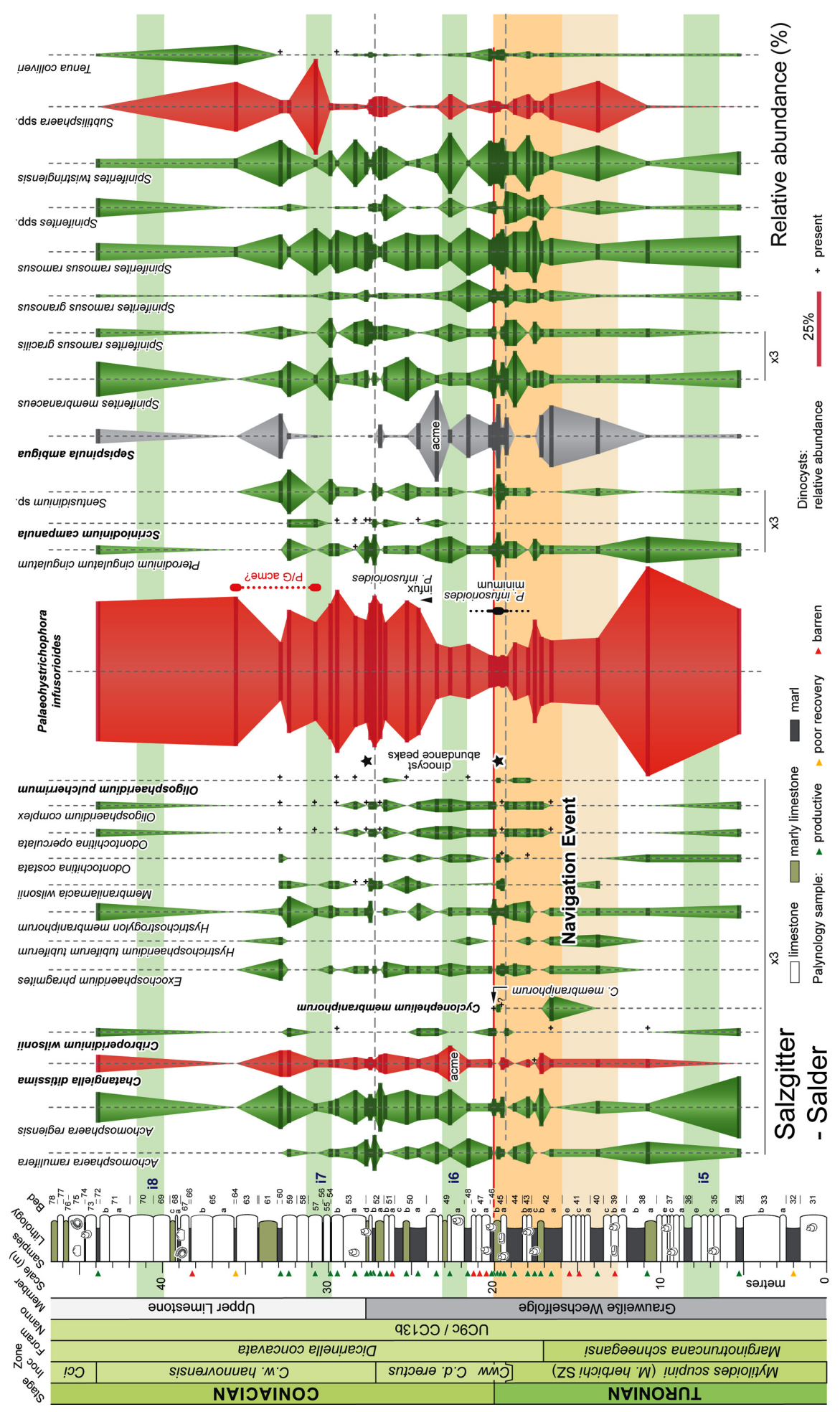

Figure 10. Dinocyst range chart showing the relative abundance of representative taxa from the Turonian-Coniacian boundary interval at Salzgitter-Salder. M. herbichi SZ-Mytiloides herbichi Subzone; Cww-Cremnoceramus waltersdorfensis waltersdorfensis Zone; C.d. erectus Cremnoceramus deformis erectus Zone; C.w. hannovrensis - Cremnoceramus waltersdorfensis hannovrensis Zone. Dark green bars and gradient shaded vertical columns are gonyaulacoid dinocysts, red ornaments represent peridinioid cysts, grey ornaments are cysts of uncertain taxonomic affinity. Relative abundances of accessory taxa are multiplied x3, as indicated, to better visualize stratigraphic trends. Horizontal coloured bars are carbon isotope events (see Fig. 11 and text for detail). Small black crosses indicate a species presence where this fell outside the quantitative count. Note the dominance of P. infusorioides and Spiniferites species and the inverse correlation of the former taxon with S. ambigua. The highest record of C. membraniphorum is from the base of Bed 46, the base of the Coniacian, consistent with the highest persistent occurrence of the species elsewhere in NW Europe (Pearce et al., 2020). Samples yielding an anomalously high absolute abundance of dinocysts (>3000 dpg), Beds $45 \mathrm{~b}$ and $52 \mathrm{~d}$, are highlighted by stars. The interval with a low relative abundance of P. infusorioides at the Turonian-Coniacian boundary and the level of influx in the lower Coniacian are highlighted. Modified from Jarvis et al. (2021). 


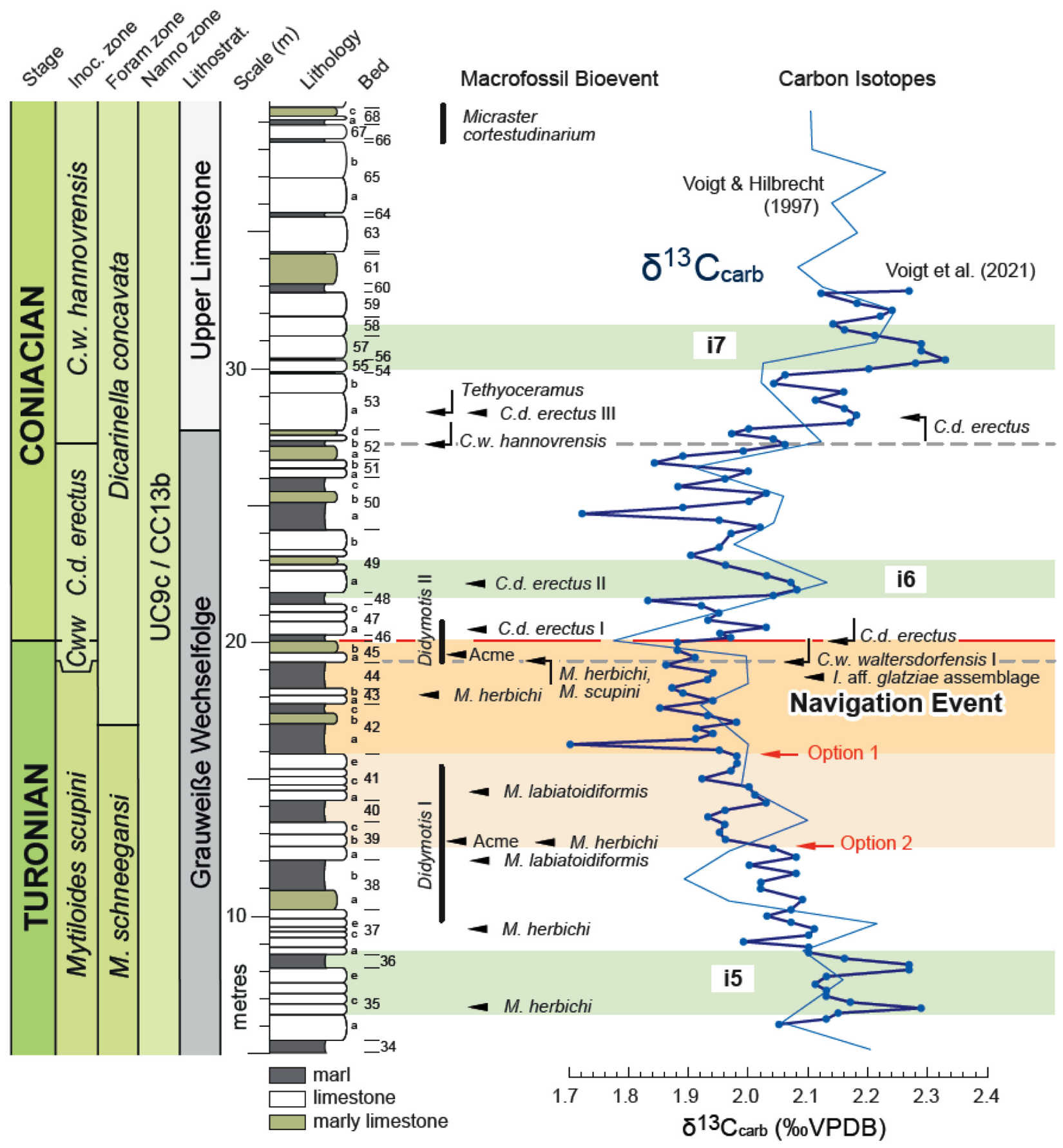

Figure 11. Carbon isotope stratigraphy across the Turonian-Coniacian boundary transition at Salzgitter-Salder. Bed numbers and the lithological log are redrawn from Wood et al. (1984). The red line at the base of Bed 46 marks the proposed T-C boundary horizon based on the LO/FAD of the inoceramid Cremnoceramus deformis erectus. The Navigation Event option 1 (dark orange bar) is represented by a 4.0 mthick horizon beneath the T-C boundary comprising the highest occurrences of Mytiloides scupini and M. herbichi, the second Didymotis Event and the lowest occurrence (LO) of Cremnoceramus waltersdorfensis waltersdorfensis (Cww). The base of the Navigation Event option 2 (light orange bar) is in Bed $39 b$ together with the Didymotis I Event. The top of the Navigation Event coincides with the LO/FAD of C. d. erectus. Boxed numbers are 'i5' to 'i7' are carbon isotope events (see text). Modified from Voigt et al. (2021).

1997; Walaszczyk et al., 2010). An overall trend towards elevated $\delta^{13} \mathrm{C}$ values commences above the Navigation CIE, so the break point coincides exactly with the Turonian-Coniacian boundary (Fig. 11).

A series of small-scale positive $\delta^{13} \mathrm{C}$ events, revealed within the high-resolution $\delta^{13} \mathrm{C}$ curve, have the potential to serve as markers for regional correlation (Jarvis et al., 2021; Voigt et al., 2021). Prominent positive shifts occur in Beds 35-36, in Bed 47 immediately above the Navigation CIE and the Turonian-Coniacian boundary, in Bed 49a together with the erectus II Event, in Bed 53a again together with the erectus III Event, and in Bed 57. The positive excursions in Beds 35-36, $49 \mathrm{a}$ and 55-58 are designated as the ' $\mathrm{i} 5$ ', ' 16 ' and ' $\mathrm{i} 7$ ' events, respectively according to the scheme of Jarvis et al. (2006) and Pearce et al. (2020). 


\section{Gamma ray (GR) spectrometry and magnetic suscepti- bility (MS) (Damian Lodowski)}

A preliminary GR spectrometry and MS study was conducted in the c. $60 \mathrm{~m}$ thick boundary interval (Beds 13-73) of the SalzgitterSalder succession. Field GR spectrometry (for eK, eU, and eTh) and MS measurements were taken using a Georadis RS230 portable gamma-ray spectrometer and a ZH Instruments SM-30 portable magnetic susceptibility meter, respectively. Due to the low gamma ray signal, only raw, uncalibrated data are presented (in cpm, counts per minute; Fig. 12).

Three overarching trends in the thorium (eTh) log are observed (Fig. 12): (I) a slightly increasing, although variable trend between
Beds 13 and 38b (not plotted); (II) a decreasing trend between Beds 39 and 57; and (III) an increasing trend through Beds 58-73 (already within the Upper Limestone Member). It is worth noting a pronounced correlation between the appearance of marly layers and local peaks in the eTh log, pointing to at least a partial lithological control on eTh, for instance due to carbonate dilution.

Uranium (eU) measurements (not plotted) generally decrease up to Bed 49b. A local peak and subsequent sharp decline in eU are observed in the interval spanning Beds 50 to 59. Authigenic U (see Wignall and Myers, 1988; Jones and Manning, 1994) was calculated and adopted as an index of bottom water anoxia, using the standard black shale $(\mathrm{Li}$, 2000) mean U/Th ratio as the norm. It generally possesses near-zero values (Fig. 12), with poorly pronounced trends through the section.

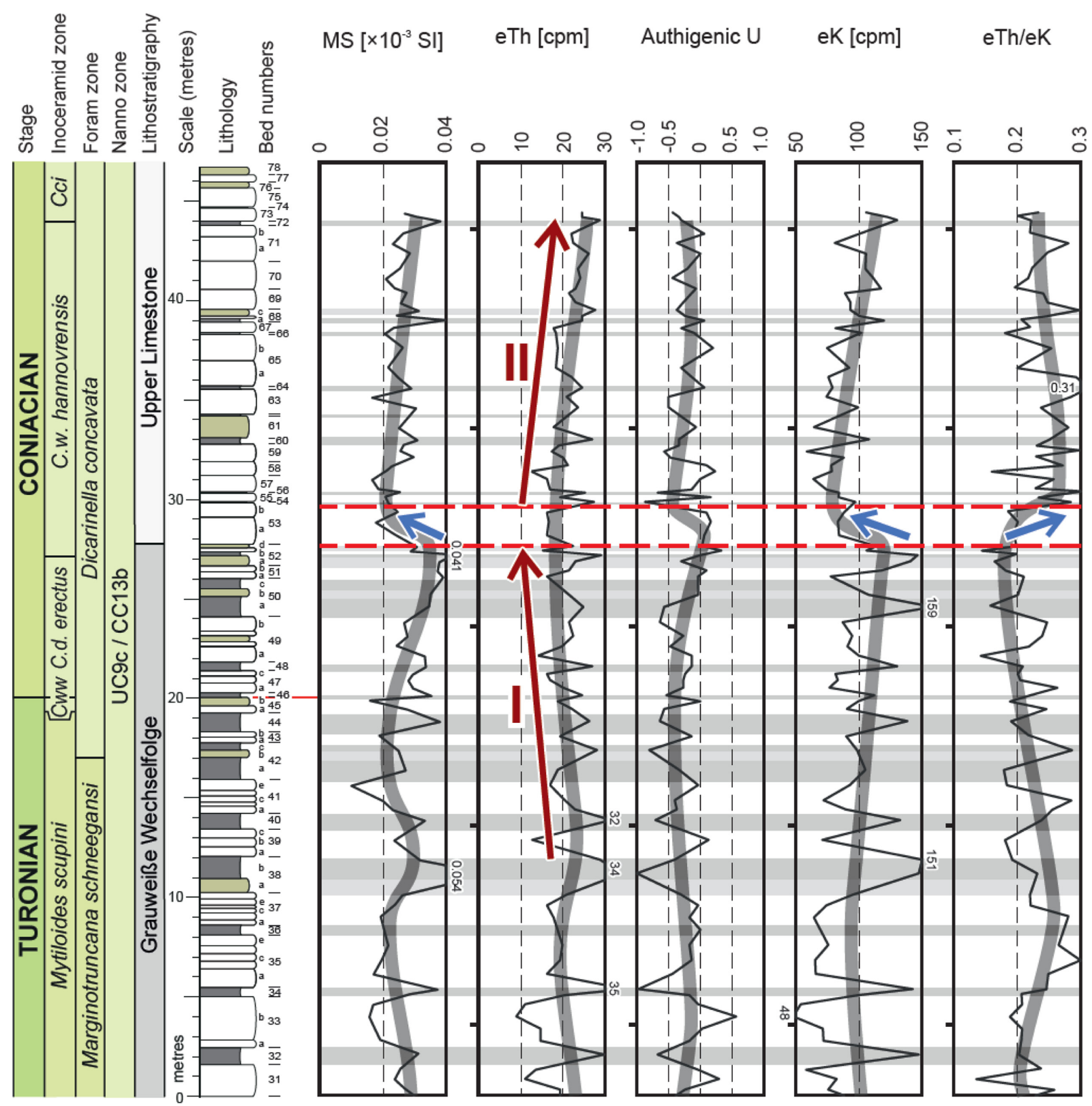

Figure 12. Magnetic susceptibility (MS) and field gamma ray spectrometry (eTh, authigenic $U$, eK, eTh/eK) logs of the Turonian-Coniacian boundary interval at Salzgitter-Salder. The dashed red lines bound an interval of presumably substantial environmental change. Blue arrows indicate trends observed within different proxies across the event. Red arrows indicate average trends within the eTh log. Thick grey curves reflects averaged trends. Gray and white stripes illustrate the alternation of marls and marly limestones respectively. 
The lower and middle parts of the section are characterized by an overall increasing trend in potassium content $(\mathrm{eK})$, although $\mathrm{eK}$ is quite variable (Fig. 12). Note, however, that a sharp drop does occur from Beds $52 \mathrm{~b}-57$, just above the major facies change within the succession (Grauweiße Wechselfolge to Upper Limestone Member transition).

MS values demonstrate a generally low abundance of magnetic minerals. A few local trends are present (Fig. 12); the most significant is a sudden decrease between Beds 52 and 53a. MS peaks are generally correlated with marl occurrence.

The recorded authigenic $U$ values reflect oxic bottom water conditions. Both eK and MS are strongly correlated with eTh (Pearson correlation coefficients (r) equal to 0.74 and 0.67 , respectively) implying that both signatures have primarily siliciclastic origins. It is worth noting that both MS and eTh logs reflects similar patterns: peaks generally occur within marls, and decreasing values are observed within the overlying limestones. This may be interpreted as a result of carbonate dilution, which would account for the lithologically controlled nature of MS and eTh. However, within the eTh log (see generalized eTh on Fig. 12) - unlike in the MS and eK logs - no major event is observed within the basal part of the Upper Limestone Member (Beds 52-55). Therefore, averaged GRS and MS logs (thick curves on Fig. 12) are thought to reflect their primary (pre-diagenetic) values. To confirm this, it would be useful to conduct similar investigations, including clay mineralogy analysis, in coeval and geologically equivalent successions, e.g. Słupia Nadbrzeżna.

Significant shifts in both the MS and GR profiles are observed from Beds 52 to 55 (basal part of the Upper Limestone Member); amongst these, the most noteworthy are sudden drops in the MS and eK logs (Fig. 12). In the context of eTh/eK as a palaeoclimate indicator (potassium is leached from clays during kaolinite formation under hot and humid climate conditions; Parkinson, 1996; Ruffel and Worden, 2000; Schnyder et al., 2006), the decline in the eTh/eK ratio across this interval is driven exclusively by K-depletion. As such, we interpret this event as a record of a sudden, although minor, climatic shift towards increased relative humidity.

Variations in eTh may result from numerous factors: for example, tectonic activity (uplift driving erosion), climatic variability (chemically driven weathering or aeolian transport), and eustasy (changes in the area of landmasses subjected to weathering). However, the timing of the eTh highs in relation to the local tectonic reconstructions of Voigt et al. (2006) and von Eynatten et al. (2007) suggests that tectonic influences were not a significant factor. On the other hand, thorium and potassium are characterized by significantly different densities, hence leading to different transportation potentials. Therefore, variations in the eTh/eK ratio may also be considered as evidence for a regressive event (e.g., Kozłowski and Sobień, 2012). In this model, the farther the coastline is from the area of study, the less thorium reaches it; the distance is controlled by relative sea level changes.

However, according to the eustatic models of both Hardenbol et al. (1998) and Haq (2014), the Turonian-Coniacian boundary coincided with a short-term regression (sea-level fall KTu5 event; ca. 90.5-89.5 Ma), which is not reflected by any clearly increasing trend within eTh across the interval. Moreover, when compared with coeval medium- and (especially) short-term sea-level curves for the Bohemian Basin (Uličný et al., 2014), no obvious correlation is observed. The above excludes a eustatic control on clastic influx, either indirectly by affecting the area of landmasses subjected to weathering, or by directly modulating the relative distance from the coastline. As a result, the most reasonable interpretation is that climatic influences were responsible for the observed variations in siliciclastic input proxies in the Salzgitter-Salder section.

The Salzgitter-Salder contains a very limited, albeit measurable, admixture of detrital grains, which were deposited under oxic bottom waters. Both the eTh and MS logs are associated with clastic admixture; changes in climate are thought to be responsible for their variations. An interval of sudden environmental disturbance is recognized between Beds 53 and 55 (base of the Upper Limestone Member); a slight increase in humidity is thought to be the most sensible explanation.

It should be noted that this work only covered the Turonian-Coniacian boundary interval; a paired GR-MS study spanning the entire succession exposed in Salzgitter-Salder (that is, middle Turonian-lower Coniacian) would be useful to tune and correlate the GR measurements with well-established climate events (e.g., the late Turonian cooling event; see Jenkyns et al., 1996; Deconinck et al., 2005; Jarvis et al., 2015). The nature of the relationship between the early Coniacian MS and $\mathrm{eTh} / \mathrm{eK} \operatorname{logs}$ is unclear and requires further study; rock-magnetic and clay mineralogy investigations would be useful to decipher the various factors driving their relative variation. It is suggested that similar investigations are conducted in correlative stratigraphic sections, in particular at Słupia Nadbrzeżna.

\section{Auxiliary Sections}

The stratigraphic record of Salzgitter-Salder, the primary stratotype section for the base of the Coniacian Stage, is supplemented by three auxiliary sections (Fig. 1): Słupia Nadbrzeżna (central Poland); the Střeleč railway cutting, adjacent to Střeleč Quarry (Bohemia, Czech Republic); and El Rosario, Sierra del Carmen National Park (Coahuila, Mexico). The Słupia Nadbrzeżna section offers the best and apparently most complete inoceramid record across the boundary and within the boundary interval. It has also yielded some ammonites, including a record of the critical ammonite taxon $F$. $(H$.) petrocoriensis. The Střeleč railway cutting provides essentially the same biostratigraphic record, but in a complementary depositional system strongly affected by terrigenous clastic input. The El Rosario section provides details of the boundary record from an area close to the southern entrance to the North American Western Interior Seaway. It confirms the synchroneity of the inoceramid record throughout the Euramerican Biogeographic Region and yields a rich ammonite faunal succession that is unmatched in any other Turonian-Coniacian boundary locality.

\section{Stupia Nadbrzeżna, central Poland (Ireneusz Walaszczyk)}

Słupia Nadbrzeżna (Figs 13, 14), in central Poland, is the auxiliary section with the richest and most complete inoceramid record across the Turonian-Coniacian boundary. In the previously proposed, composite stratotype section for the base of the Coniacian Stage (Walaszczyk and Wood, 2008; Walaszczyk et al., 2010), Słupia Nadbrzeżna was put forward as a companion section to Salzgitter-Salder. The former section has also yielded the oldest record of $F$. $(H$.) petrocoriensis (see Kennedy and Walaszczyk, 2004), the traditional ammonite marker of 
the base of the Coniacian. The main disadvantages of Stupia Nadbrzeżna are the very poor state of its exposure and the relatively short stratigraphic range of the exposed succession.

The Słupia Nadbrzeżna Turonian-Coniacian boundary section is part of the expanded Upper Cretaceous succession of the Middle Vistula River section, and is exposed along the Vistula River about $180 \mathrm{~km}$ south of Warsaw (Marcinowski and Radwański, 1983; Walaszczyk, 1992; Walaszczyk and Wood, 1998; Walaszczyk et al., 2010, text-fig. $2 b)$. The section is a natural river cliff in the village of Stupia Nadbrzeżna (geographic coordinates: $50.9504^{\circ} \mathrm{N}, 21.8071^{\circ} \mathrm{E}$ ), with a c. 10-metre-thick opoka succession [siliceous pelagic carbonates - see Jurkowska et al. (2019) for a recent review of opoka facies] exposed immediately to the north of a small valley entering the Vistula Valley in the centre of the village, along the western bank of the Vistula River.

\section{Lithostratigraphy and event stratigraphy}

No formal lithostratigraphy has been proposed for this part of the Middle Vistula Upper Cretaceous succession. Informally, it is level $a$ of Pożaryski (1938). The Turonian-Coniacian succession is marked by a series of bioevents equivalent to those recognized in the Salzgitter-Salder section (summarized in Wood et al., 2004). In the Stupia Nadbrzeżna section, the accessible Turonian-Coniacian boundary interval ranges from the $M$. herbichi Event to a short distance above the C. erectus I Event. The Didymotis II Event is within a C. w. waltersdorfensis Event (basal part of the eponymous zone).

\section{Faunal markers}

The M. herbichi Event, the oldest inoceramid event recognized in the succession, contains abundant and exceptionally well-preserved $M$. herbichi. The associated fauna includes I. lusatiae, uncommon M. scupini, and very rare Didymotis sp. In the $2.5 \mathrm{~m}$ thick interval between the M. herbichi Event and the terminal Turonian C. w. waltersdorfensis Event, there are several inoceramid occurrences, illustrating the inoceramid succession in the topmost part of the Turonian below the entry of Cremnoceramus.

Approximately $0.3 \mathrm{~m}$ above the $M$. herbichi Event, there is a level with rare M. herbichi, I. lusatiae, Inoceramus websteri (sensu Woods), and a thin-shelled form of uncertain affinity, referred to provisionally as Inoceramus aff. glatziae (sensu Andert). This is the highest level in the section that contains relatively common Mytiloides. Higher in the section, slightly over $1 \mathrm{~m}$ above the herbichi Event, there is a ca. $15 \mathrm{~cm}$ thick interval containing abundant large I. lusatiae. Single I. lusatiae specimens were also found slightly above and below their main concentration level. This interval has also yielded $I$. aff. glatziae sensu Andert and I. websteri sensu Woods. Above the I. lusatiae concentration (I. lusatiae Event), there is a level with fragmentary specimens of I. lusatiae and a possible Mytiloides. Inoceramids also occur sporadically a little above the previous level.

Above the Mytiloides interval, C. w. waltersdorfensis occurs in flood abundance in a massive, prominent unit of pure opoka, constituting the C. w. waltersdorfensis Event. The LO of $C$. deformis erectus (Meek) is marked by isolated occurrences of the taxon within a unit of cherty opoka ca. $0.75 \mathrm{~m}$ above the base of the $C$. w. waltersdorfensis Event. The acme of $C$. deformis erectus in this section occurs within a unit of pure opoka, some $2.2 \mathrm{~m}$ above the LO of the taxon, and defines the $C$. deformis erectus Event. The $C$. w. hannoverensis Event, with a flood acme of $C$. w. hannovrensis, occurs approximately $4 \mathrm{~m}$ above the $C$. $d$. erectus Event.

Representatives of the genus Didymotis, which characterize the topmost Turonian and basal Coniacian of at least the entire Euramerican Biogeographic Region, occur in the succession below and within beds with abundant C. w. waltersdorfensis. Didymotis shows both strong and weak to very weak radial ribbing across the entire interval, and there is no clear distinction between the Didymotis I and II (costatus) morphotypes as recognized in the Salzgitter-Salder section. Didymotis forms similar to D. costatus occur throughout the $C$. w. waltersdorfensis Event bed in association with the monospecific occurrence of $C$. $w$. waltersdorfensis. An as yet undescribed lower Coniacian giant form of Didymotis occurs in the topmost part of the C. deformis erectus Zone, where it appears to be limited to a single bed. Single specimens occur throughout the entire available succession.

\section{Planktonic foraminifera}

Records of planktonic foraminifera from the Słupia Nadbrzeżna section were discussed previously by Walaszczyk and Peryt (1998) and Walaszczyk et al. (2010), and the species ranges are shown in Fig. 13 (reproduced after Peryt in Walaszczyk et al., 2010). The heterohelicid species $H$. huberi has not been found, but the section has yielded Dicarinella concavata, the traditional foraminifera marker of the Turonian-Coniacian boundary (Robaszynski et al., 1990; Premoli Silva and Sliter, 1995; Robaszynski and Caron, 1995; Ogg et al., 2004), although this species is now known to range from the high upper Turonian to the top Santonian (e.g., Georgescu, 2017). The LO of M. sinuosa is recorded in the C. w. waltersdorfensis Zone.

\section{Organic-walled dinoflagellate cysts}

Dinocysts from the Słupia Nadbrzeżna section were recently studied by Olde et al. (2016, with a summary chart reproduced as Fig. 14 herein). They are well preserved, but of low abundance and low species diversity, with 5-11 species present per sample. Approximately $90 \%$ of assemblages throughout the succession is composed of four species: Circulodinium distinctum subsp. distinctum (Deflandre and Cookson) Jansonius, Oligosphaeridium complex Davey and Williams, Spiniferites ramosus subsp. ramosus (Ehrenberg) Mantell and Surculophaeridium longifurcatum (Firtion) Davey et al. (Olde et al., 2016).

The main Turonian-Coniacian boundary dinocysts recognized in the Bohemian Cretaceous Basin and elsewhere (Olde et al., 2015a, b; Pearce et al., 2020) have not been recorded in Słupia Nadbrzeżna. For example, the lowest occurrences of Surculosphaeridium belowii Yun and Cribroperidium, and the lowest common occurrence of Oligosphaeridium pulcherrimum (Deflandre and Cookson) Davey and Williams, are unrepresented due to an absence of the index taxa. Additionally, the highest consistent occurrence of Cyclonephelium membraniphorum Cookson and Eisenack and the highest occurrence of Kiokansium unituberculatum (Tasch) Stover and Evitt (a lower Coniacian marker; Olde et al., 2015a) are not observed in Słupia Nadbrzeżna.

Biostratigraphically significant dinocyst markers are: (1) the $\mathrm{HO}$ of Senoniasphaera turonica (Prössl) Pearce et al. (in the lowest $C$. deformis 


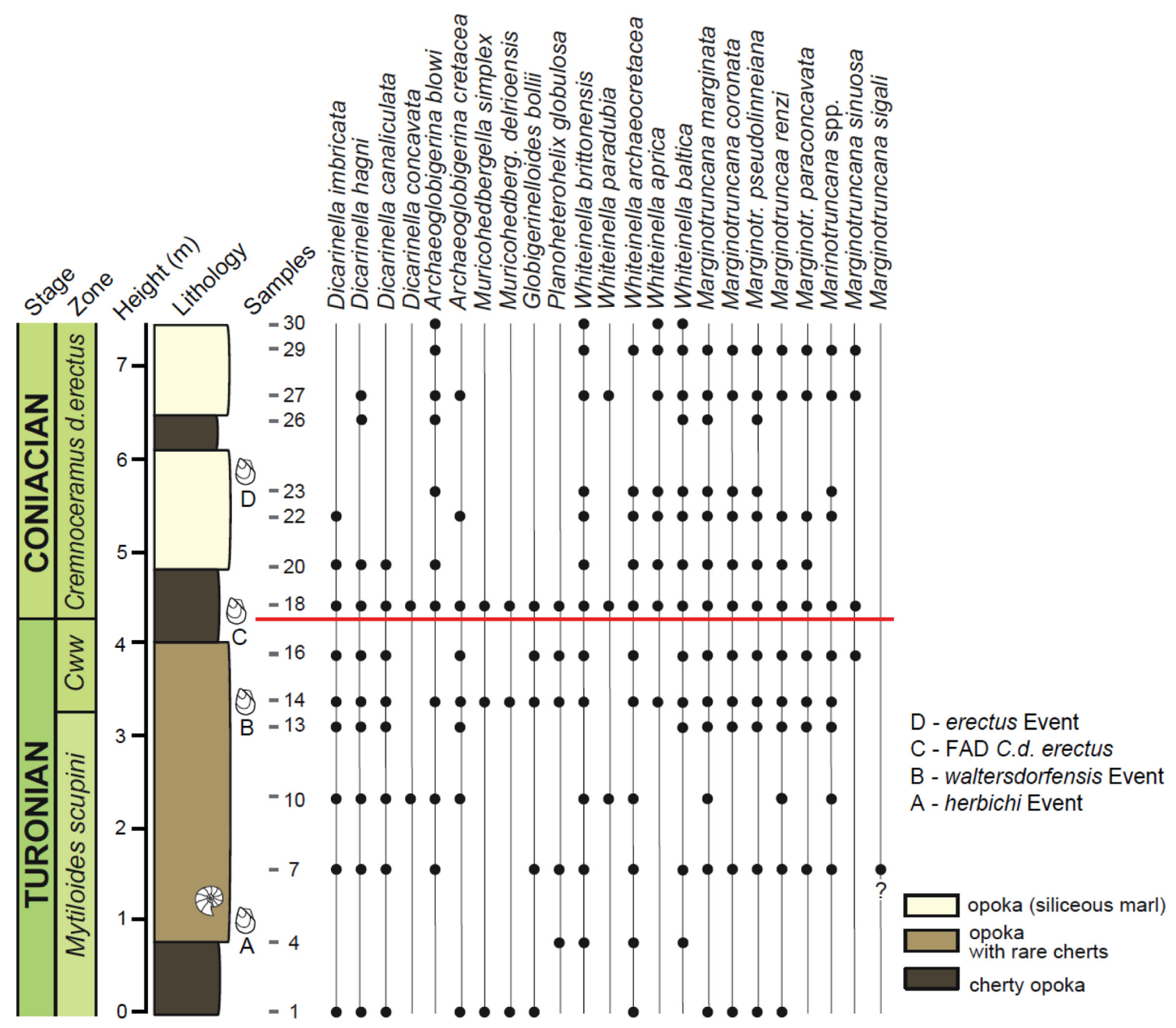

Figure 13. Stratigraphical distribution of planktonic foraminifera in the Turonian-Coniacian boundary interval in the Stupia Nadbrzeżna section. Adapted from Walaszczyk et al. (2010). Cww-Cremnoceramus waltersdorfensis waltersdorfensis Zone; Marginotr. - Marginotruncana.

erectus Zone); and (2) a dinoflagellate cyst abundance maximum in the uppermost Turonian C. w. waltersdorfensis Zone, also seen at Salzgitter-Salder (Fig. 10). The HO of S. turonica is not the LAD of the species, which ranges into the Santonian (Prince et al., 2008, as Senoniasphaera rotundata subsp. alveolata Pearce et al.), but corresponds to a level of highest persistent occurrence in the lower Coniacian (Pearce et al., 2003, 2020). The HO of S. turonica at Słupia Nadbrzeżna complements the record of a single specimen of Senoniasphaera sp. from the penultimate Turonian Bed 45a at Salzgitter-Salder (Jarvis et al., 2021).

The dinoflagellate cysts at Słupia Nadbrzeżna are suggestive of a shoal setting within an extensive shallow epicontinental sea, effectively restricted from siliciclastic source areas. The $S$. longifurcatum acme in the C. w. waltersdorfensis Event lies towards the top of the Navigation Event, and may indicate a short-term sea-level rise at this level.

\section{Střeleč railway cutting section, Czech Republic (David Uličný and Stanislav Čech)}

The expanded succession of the north-central Bohemian Cretaceous Basin contains a detailed record of the Turonian-Coniacian boundary interval, with an easily accessible exposure of the stage boundary in the Střeleč railway cutting (Fig. 15) next to Střeleč Quarry near Hrdoňovice in Bohemia, Czech Republic (geographic coordinates: $50.4967^{\circ} \mathrm{N}$, $15.2551^{\circ} \mathrm{E}$ ). The macrofaunal record shows the same succession of inoceramid and other molluscan marker taxa as the hemipelagics of the Salzgitter-Salder and Słupia Nadbrzeżna sections, but in a depositional system strongly affected by terrigenous clastic input. The principal features of the $\delta^{13} \mathrm{C}$ records, including interpreted carbon-isotope events, are consistent between Salzgitter-Salder and the Bch-1 reference section in Bohemia (Uličný et al., 2014; Jarvis et al., 2015; Čech and Uličný, 2021).

The Střeleč auxiliary section is located in the north-central part of the Bohemian Cretaceous Basin which in the latest Turonian through Coniacian was supplied with abundant clastic material. As a result, sand-dominated, Gilbert-type deltas with steep fronts formed at the faulted basin edge and prograded southwards, into water depth ranging from 60 to over $100 \mathrm{~m}$. The deposition of the bottomset/prodelta facies was dominated by fine-grained turbidites, strongly reworked by bioturbation and marine currents (Uličný, 2001).

Čech and Uličný (2021) showed that the Turonian-Coniacian boundary can be reliably traced between nearshore sandstones, cropping out 


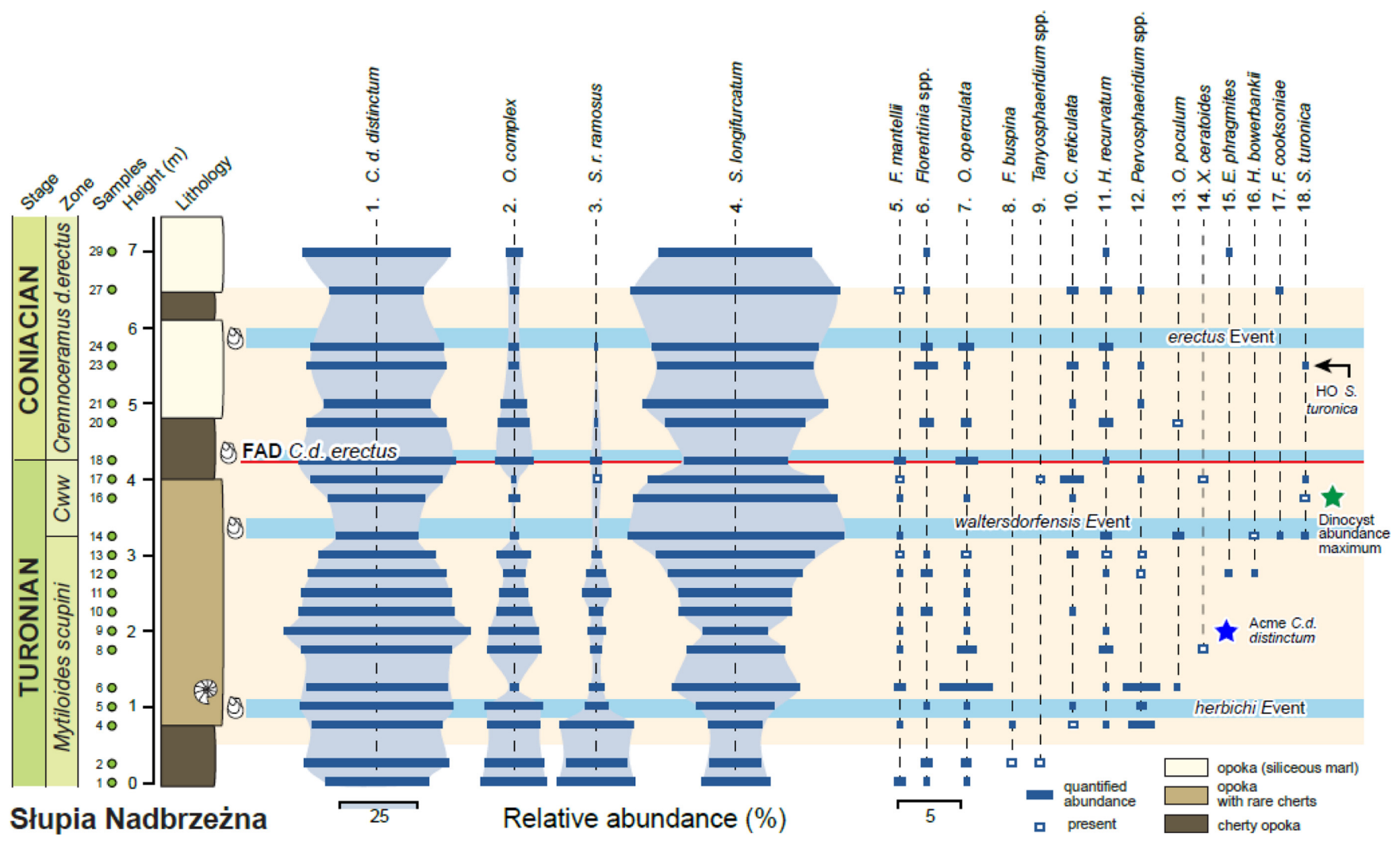

Figure 14. Range chart of dinoflagellate cyst species in the Stupia Nadbrzeżna section. Dinocyst abundances are given as the relative abundance of each species in the sample. Note the different abundance scales used for the four dominant taxa (blue shaded profiles; left) and other species (right). Potentially significant dinoflagellate cyst biostratigraphic datum levels are indicated. After Olde et al. (2016).

in the UNESCO Geopark Český ráj - Bohemian Paradise, to offshore and hemipelagic facies. In terms of regional stratigraphy, the TuronianConiacian boundary lies within the Teplice Formation sensu Čech et al. (1980), including the Hrubá Skála Sandstone Member as its newly defined subdivision (Čech et al., 2013). New data and previous work on the Střeleč section and the adjacent V-800m core were summarized in detail by Čech and Uličný (2021) and are illustrated in Fig. 15 here.

\section{Lithofacies}

The lower half of the exposure shows two intervals of dark grey, relatively silt-poor mudstones (from $0-1 \mathrm{~m}$ and 3.5-4.5 m height, Fig. 15), embedded within overall silt-rich mudstones to siltstones; the succession becomes sandier upward. The upper half is dominated by bioturbated, sand-rich siltstone to muddy, very fine-grained sandstone with abundant laminae of very fine-grained sandstone. The latter become more abundant upward and pass into several $\mathrm{cm}$ thick beds of clean, fine-grained calcareous sandstone. The beds are typically sharp-based, show a flat lenticular shape in cross-section, with a small lateral extent of up to 2-3 m. Parallel lamination and ripple cross-lamination are the most typical sedimentary structures, although commonly overprinted by bioturbation. Pot casts, described by Uličný (2001), are lenticular to pillow-shaped bodies of fine-grained sandstone, circular to oval in plan view, showing signs of erosion at basal contacts. They pass laterally into thin, flat-based, ripple-laminated, sandstone beds, and may contain accumulated shell debris or complete bivalve specimens.

\section{Faunal Markers}

In the V-800 core (Střeleč), the interval corresponding to the railway cutting begins at c. $64 \mathrm{~m}$ depth, above finds of $M$. herbichi and $M$. scupini at $65.2 \mathrm{~m}$ (Fig. 15). Lithological, gamma-ray, and carbon isotope correlation between outcrop and core suggests that this interval still belongs to the $M$. herbichi Zone: $2 \mathrm{~m}$ above the base of the railway cutting exposure (Fig. 15), the clear highest occurrence of M. herbichi is followed by the LO (and acme) of C. w. waltersdorfensis at $2.3 \mathrm{~m}$, accompanied by Didymotis costatus. Specimens of Didymotis occur between $68.3-55.3 \mathrm{~m}$ in the V-800 core. At $68.3 \mathrm{~m}$ only the morphotype with concentric rugae is represented, but above $65.1 \mathrm{~m}$ specimens with both concentric and radial rugae (D. costatus) are present. A comparison of various levels at which $D$. costatus appears in a wellconstrained, narrow interval across two parallel sections shows that it is difficult to make a distinction between separate levels corresponding to the Didymotis I and II events sensu Walaszczyk and Wood (1998).

In outcrop, the $\mathrm{LO} / \mathrm{FAD}$ of $C$. deformis erectus, marking the base of the Coniacian, is at $4.5 \mathrm{~m}$ height in the section shown in Fig. 15, i.e. $3.5 \mathrm{~m}$ below the base of the first heterolithic bottomset bed, and corresponding to a V-800 core depth of $59.5 \mathrm{~m}$. At $58 \mathrm{~m}$ core depth, a specimen of $C$. deformis erectus was found. C. w. waltersdorfensis and Didymotis costatus co-occur between $55-57 \mathrm{~m}$ core depth. Further occurrences of $C$. deformis erectus together with $C$. w. waltersdorfensis are found within the heterolithic bottomset facies, up to the top of the exposure at $15 \mathrm{~m}$ in Fig. 15. 

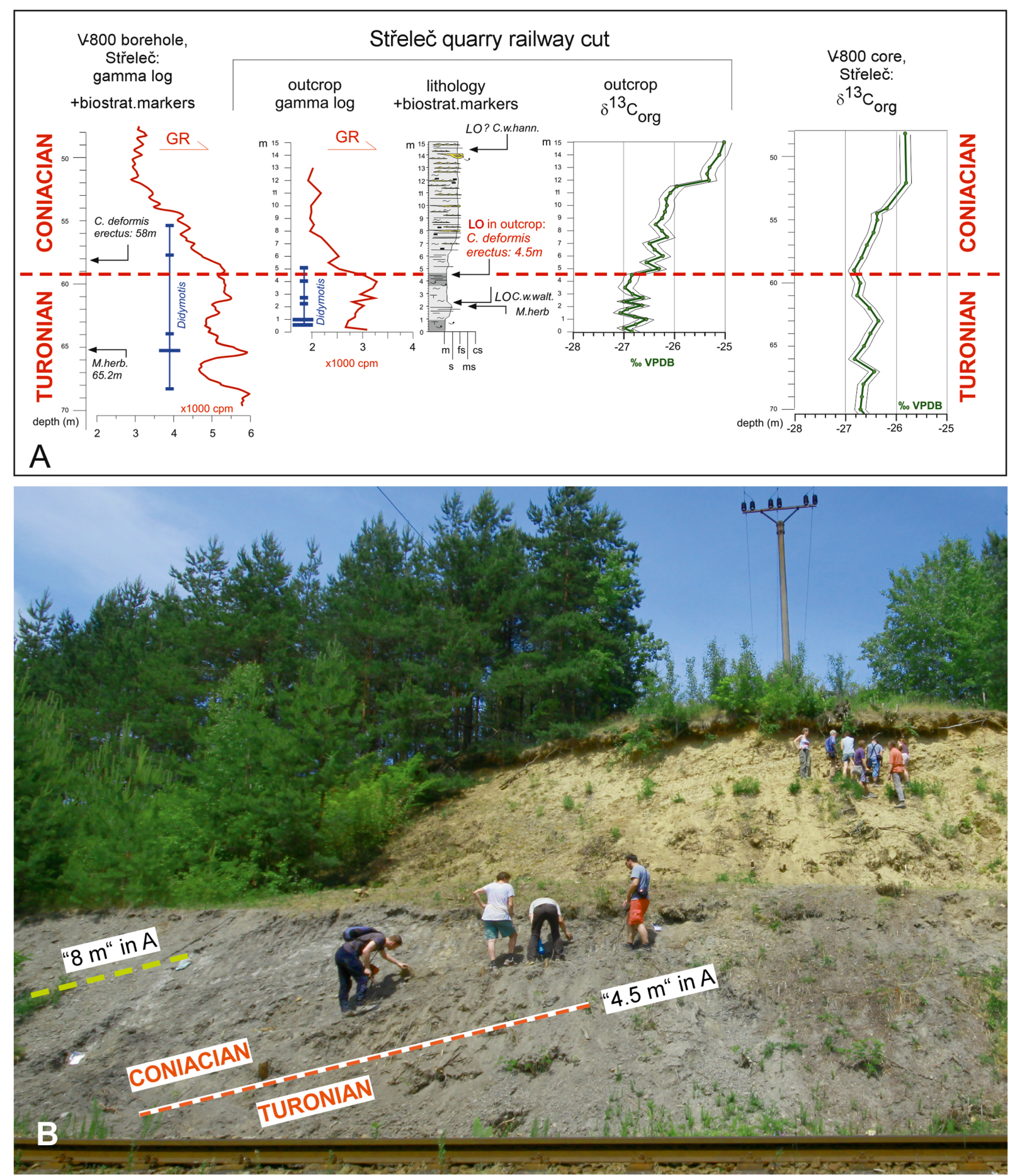

Figure 15. The Střeleč Turonian-Coniacian boundary succession in Bohemia, Czech Republic. (A) Lithological and gamma-ray logs, biostratigraphic, and $\delta^{13} C_{\text {org }}$ data from the Střeleč quarry railway cut, correlated to the relevant interval in the V-800 core, Střeleč quarry. In the $\delta^{13} C_{\text {org }}$ curves, the Navigation carbon-isotope event (CIE) is interpreted to correspond to a c. $10 \mathrm{~m}$ thick interval of lowered values, with the most negative values between the LO of Cremnoceramus waltersdorfensis waltersdorfensis and the LO of Cremnoceramus deformis erectus. M. herb. - Mytiloides herbichi. (B) Field photograph of the Turonian-Coniacian boundary exposure identified in outcrop. Modified from Čech and Uličny (2021). Photo in (B) by Jan Had Mertlik.

\section{Carbon isotope stratigraphy}

Organic carbon isotope data $\left(\delta^{13} \mathrm{C}_{\mathrm{org}}\right)$ from the railway cutting (Fig. 15) show an interval of the most negative values, c. $-27 \%$, near the base of the section, followed by a gradual increase in $\delta^{13} \mathrm{C}_{\text {org }}$ from around $5 \mathrm{~m}$ height. The most negative values in both outcrop and core span the first occurrences of both C. w. waltersdorfensis and C. d. erectus and are interpreted to represent an expanded record of the Navigation CIE. The $\delta^{13} \mathrm{C}_{\text {org }}$ values from outcrop and core are nearly identical within an analytical error of $\pm 0.15 \%$, except some departures in the outcrop 
section, where more closely spaced sampling in outcrop provided a higher-resolution curve than in the V-800 core.

\section{The El Rosario section, northwestern Coahuila, Mexico (Christina Ifrim)}

The El Rosario section (Fig. 16) illustrates a complete record across the Turonian-Coniacian boundary interval and has a comparable sedi- mentation rate to Salzgitter-Salder, the proposed boundary stratotype. Additionally, however, the Rosario section has an abundant ammonite record that can be correlated directly with the inoceramid succession and the stable carbon isotope curve. Moreover, it possesses a more continuous record of Didymotis bivalves, a group critical for the interpretation of the Turonian-Coniacian boundary succession in the Euramerican Biogeographic Region. The section ensures, then, a long-distance correlation of the northeastern Mexican Cretaceous to the European

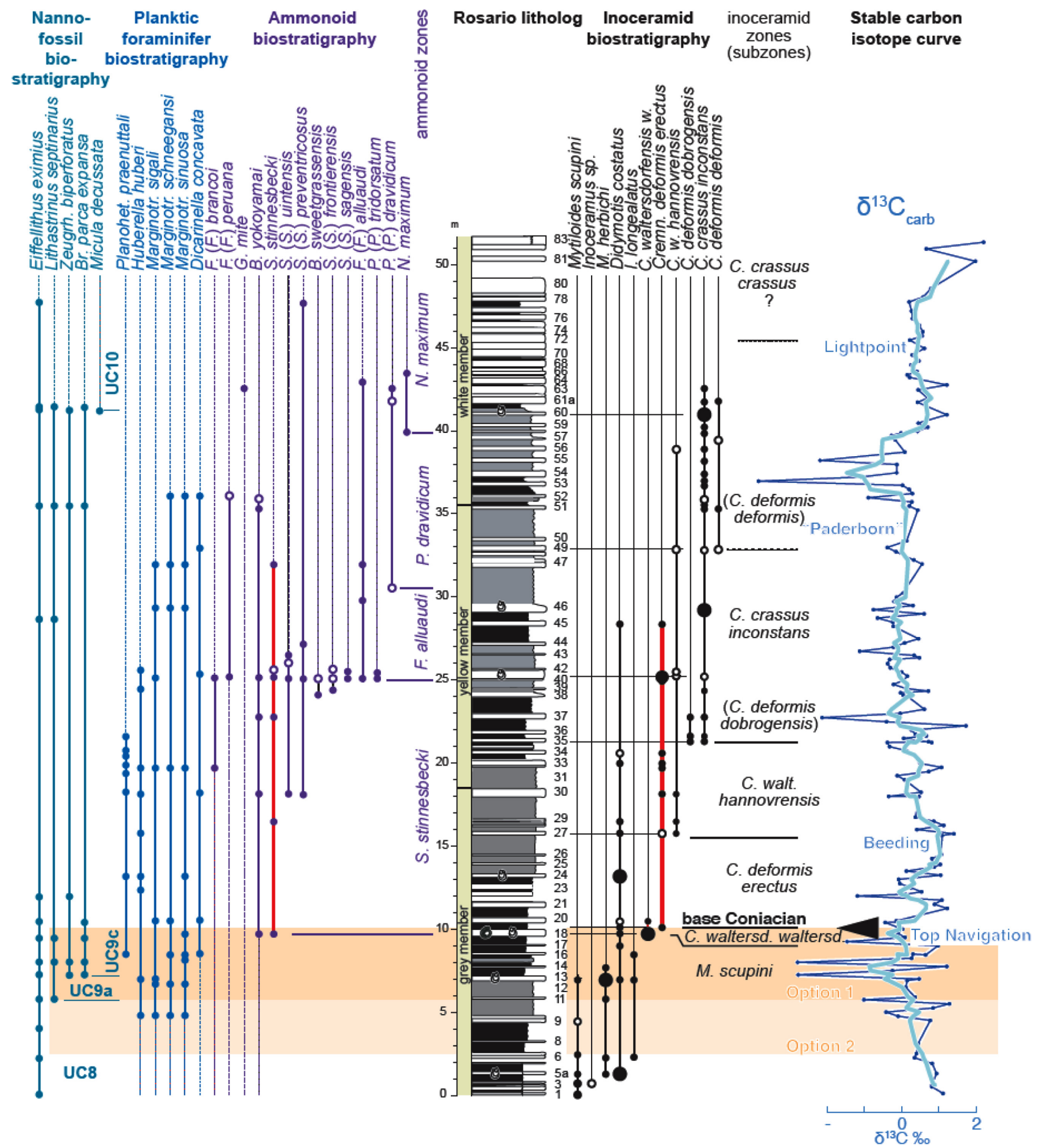

Figure 16. Summary of the El Rosario Turonian-Coniacian boundary section, Coahuila, Mexico. Nannofossil, planktonic foraminifera and ammonoid biostratigraphy with lithostratigraphy, inoceramid biostratigraphy and stable carbon isotope curve and CIEs. Modified from Ifrim et al. (2019) with addition of planktonic foraminifera (Peryt, this paper) and nannofossil records (Linnert, this paper). 
stratotype, and is potentially a good intermediate link for correlation between Europe and the North American Western Interior Basin.

The El Rosario section is situated in the northeastern Mexican state of Coahuila, in Sierra del Carmen National Park (geographic coordinates: $29.0294^{\circ} \mathrm{N},-102.4617^{\circ} \mathrm{W}$ ). It is located in an abandoned quarry, where a sedimentary succession of grey massive, yellow platy and white massive limestone crops out. Fossils are mostly found on bedding surfaces and occur throughout the section, with the exception of the uppermost massive limestone beds. The bio- and chemostratigraphic records are summarized in Fig. 16.

Inoceramid bivalves, occasional oysters, heteromorph and planispiral ammonoids, brachyuran crabs, teleosts, pycnodont sharks, a pterosaur and large marine reptiles are all found in El Rosario (Buchy et al., 2005; Stinnesbecke et al., 2005; Vega et al., 2007; Ifrim et al., 2014). Inoceramids, and to a lesser extent ammonoids, allow for biozonation of the Rosario succession.

\section{Inoceramid biozonation}

The inoceramid zonation in El Rosario was published by Ifrim et al. (2014); it is applied herein with some modification (Fig. 16). The zones are interval zones of the index taxa, with their taxonomic concepts following Walaszczyk and Wood (1998) and Walaszczyk and Cobban (2000).

Eight inoceramid zones are recognized in El Rosario. Moreover, a series of inoceramid and Didymotis bivalve acme occurrences has been recognized. From the base of the succession, these are acme events of: (1) Didymotis (lower acme), in Bed R5a (1.4 m level, M. scupini Zone);

(2) M. herbichi, in Bed R13 (7.0 m level, C. w. waltersdorfensis Zone);

(3) C. w. waltersdorfensis, in Bed R18; (4) Didymotis (upper acme), in Bed R24 (13.3 m level, C. deformis erectus Zone); (5) C. deformis erectus, in Bed R40 (25.0 m level, C. crassus inconstans Zone); (6) C. crassus inconstans (lower acme), in Bed R46 (29.3 m, C. crassus inconstans Zone); and (7) C. crassus inconstans (upper acme), in Bed R60 (41.0 m, C. crassus inconstans Zone).

\section{Ammonite biozonation}

The ammonoids and ammonite-based biozonation in the El Rosario and nearby Carranza successions were discussed by Ifrim et al. (2019); the zonation is a series of interval zones defined by the LOs of their index taxa (Fig. 16).

Scaphites preventricosus, the index zonal marker of the lower Coniacian in the Western Interior (Cobban, 1952; Kennedy and Cobban, 1989; Landman et al., 2016), first appears in Bed R30 where it co-occurs with $S$. (S.) uintensis Cobban. Its LO is thus well above the Turonian-Coniacian boundary as defined by inoceramids. Ammonites indicative of the uppermost Turonian, such as the Western Interior endemic ammonite Scaphites $(S$.) mariasensis Cobban and the widely distributed Euramerican form P. germari have not been observed in El Rosario. Forresteria (Forresteria) peruana - a vicariant species of the European $F$. (H.) petrocoriensis reported from the topmost part of the M. scupini Zone in the US Western Interior (Walaszczyk and Cobban, 2000) only appears in El Rosario in the lower Coniacian C. crassus inconstans Zone. Allocrioceras hazzardi Young, a marker of the early Coniacian in Texas and New Mexico (see Cobban et al., 2008), has not been doc- umented in El Rosario; however, the superficially similar S. stinnesbecki is present in abundance. As such, the LO of this taxon has been proposed as a secondary marker for the base of the Coniacian in northeastern Mexico (Ifrim et al., 2019).

Planktonic foraminifera biozonation (Danuta Peryt): Planktonic foraminifera have been studied from the interval between Beds R10 and R52 (Fig. 16). Most (if not all) of this interval represents the $D$. concavata Interval Zone (Sigal, 1955). Although the LO of the index taxon was recognized in Bed R16, its actual first appearance (FAD) may be lower (the lowest part of the succession is poorly accessible). Dicarinella concavata is known from the upper Turonian of the Tethyan Realm (Robaszynski et al., 1990; Premoli Silva and Sliter, 1995; Robaszynski and Caron, 1995).

Marginotruncana schneegansi (Sigal) (Fig. 9A), M. sigali (Reichel) (Fig. 9B) and M. sinuosa are recorded from the entire interval studied. The most interesting taxon present is $H$. huberi (Figs. 8A-8C), a heterohelicid species, the disappearance (LAD) of which has recently been suggested to be a good foraminiferal proxy for the base of the Coniacian (Georgescu, 2017). In the El Rosario section the species is rare but occurs consistently in the interval between Beds R10 and $\mathrm{R} 42$. Its HO is here located at the boundary between the inoceramid zones of $C$. crassus dobrogensis and C. crassus inconstans, and the base of the $F$. (F) alluaudi ammonite Zone. However, it is important to note that the bad preservation of foraminifera in this succession due to recrystallization, combined with the rarity of $H$. huberi, does not exclude a possible higher occurrence of the species.

Nannofossils (Christian Linnert): The nannofossil analysis presented herein is a preliminary study. Index fossils indicate the presence of nannofossil zones UC8 to UC10 in the El Rosario section. Zeugrhabdotus biperforatus, the FAD of which indicates the base of nannofossil subzone UC9b, first occurs in the uppermost marl of Bed R13 in the same sample as Broinsonia parca expansa, indicative of nannofossil subzone UC9c. This is most probably not indicative of a hiatus, but rather reflective of variable preservation quality. It is notable that the preservation of nannofossils in the lower part of the section is poor, so future studies may show that UC9a, UC9b and/or UC9c should be placed lower in the section.

$\delta^{13} \mathbf{C}_{\text {carb }}$ stratigraphy: The carbon isotope curve from the El Rosario section, related to a set of biostratigraphical datums, allows for a reliable identification of the Turonian-Coniacian boundary CIEs (Fig. 16). A characteristic minimum occurs in Bed $13(-2.8 \%)$ and it is followed by a positive trend with a maximum value of $1.3 \%$ in Bed 27 . This marks the inflection point towards another minimum in the trend $(-2.23 \%)$ in Bed 55, followed by a broad positive peak with values between ca. 0.3 and $1.13 \%$. The Navigation CIE is identified in the topmost Turonian with its top at the Turonian-Coniacian boundary. The Beeding and Lightpoint events of Jarvis et al. (2006) are recognised, as well as the double minimum, informally named the 'Paderborn' Event (Hornacsek and Ifrim, 2017), which is detectable only in high-resolution curves.

\section{Geochronology (Jordan Todes)}

Numerical age estimates for the Turonian-Coniacian boundary have been relatively stable over the past 45 years, with the vast majority 
within an interval of 90-88 Ma (Hallam et al., 1985; Kent and Gradstein, 1985; Gradstein et al., 1994; and citations therein). Since the visionary work of Obradovich (1993), the geochronology of the Upper Cretaceous geological timescale has been in large part based on ${ }^{40} \mathrm{Ar} /{ }^{\beta 9} \mathrm{Ar}$ dating of bentonites within the American Western Interior Basin, correlated inter-regionally via molluscan biostratigraphy (Cobban, 1993; Cobban et al., 2006) and, more recently, chemostratigraphic curves (e.g., Joo and Sageman, 2014). The Turonian-Coniacian boundary is no exception: Obradovich (1993) originally placed the base of the Coniacian at 88.7 $\pm 0.5 \mathrm{Ma}$, which was subsequently updated to $89.3 \pm 1.0 \mathrm{Ma}$ by Cobban et al. (2006). The radioisotopic ages obtained by Obradovich also formed the basis of the 2004 International Geologic Time Scale, where a cubic spline was used to estimate the age of the basal Coniacian as $88.8 \pm 1.0 \mathrm{Ma}$ (Ogg, 2004).

The Upper Cretaceous of the Western Interior Basin is a superb setting to pursue high-resolution geochronological work, due to the existence of: (i) abundant volcanic ash beds with radioisotopically-datable minerals (e.g., zircons, sanidine); (ii) high-resolution lithostratigraphic, biostratigraphic, and chemostratigraphic frameworks allowing for high-resolution correlation within and outside of the Western Interior; and (iii) rhythmic strata interpreted to record orbital cycles, which can thus be employed to create a floating astronomical timescale. Taking advantage of its potential for high-resolution timescale development, Sageman et al. (2014) anchored an astrochronological framework (400 kyr bandpass) for the Niobrara Formation (Turonian-Campanian; Locklair and Sageman, 2008) with new radioisotopic data $\left({ }^{40} \mathrm{Ar} /{ }^{39} \mathrm{Ar}\right.$ and $\mathrm{U}-\mathrm{Pb}$ ) from the Kevin-Sunburst Dome area of Montana; updated biostratigraphic and sequence stratigraphic constraints (e.g., Walaszczyk and Cobban, 1998, 2000; Walaszczyk et al., 2014) enabled inter-regional calibration and hiatus identification. This integrated, multi-faceted approach yielded an age estimate for the base of the Coniacian of $89.75 \pm 0.38 \mathrm{Ma}$. The stage boundary ages put forth by both the Geologic Time Scale 2012 (Ogg et al., 2012) and the Geologic Time Scale 2016 (Ogg et al., 2016) are both essentially derived from Sageman et al. (2014); as such, an age of $89.75 \pm 0.38$ Ma for the Turonian-Coniacian boundary seems to be the consensus in the geological community, and the age accepted by the Coniacian Working Group in this proposal.

It should be noted that the Turonian-Coniacian boundary age proposed in the Geologic Time Scale 2020 (GTS2020) is $89.39 \pm 0.16 \mathrm{Ma}$ (Agterberg et al., 2020; Gale et al., 2020). The uncertainty envelopes of the GTS2020 and Sageman et al. (2014) ages overlap, and thus are not inconsistent with each other; however, it is worth briefly examining the differences between the two approaches. While the GTS2020 Upper Cretaceous spline fit is largely rooted in Sageman et al.'s (2014) radioisotopic dates from the Western Interior Basin, it seems to rely on an extrapolation of the Laskar et al. (2011) orbital solution into the English Chalk (Gale, 2019). The numerical precision of such solutions decreases significantly beyond $50 \mathrm{Ma}$ (Laskar, 2020), rendering them unsuitable for use in chronostratigraphic calibration. By contrast, Sageman et al. (2014) anchored a long eccentricity-based floating astrochronology with five radioisotopic ages, facilitating an internally consistent interpolation of the Turonian-Coniacian boundary age. Beyond that, the durations of Turonian and Coniacian biozones in GTS2020 (Gale et al., 2020, fig. 27.9) differ considerably from other studies (Table 1), and the GTS2020 boundary age is somewhat inconsistent with other Turonian and Coniacian radioisotopic dates (see Sageman et al., 2014). For instance, a radiometrically-dated horizon from the $C$. crassus crassus Zone [Forresteria $(F$.) alluaudi-Scaphites preventricosus ammonite Zone; Sageman et al., 2014] is essentially the same age $(89.37 \pm 0.15 \mathrm{Ma})$ as the GTS2020 Turonian-Coniacian boundary $(89.39 \pm 0.16 \mathrm{Ma})$. The base of the $C$. crassus crassus Zone follows approximately $0.25 \mathrm{myr}$ after the basal Coniacian, according to an astrochronological framework in the Bohemian Cretaceous Basin (Table 1); according to GTS2020 (Gale et al., 2020, fig. 27.9), there should be $\sim 0.80$ myr between them. In light of these considerations, the Sageman et al. (2014) age has been retained here.

As discussed above, a series of studies in the Western Interior Basin have been quite successful in establishing a robust geochronological age for the Turonian-Coniacian boundary - and, more generally, an effective chronostratigraphic framework for the Upper Cretaceous. However, it has proven challenging to assess the timing of the unique sequence of eco-, bio-, and chemostratigraphic events across the TuronianConiacian boundary there, in part due to (i) condensation / hiatuses in the Turonian-Coniacian interval in Pueblo, Colorado (the reference locality for Western Interior biostratigraphy) (Merewether and Cobban, 1986; Walaszczyk and Cobban, 1998; Walaszczyk et al., 2014) and (ii) regional differences, albeit limited, in the biotic evolution of the Turonian-Coniacian boundary interval in the Western Interior versus Europe (Walaszczyk and Cobban, 1998, 2000). These events can, however, be pinned to an orbitally calibrated timescale in the Bohemian Cretaceous Basin. There, the upper Turonian - lower Coniacian consists of a well-defined succession of deltaic sandstones and offshore mudstones that grade into rhythmically bedded hemipelagic strata - ideal for establishing a floating astronomical timescale.

Laurin et al. (2014) developed an orbitally calibrated timescale and linked it to the established chronostratigraphic framework on the western margin of the Bohemian Cretaceous Basin using biostratigraphy and carbon-isotope signatures - in essence calibrating the timing of various eco-, bio-, and chemostratigraphic events relative to the TuronianConiacian boundary. These biostratigraphic datums were then employed to anchor an orbital timescale for the Bch-1 reference core (see Střeleč railway cutting section, Czech Republic, above), which can easily be traced into the well-constrained biostratigraphy of the north-central basin (Laurin et al., 2015). The age model of Bch-1 has been adapted in several studies (Jarvis et al., 2015; Olde et al., 2015a, 2015b; Čech and Uličný, 2021), and a modified version is presented in Table 1.

Voigt et al. (2021) undertook a spectral analysis of the carbon and oxygen isotope data from Salzgitter-Salder, generating a floating cyclostratigraphic timescale for the boundary interval of the Coniacian GSSP (from Bed 35 to Bed 59; Table 1). It should be noted that their spectral periodicities are assumed to represent the short eccentricity $(\sim 100$ $\mathrm{kyr})$ and precessional $(\sim 20 \mathrm{kyr})$ cycles, in reasonable agreement with sedimentation rates estimated for Salzgitter-Salder (Walaszczyk et al., 2010). While the number of macrofaunal ties between Salzgitter-Salder and the Bohemian Cretaceous Basin in the immediate boundary interval is rather limited, due to the absence of well-defined Didymotis (with the exception of Didymotis 0) and erectus bioevents in Bohemia, the carbon isotope and available macrofaunal correlations reflect a relatively good agreement between their respective chronostratigraphic frameworks.

While the Late Cretaceous geologic timescale is primarily anchored by radioisotopic ages from the Western Interior Basin, it is also worth 
Table 1. Summary of chronostratigraphic age models for the Salzgitter-Salder and Bohemian Cretaceous Basin, with key macrofaunal datums noted. The floating ages are relative to the Turonian-Coniacian boundary, with positive ages younger and negative ages older. The floating age model in Salzgitter-Salder is based on Voigt et al. (2021), with macrofaunal biostratigraphy as detailed throughout the present report. The age model of the Bohemian Cretaceous Basin is primarily based on that of Laurin et al. (2015), modified after Jarvis et al. (2015) and Čech and Uličný (2021), with macrofaunal biostratigraphy as detailed in Čech and Uličný (2021). Note that while the micro- and nannofossil (e.g., foraminifera, calcareous nannofossils, dinoflagellate cyst) and chemostratigraphic records from these sections are not included above for the sake of brevity, they can readily be incorporated

\begin{tabular}{|c|c|c|c|}
\hline Stratigraphic Level & $\begin{array}{c}\text { Floating Age } \\
\text { (Salzgitter-Salder) }\end{array}$ & $\begin{array}{l}\text { Floating Age } \\
\text { (Bohemia) }\end{array}$ & $\begin{array}{c}\text { Anchored Age } \\
\text { (Bohemia) }\end{array}$ \\
\hline LO Cremnoceramus crassus crassus & & $250 \pm 52 \mathrm{kyr}$ & $89.50 \pm 0.38,0.05 \mathrm{Ma}$ \\
\hline LO Cremnoceramus crassus inconstans & & $210 \pm 54 \mathrm{kyr}$ & $89.54 \pm 0.38,0.05 \mathrm{Ma}$ \\
\hline erectus III Event & $98 \mathrm{kyr}$ & & \\
\hline LO Cremnoceramus waltersdorfensis hannovrensis & $87 \mathrm{kyr}$ & $39 \pm 31 \mathrm{kyr}$ & $89.71 \pm 0.38,0.03 \mathrm{Ma}$ \\
\hline erectus II Event & $24 \mathrm{kyr}$ & & \\
\hline erectus I Event & $6 \mathrm{kyr}$ & & \\
\hline LO Cremnoceramus deforms erectus & 0 & 0 & $89.75 \pm 0.38 \mathrm{Ma}$ \\
\hline Didymotis II Event & acme: -6 kyr (range: $-9-9$ kyr) & & \\
\hline LO Cremnoceramus waltersdorfensis waltersdorfensis & $-9 \mathrm{kyr}$ & $-9 \pm 24 \mathrm{kyr}$ & $89.76 \pm 0.38,0.02 \mathrm{Ma}$ \\
\hline Didymotis I Event & acme: -86 kyr (range: $-60--123$ kyr) & & \\
\hline LO Mytiloides herbechi & & $-115 \pm 40 \mathrm{kyr}$ & $89.87 \pm 0.38,0.04 \mathrm{Ma}$ \\
\hline Didymotis 0 Event & & $-310--264 \mathrm{kyr}$ & $90.06-90.01 \pm 0.38,0.04 \mathrm{Ma}$ \\
\hline LO Mytiloides scupini & & $-795 \pm 49 \mathrm{kyr}$ & $90.55 \pm 0.38,0.05 \mathrm{Ma}$ \\
\hline
\end{tabular}

discussing the Yezo Group of Hokkaido, Japan, which contains several intercalated felsic tuff beds and horizons suitable for radioisotopic work. In the Ha-1 Unit of the Haborogawa Formation (Turonian-Campanian), the Turonian-Coniacian boundary is placed in the middle of the Navigation CIE, their NP-18 event (as determined by a $\delta^{13} \mathrm{C}_{\text {org }}$ curve, reinforced by the appearance of several key biostratigraphic markers) (Takashima et al., 2010, 2019). Of particular interest to this report is the presence of a thick tuff, essentially located on the Turonian-Coniacian boundary, which is widely traceable for hundreds of kilometres across Hokkaido (Takashima et al., 2019; Kuwabara et al., 2019). The $\mathrm{U}-\mathrm{Pb}$ radiometric age of this horizon is $89.94 \pm 0.98 \mathrm{Ma}-$ essentially indistinguishable from the consensus age of the Turonian-Coniacian boundary (Kuwabara et al., 2019). This is a particularly significant result because it suggests the Turonian-Coniacian boundary was accurately placed via chemostratigraphic means (e.g., Takashima et al., 2010, 2019; Hayakawa and Hirano, 2013), which would in turn suggest that the base of the Coniacian should be within the Inoceramus uwajimensis Zone, not at the base of the zone as traditionally interpreted (e.g., Toshimitsu et al., 2007, and references therein; see also below).

\section{Correlations}

The biostratigraphic markers used to recognise the base of the Coniacian - and more broadly, those useful in the Turonian-Coniacian boundary interval - are largely recognisable across the entire Euramerican Biogeographic Province, which renders identification and correlation a relatively straightforward task. Typically, the best represented marker is the LO of Cremnoceramus deformis erectus, the primary marker of the boundary, which usually occurs in a quite distinct succession: M. herbichi - C. w. waltersdorfensis $-C$. deformis erectus. This succession, and C. deformis erectus in particular, have been documented from Mangyshlak in western Kazakhstan (Marcinowski et al., 1996; Walaszczyk et al., 2013), the Caucasus and Crimea (Kopaevich and Walaszczyk, 1990), the Cretaceous of Saratov (Walaszczyk, unpublished) and Briansk (Walaszczyk et al., 2004), across central and western Europe (e.g., Walaszczyk and Wood, 1998; Wood et al., 2004; Walaszczyk et al., 2010; Walaszczyk, 1992, 2000; and references therein), the Gulf Coast Subprovince (Texas, Hancock and Walaszczyk, 2004; northeastern Mexico, Ifrim et al., 2014, 2019), and from the US Western Interior (Walaszczyk and Cobban, 1998, 2000; Cooper et al., 2017). It has also been documented in the Tethyan Realm: for example in Romania (Pauliuc, 1968, Szasz, unpublished); Bulgaria (Dochev and Granchovski, 2017); Sardinia (Walaszczyk, 2000), and from the South Atlantic Subprovince (Brazil, Kauffman and Bengtson, 1985 and partly documented in Nigeria; Gebhardt, 2001, 2010).

However, there are several regions for which direct biostratigraphic correlation, using the primary or any of the secondary markers, is more complex. These are the North Pacific Province, the East African Province/Subprovince, and New Zealand.

\section{North Pacific Province (Ireneusz Walaszczyk)}

In the traditional biostratigraphic scheme of the North Pacific Upper Cretaceous, the base of the Coniacian has long been placed at the base of the Inoceramus uwaijmensis Zone (e.g., Matsumoto, 1984; Zonova in Poyarkova, 1987; Toshimitsu et al., 1995, 2007; Matsumoto and Noda, 1999; Zonova and Yazykova, 2008). However, as noted above, recent chemostratigraphic correlations (Takashima et al., 2010, 2019; Hayakawa and Hirano, 2013; Jarvis et al., 2015) suggest that this boundary lies within the I. uwajimensis Zone, not at its base as previously assumed.

The new correlation is also supported biostratigraphically. The ammonites Kossmaticeras theobaldianum, Forresteria alluaudi, and 
Barroisiceras onilahyense, and the characteristic bivalve genus Didymotis (with the species D. costatus) reported by Takashima et al. (2019) from an interval spanning the Turonian-Coniacian boundary, as here interpreted, represent a characteristic Turonian-Coniacian boundary assemblage. A preliminary study of the 'Inoceramus rotundatus' of Matsumoto and Noda (1985), based on the originals from the Kyushu University Museum (Walaszczyk, unpublished), showed that they represent at least two different species, distinct from both the original concept of Fiege (1930) and from rotundatus sensu Tröger (1967). Both Japanese morphotypes are definitely late Turonian taxa.

\section{East African Province/Subprovince (Ireneusz Walaszczyk)}

The Turonian-Coniacian boundary succession in the East African Province is known from Magadascar, South Africa and the Cauvery Basin of southeastern India. The best record is known from the Onilahy on Manasoa section, SW Madagascar, which provides rich ammonite and inoceramid assemblages that spans the boundary interval (Walaszczyk et al., 2004, 2014a). The Onlilahy succession is supplemented by data from the Cauvery Basin, SE India, which has yielded specimens of $C$. deformis erectus in addition to the typical East African ammonite/ inoceramid assemblages (see Walaszczyk et al., 2018).

In the East African Province, the base of the Coniacian is placed at the first occurrence of the inoceramid species Tethyoceramus madagascariensis (Heinz) (Walaszczyk et al., 2004). As a genus, the Tethyoceramus clade ranges from the latest Turonian through most of the early Coniacian, and intriguingly mirrors the stratigraphic range of Cremnoceramus in the Euramerican Province (see Walaszczyk et al., 2004). The correlation to the Euramerican inoceramid succession is based on: (1) the high level of evolutionary parallelism between the Tethyoceramus and Cremnoceramus clades; (2) the chronostratigraphic dates of $B$. onilahyense and of $K$. $(K$.) theobaldianum, ammonites found in Onilahy and known from the Turonian-Coniacian boundary interval outside the province; (3) the record of $C$. deformis erectus from the $T$. madagascariensis assemblage in India; and (4) the appearance of Tethyoceramus within the Cremnoceramus-dominated fauna interval of the Euramerican Biogeographic Region.

\section{Recognition of the Turonian-Coniacian boundary in New Zealand (James Crampton and Poul Schiøler)}

Correlations between New Zealand Cretaceous strata and the international geological timescale are problematic because of the endemism of New Zealand macrofaunas and the paucity of ammonites in New Zealand successions. The generally non-calcareous nature of New Zealand strata means that calcareous microfossils tend to occur in low abundance and low diversity, and suffer from low recovery and poor preservation. Furthermore, calcareous microfossils undoubtedly exhibit diachroneity from well-studied mid- to low-palaeolatitude sites into southern high latitudes, although the details of biogeographic variation in the timings of first- and last-occurrences remain poorly known (e.g., Petrizzo et al., 2020). For these reasons, over the past century New Zealand geoscientists have erected a regional geological timescale based mainly on local macrofossils, mostly inoceramid bivalves, and this timescale remains the key framework for dating and correlating local strata (see discussion in Cooper, 2004).
Existing correlations indicate that the Turonian-Coniacian boundary lies within the lower part of the local Teratan Stage of the Raukumara Series (Crampton et al., 2001, 2004a; Raine et al., 2015). This stage is defined using the first occurrence of an inoceramid bivalve, Inoceramus opetius Wellman, in the Mangaotane Stream section, North Island (stage defined originally by Wellman, 1959, and revised by Crampton, 1996; Crampton et al., 2001; Crampton and Schiøler, 2019). This section is the most continuous and best-studied section through the lower half of the Upper Cretaceous in New Zealand and, in addition to the Teratan Stage, it contains the boundary stratotypes for the underlying Arowhanan and Mangaotanean stages (Wellman, 1959; Crampton et al., 2001, 2004a; Crampton and Schiøler, 2019).

New Zealand Cretaceous inoceramid bivalves are apparently largely endemic at the species level (Crampton, 1996). In addition, some key genera seem to appear one or two stages earlier in the New Zealand region than in Europe and North America. Examples include the Albian appearance of Mytiloides in New Zealand (Crampton, 2004; Crampton et al., 2004b) and the basal Turonian appearance of Cremnoceramus in New Zealand, which is used to define the Mangaotanean Stage (Crampton, 1996). For this reason, correlations with the international time scale based on inoceramids are problematic, although it seems that the lowest occurrence of at least one species - Inoceramus? nukeus (Wellman) - may provide a valuable southern high latitude marker for the late Turonian (see below).

Although inoceramid bivalves remain the key to the definition and local correlation of most New Zealand Cretaceous stages, organic walled dinoflagellate cyst microfloras have also been used widely for local correlation and are becoming an increasingly important tool for correlating to the international timescale (e.g., Wilson, 1984; Roncaglia et al., 1999; Hasegawa et al., 2013; Schiøler and Crampton, 2014; and herein). Most of the dinoflagellate taxa that occur through the Mangaotanean and Teratan Stages are well known and recorded from sections in Australia and Antarctica (e.g., Morgan, 1980; Marshall, 1984; McMinn, 1988; Helby et al., 1987; Riding et al., 1992; Barreda et al., 1999; Riding and Crame, 2002). Correlation with the Australian dinoflagellate zonation of Helby et al. (1987), which is used widely as a reference in Australasia and Antarctica, is mostly straightforward. The calibration of the Turonian-Coniacian interval in the Helby et al. zonation to the international standard is based primarily on nannofossils and foraminifera, although correlations have been updated based on strontium isotopes from sections in Antarctica (McArthur et al., 2000; Riding and Crame, 2002).

Correlation of dinoflagellate floras to sections in Europe is less straightforward due to a much lesser degree of species overlap between the regions. However, recent work on the dinoflagellate biostratigraphy of the Cenomanian-Santonian interval in European sections (Olde et al., 2015a; Pearce et al., 2020; Jarvis et al., 2021) has added new data and better time control to the interval. For example, Pearce et al. (2020) synthesised available dinoflagellate data and suggested a list of 65 events through the interval, some of which are considered to have worldwide significance. These events were, in turn, calibrated using radioisotopic and astrochronological ages of macrofossil biostratigraphic datums, global carbon-isotope excursions, and the base Chron C32 geomagnetic reversal (Pearce et al., 2020). Two events from the European sections have been used herein in an attempt to achieve long-distance correlation. 


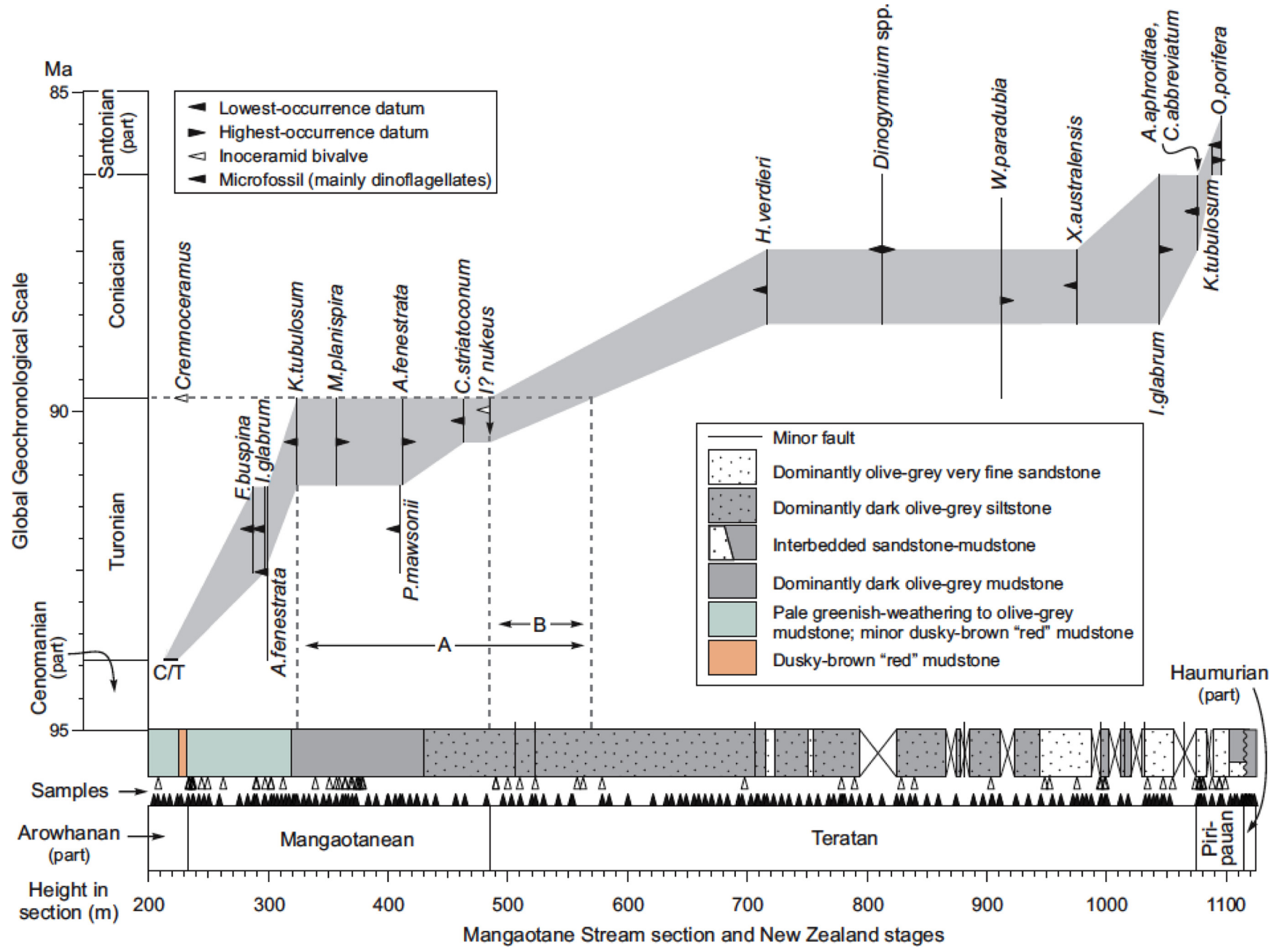

Figure 17. Age-depth plot for the Upper Cretaceous Mangaotane Stream section, New Zealand, showing key criteria that are useful for correlating to the international time scale. Each of these criteria is discussed briefly in the text. Arrowheads that are used to denote lowest- and highest-occurrence datums indicate expected movements of those datums down- and up-section, respectively, in response to future improvements in sampling and biostratigraphic characterisation of the section. Uncertainties on the ages of particular biostratigraphic events assume that "lower", "middle" and "upper" divisions are of equal duration for each of the Turonian and Coniacian stages. The grey polygon indicates the limits within which the age-depth curve must lie. "A" indicates the interval in Mangaotane Stream that must contain the TuronianConiacian boundary; " $B$ " indicates the most likely boundary interval. According to this, the Turonian-Coniacian boundary is within the lowest part of the Teratan Stage. The Mangaotane Stream measured section is simplified from Crampton and Schioler (2019), and details of samples may be found in that publication.

Correlation between the New Zealand and international time scales for the interval spanning the Turonian and Coniacian stages is shown by way of an age-depth plot for the Mangaotane Stream section (Fig. 17). Key biostratigraphic data and age constraints are explained below, in ascending stratigraphic order. These data suggest that the TuronianConiacian boundary lies within the lowest part of the Teratan Stage in the Mangaotane section. The identification of biostratigraphic events in the section follows Crampton et al. (2001), Schiøler and Crampton (2014), Crampton and Schiøler (2019), unpublished reports by G.J. Wilson, and ongoing, unpublished work on the section by the present authors. The stratigraphic placement of all events and samples follows the recent compilation and recalibration of section heights to a common scale, as explained in Crampton and Schiøler (2019); that publication also amended the position of the boundary stratotype for the Teratan Stage.
1. The position of the Cenomanian-Turonian boundary ("C/T" on Fig. 17) is based on correlations of dinoflagellate floras and the (somewhat equivocal) carbon isotope signal, as reported in Hasegawa et al. (2013) and Schiøler and Crampton (2014), and is located within the interval 213-224 m.

2. The lowest occurrence (LO) of the dinoflagellate Florentinia buspina (Davey and Verdier) Duxbury is middle Turonian according to Davey and Verdier (1976) and Olde et al. (2015a) and occurs at $288 \mathrm{~m}$.

3. The LO of the dinoflagellate Isabelidinium glabrum (Cookson and Eisenack) Lentin and Williams is at $297 \mathrm{~m}$ and is middle Turonian according to Helby et al. (1987).

4. The dinoflagellate Aiora fenestrata Cookson and Eisenack also has an LO at $297 \mathrm{~m}$. This taxon is restricted to the Turonian Stage according to Marshall (1984), and here we assume that its LO lies within the lower to middle Turonian and its HO lies within the upper 
Turonian (see below).

5. The LO of the dinoflagellate Kleithriasphaeridium tubulosum (Cookson and Eisenack) Stover and Evitt is at $324 \mathrm{~m}$ and is upper Turonian according to Marshall (1984) and Helby et al. (1987).

6 . The highest occurrence (HO) of the planktonic foraminifera Muricohedbergella planispira Tappan is at about $357 \mathrm{~m}$ and is upper Turonian according to Robaszynski and Caron (1979). It is important to note, however, that the biostratigraphic range is in need of revision.

7. The LO of the miospore Phyllocladidites mawsonii Cookson, the index for the P. mawsonii Zone, is at $412 \mathrm{~m}$ and is mid-Turonian in New Zealand (Raine, 2014).

8. The HO of $A$. fenestrata, also at $412 \mathrm{~m}$, is assumed to lie within the middle to upper Turonian, based on Marshall (1984), but this stratigraphic range can be further restricted to upper Turonian since the event lies below the LO of the dinoflagellate Conosphaeridium striatoconum (Delandre and Cookson) Cookson and Eisenack (Marshall, 1984; Riding and Crame, 2002; and herein), an uppermost Turonian event (see event 9 below), and above the LO of Kleithriasphaeridium tubulosum (Cookson and Eisenack) Stover and Evitt, an upper Turonian event (see event 5 above).

9. The $\mathrm{LO}$ of C. striatoconum is at $464 \mathrm{~m}$ and occurs in the uppermost Turonian (McMinn, 1988; Riding et al., 1992; Riding and Crame, 2002).

10. The LO of the inoceramid I.? nukeus, at $485 \mathrm{~m}$, is coincident with the base of the Teratan Stage (defined by the LO of the inoceramid $I$. opetius). Inoceramus nukeus was formerly referred to T. madagascariensis by Crame (1981) and Crampton (1996), but apparently represents a distinct form (Walaszczyk et al., 2004) that is widespread in southern high palaeolatitudes, including New Zealand, Patagonia, and the Antarctic Peninsula (Crampton, 1996). On the basis of strontium isotopes, McArthur et al. (2000) inferred that the LO of this inoceramid is at least as old as latest Turonian on the Antarctic Peninsula, although the presence of an unconformity within their section means that the FAD could not be determined (uncertainty indicated by an arrowhead on Fig. 17).

11. The joint LO, influx and persistent abundance up-section of the dinoflagellate Heterosphaeridium sp. of Schiøler and Wilson (1998), now considered conspecific with Heterosphaeridium verdieri Yun Hyesu, at $716 \mathrm{~m}$, is correlated with the influx and proliferation of $H$. verdieri in northwestern Europe, an event that was dated as mid-Coniacian ( $88 \mathrm{Ma}$ ) by Pearce et al. (2020).

12. The LO of the dinoflagellate genus Dinogymnium is at $812 \mathrm{~m}$ and is a mid- to upper Coniacian event (Helby et al., 1987; Riding and Crame, 2002).

13. The HO of the planktonic foraminfera Whiteinella paradubia Sigal is at $911 \mathrm{~m}$ and occurs in the interval 89.9-86.7 Ma according to the online mikrotax database (pforams@mikrotax database: Huber et al., 2016, accessed on $20^{\text {th }}$ May 2020). Again, the biostratigraphic range of this species may require revision.

14. The LO of the dinoflagellate Xenascus australensis Cookson and Eisenack is at $975 \mathrm{~m}$ and is a mid-Coniacian event according to Marshall (1984).

15. The HO of I. glabrum, at $1046 \mathrm{~m}$, is a mid- to upper Coniacian event according to Helby et al. (1987).

16. The LO of the dinoflagellate Actinotheca aphroditae Cookson and Eisenack is at $1076 \mathrm{~m}$ and occurs in the upper Coniacian accord- ing to Helby et al. (1987) and McMinn (1988).

17. The LO of the dinoflagellate Conosphaeridium abbreviatum Wilson, is upper Coniacian (Schiøler and Wilson, 1998) and occurs at $1076 \mathrm{~m}$. Note that an apparent decrease in sedimentation rate in this part of the Mangaotane section probably reflects omission of strata along one or more normal faults (see geological map in Crampton et al., 2001; Crampton and Schiøler, 2019).

18. The HO of the dinoflagellate K. tubulosum at $1088 \mathrm{~m}$ is thought to be in the lowermost Santonian (Helby et al., 1987).

19. The LO of the dinoflagellate Odontochitina porifera Cookson is in the lower Santonian (Helby et al., 1987; Marshall, 1984) and occurs at $1096 \mathrm{~m}$.

\section{Conclusions}

The Salzgitter-Salder section is the Global Boundary Stratotype Section (GSSP) for the base of the Coniacian Stage. The boundary interval is part of an extensive upper Turonian-lower Coniacian succession that is well exposed and apparently continuous. The previously suggested hiatus at the boundary level was based on an interpretation of the then-available inoceramid and carbon isotope records, and does not appear to pose an issue at present. New inoceramid and carbon isotope records indicate that the boundary interval is continuous and complete, although slight condensation is possible at the very base of the Coniacian (Bed 46). The degree of condensation, however, can easily be estimated based on a comparison with Słupia Nadbrzeżna, one of the auxiliary sections. The succession is composed of uniform limestone / marly limestone / marl alternations, with common to abundant critical groups of macrofossils (inoceramids) and microfossils (planktonic and benthic foraminifera, nannofossils and organic-walled dinoflagellate cysts), and a good and reliable carbon isotope signal. The integrated bio- and chemostratigraphic records derived from Salzgitter-Salder (Figs. 18, 19) allow for well constrained long-distance correlations.

The base of the Coniacian Stage is defined by the first occurrence of the inoceramid Cremnoceramus deformis erectus (Meek), and is placed at the base of Bed 46. [Note that this is one bed below Bed 47, which was formerly regarded as the entry level of $C$. deformis erectus and thus the base of the Coniacian Stage]. The first appearance of $C$. deformis erectus follows shortly after the first appearance of its evolutionary predecessor, C. waltersdorfensis waltersdorfensis, which marks the main turnover event in the evolutionary history of the clade around the base of the Coniacian.

There is, in addition, a series of secondary stratigraphic markers surrounding the base of the Coniacian in the Salzgitter-Salder section, plus two important markers [lowest appearances of the ammonite Forresteria $(\mathrm{H}$.) petrocoriensis and of the planktonic foraminifera Dicarinella concavata) which can be projected from the boundary auxiliary sections]. From lowest to highest (stratigraphically) the primary and secondary markers are (Fig. 19):

Beds 35b-36: Two positive carbon isotope peaks, referred to collectively as the 'i5' Event.

Beds 39b-45b: A negative $\delta^{13} \mathrm{C}$ excursion, the Navigation Carbon Isotope Event (CIE) Option 2.

Bed 39b: The lower acme occurrence of the bivalve genus Didymo- 


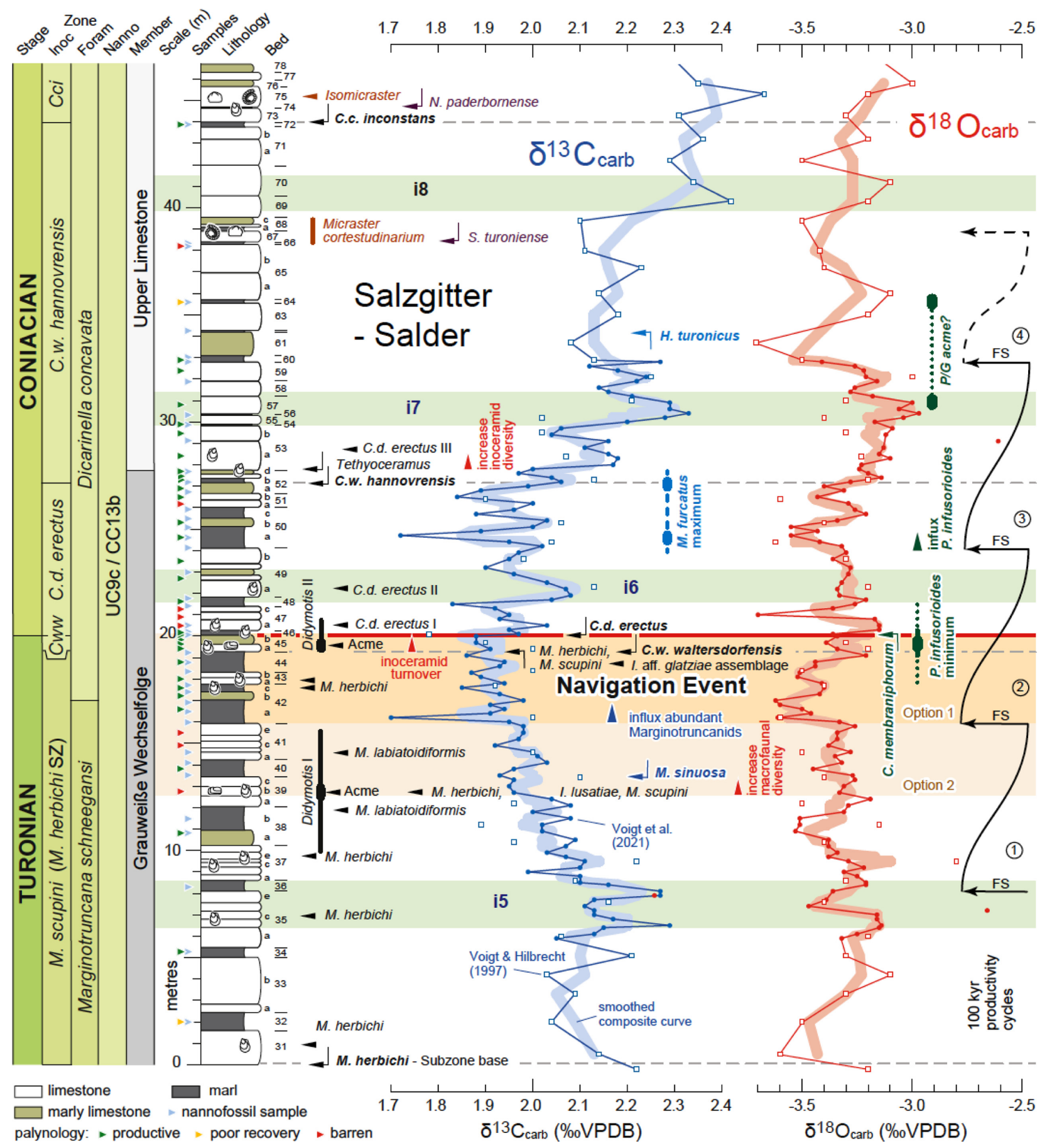

Figure 18. Stratigraphy, stable-isotope profiles, cyclicity, and the primary and secondary markers of the Turonian-Coniacian boundary succession at Salzgitter-Salder. Members are subunits of the Erwitte Formation, Upper Plänerkalk Group (Niebuhr et al. 2007). Bed numbers and lithostratigraphic log modified from Wood et al. (1984) and Wood and Ernst (1998), with location of palynology (pale blue arrows) and calcareous nannofossil samples (green, yellow, red 'traffic light' arrow scheme) of Jarvis et al. (2021). Records of stratigraphically significant macrofossil occurrences (compiled from Raseman, 1984; Wood et al. 1984; Kauffman et al. 1996; Walaszczyk and Wood 1998; Wood and Ernst 1998; Walaszczyk et al. 2010; Čech and Uličný 2021; Voigt et al. 2021), with key lowest and highest occurrence datum levels, are inoceramids (black symbols and names), echinoids (brown), and ammonites (purple). Cww-Cremnoceramus walterdorfensis walterdorfensis, Cci-Cremnoceramus crassus inconstans. Note multiple beds with Mytiloides herbichi in the Upper Turonian, and the Turonian-Coniacian boundary defined by the lowest occurrence and first appearance datum level of Cremnoceramus deformis erectus in Bed 46. Isotope data from Voigt and Hilbrecht (1997) and Voigt et al. (2021). Carbon isotope events (CIEs, green and beige horizontal bars) modified from Jarvis et al. (2006, 2015), Pearce et al. (2020) and Voigt et al. (2021). Options 1 and 2 are alternative definitions of the Navigation CIE (see Voigt et al. 2021 and text). Key planktonic foraminifera (dark blue symbols and names; after Peryt in Walaszczyk et al. 2010), nannofossil (medium blue) and dinocyst (green) marker datum levels (Jarvis et al. 2021; Voigt et al. 2021) are indicated. The entire succession lies within Upper Cretaceous nannofossil zone $U C 9 c$ and nannofossil zone CC13b (see text). $100 \mathrm{kyr}$ progradational cycles derived from spectral analysis of $\delta^{13} C_{\text {carb }}$ and $\delta^{18} O$ curves and lithology (cycles 1-3) or lithology alone (cycle 4), after Voigt et al. 2021. FS =flooding surface. Modified from Jarvis et al. (2021). 


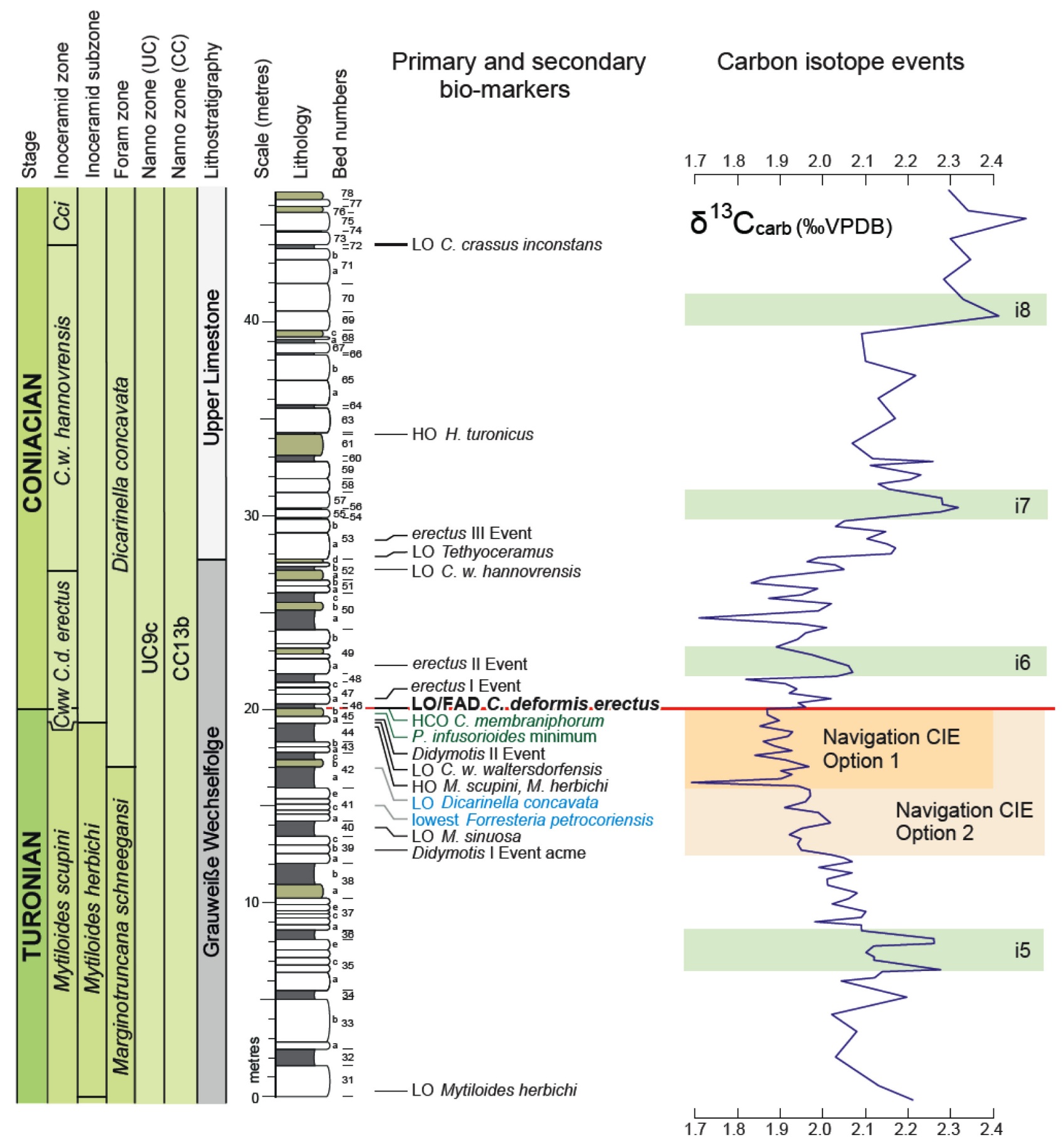

Figure 19. The sequence of the primary and secondary boundary markers across the Turonian-Coniacian boundary interval in the Salzgitter-Salder section, the stratotype for the base of the Coniacian Stage. Green are dinocyst markers; HCO - highest consistent occurrence. In blue are secondary markers projected from the El Rosario and Slupia Nadbrzeżna auxiliary sections.

tis, which is the Didymotis I Event.

Bed 41: The lowest occurrence (LO) of Forresteria (Harleites) petrocoriensis (projected from the Słupia Nadbrzeżna auxiliary section).

Bed 42: The lowest occurrence (LO) of Dicarinella concavata (projected from the El Rosario and Słupia Nadbrzeżna auxiliary sections).

Beds 42a-45b: The Navigation Carbon Isotope Event (CIE) (Option 1).

Bed 44: The highest occurrences (HO) of Mytiloides herbichi and
Mytiloides scupini.

Bed 45a. The lowest occurrence (LO) of Cremnoceramus waltersdorfensis waltersdorfensis and the Didymotis II Event. Core of an interval with a relative abundance minimum of Palaeohystrichophora infusorioides.

Bed 46: The lowest occurrence (LO) / first appearance datum (FAD) of Cremnoceramus deformis erectus; the base of the Coniacian Stage. Top of the Navigation Carbon Isotope Event. Highest consistent occurrence (HCO) of Cyclonephelium membraniphorum. 
Bed 47a: The lowest acme occurrence of Cremnoceramus deformis erectus, which is the erectus I Event.

Bed 49a: A higher acme occurrence of Cremnoceramus deformis erectus, which is the erectus II Event; the 'i6' Event, a positive carbon isotope excursion.

Bed 52b: The lowest occurrence (LO) / the first appearance datum (FAD) of Cremnoceramus waltersdorfensis hannovrensis.

Bed 53a: The third acme occurrence of Cremnoceramus deformis erectus, which is the erectus III Event.

Bed 55-58: The 'i7' Event, a positive carbon isotope excursion.

Bed 62: The highest occurrence (HO) of Helicolithus turonicus.

Beds 69-70: The 'i8' Event, a positive carbon isotope excursion.

Bed 73: The lowest occurrence (LO) / likely the first appearance datum (FAD) of Cremnoceramus crassus inconstans.

The auxiliary sections for the base of the Coniacian Stage are Slupia Nadbrzeżna, the Střeleč railway cutting section, and the EI Rosario section. The Słupia Nadbrzeżna section provides an excellent inoceramid record across the boundary interval, allowing for high-resolution correlation to the Salzgitter-Salder section, and demonstrates that the ammonite Forresteria $(H$.) petrocoriensis first enters the stratigraphic record in the upper Turonian, which may be projected to Bed 41 of the Salzgitter-Salder section. It additionally documents the latest Turonian lowest occurrence of the planktonic foraminifera Dicarinella concavata, which can be projected to Bed 42 of the Salzgitter-Salder section.

In the Střeleč railway cutting, the biostratigraphic and chemostratigraphic records are shown to be faithfully recorded in a depositional system influenced by substantial terrigenous clastic input.

Finally, the El Rosario section provides a rich record of the ammonite succession (which is rather sparse in the Salzgitter-Salder section) and demonstrates the presence and chronostratigraphic validity of most of the bio- and isotopic events recognized in Salzgitter-Salder also in North America. It documents the uppermost Turonian lowest occurrence of the planktonic foraminifera Dicarinella concavata, which can be projected to Bed 42 of the Salzgitter-Salder section. Moreover, it shows that the LAD of Huberella huberi, the suggested foraminiferal proxy for the base of the Coniacian, is distinctly younger than the basal Coniacian, and is at least as young as the base of the Forresteria (F.) allaudi ammonite Zone and a mid-level of the Cremnoceramus crassus inconstans inoceramid Zone.

\section{Acknowledgments}

We thank: Jochen Erbacher, for his efforts and arrangements concerning the protection of our main locality, the Salzgitter-Salder section; Birgit (Sarah) Niebuhr, for comments on the geology of the area and help with necessary literature; Holger Gebhardt (Geological Survey of Austria, Vienna), Wojtek Kozłowski (University of Warsaw), and Jiří Laurin (Institute of Geophysics, Czech Academy of Sciences), for comments on the earlier drafts and / or consultation on specific topics; Bruno Granier, Brian Huber, Takashi Hasegawa, and Michael Wagreich, Voting Members of the International Subcommission on Cretaceous Stratigraphy, for comments which helped to improve the final version of the proposal; Angela Coe (Chair of the International Subcommis- sion on Jurassic Stratigraphy) and Laia Alegret (Chair of the International Subcommission on Paleogene Stratigraphy) for their comments during the discussion of the proposal by ICS. Special thanks go to Maria Rose Petrizzo, Chair of the International Subcommission on Cretaceous Stratigraphy, for comments and constant support. David Harper and Phil Gibbard, Chair and the Secretary-General of the International Commission on Stratigraphy, and Jin-Yong Lees, Episodes Editor-in-Chief, made valuable comments on the final version of the manuscript. We also acknowledge financial support by the International Subcommission on Cretaceous Stratigraphy (http://cretaceous.stratigraphy.org/).

Christina Ifrim thanks Wolfgang Stinnesbeck for 15 years of joint study on the El Rosario section, Arturo H. González González and José Manuel Padilla (Museo del Desierto, Saltillo, Coahuila, Mexico) for access to the CPC collection and help in the field, Melanie Kling (Heidelberg) for field assistance, and Rodrigo González González and CEMEX Mexico for help with field logistics. The financial support of the German Science Foundation to Christina Ifrim (DFG project IF61/11-1 and STI128/40/1), of Evolution Applied Limited to MAP, and Equinor Energy AS (previously Statoil ASA) to Ian Jarvis (contract 4502311303) is gratefully acknowledged. James S. Crampton and Poul Schiøler acknowledge the use of palynological samples that were prepared by GNS Science (Lower Hutt, New Zealand). David Uličný and Stanislav Čech acknowledge support by the Czech Science Foundation (GAČR), grant No. 17-10982S, and by the Czech Academy of Sciences through Programme 67985530. Irek Walaszczyk acknowledges the financial support of the Polish National Science Centre (NCN) through grant no. 2018/31/B/ST10/01820.

\section{References}

Agterberg, F.P., Da Silva, A.-C., and Gradstein, F.M., 2020, Chapter 14, Geomathematical and statistical procedures. In: Gradstein, F.M. et al. (Eds.), Geologic Time Scale, Elsevier, pp. 402-439.

Andrade, E.J., 2005, Turonian inoceramids and biostratigraphy of the Sergipe Basin, northeastern Brazil: an integrated study of the Votorantim and Nassau quarries, 155 pp. University of Heidelberg, Heidelberg. [Unpublished $\mathrm{PhD}$ thesis]

Baldschuhn, R., and Kockel, F., 1998, Der Untergrund von Hannover und seiner Umgebung. Bericht der Naturhistorischen Gesellschaft Hannover, v. 140, pp. 5-98.

Barreda, V., S. Palamarczuk, S., and Medina, F., 1999, Palinología de la Formación Hidden Lake (Coniaciano-Santoniano), Isla James Ross, Antártida. Revista Española de Micropaleontología, v. 31, pp. 53-72.

Basse, E., 1947, Paléontologie de Madagascar 26. Les peuplements Malgaches de Barroisiceras (Révision du genre Barroisiceras de Gross). Annales de Paléontologie, v. 33, pp. 97-178.

Beniamovski, V.N., 2008, Infrazonal biostratigraphy of the Upper Cretaceous in the East European Province based on benthic foraminifers, Part 1: Cenomanian-Coniacian. Stratigraphy and Geological Correlation, v. 16, pp. 257-266.

Bräutigam, F., 1962, Zur Stratigraphie und Paläontologie des Cenomans und Turons im nordwestlischen Harzvoland. University of Braunschweig, Braunschweig. [Unpublished Ph.D. thesis]

Buchy, M.-C., Smith, K.T., Frey, E., Stinnesbeck, W., González González, A.H., Ifrim, C., López-Oliva, J.G., and Porras-Muzquiz, H., 2005, Annotated catalogue of marine squamates (Reptilia) from the Upper Cretaceous of northeastern Mexico. Netherlands Journal of Geosciences Geologie en Mijnbouw, v. 84, pp. 195-205. 
Burnett, J.A., Gallagher, L.T., and Hampton, M.J., 1998, Upper Cretaceous. In: P.R. Bown (Ed.), Calcareous Nannofossil Biostratigraphy. British Micropalaeontological Society Series, Chapman Hall/Kluwer Academic Press, pp. 132-199.

Carter, D.J., and Hart, M.B., 1977, Aspects of mid-Cretaceous stratigraphical micropalaeontology: Bulletin of the British Museum (Natural History), Geology, v. 29, pp. 1-135.

Čech, S., 2009, Preliminary results of the borehole V 800 Střeleč (Bohemian Paradise Geopark, Bohemia). Sborník Muzea Českého ráje, v. 4 , pp. 39-44. [In Czech with English abstract].

Čech, S. (Ed.), 2011, Explanatory notes to the Basic Geological Map, scale 1:25 000, sheet 14-343 Svitavy. Česká geologická služba, 76 p. [In Czech with English résumé].

Čech, S. (Ed.), 2013, Explanatory notes to the Basic Geological Map, scale 1:25 000, sheet 03-342 Rovensko pod Troskami, Česká geologická služba, 176 p. [In Czech].

Čech, S., and Švábenická, L., 1992, Macrofossils and nannofossils of the type locality of the Březno Formation (Turonian-Coniacian, Bohemia). Věstník Českého geologického ústavu, v. 67, pp. 311-326.

Čech, S., and Uličný, D., 2021, The Turonian-Coniacian stage boundary in an expanded siliciclastic succession: integrated stratigraphy in deltaic through offshore facies, Bohemian Cretaceous Basin. Cretaceous Research, v. 117, 104576, doi.org/10.1016/j.cretres.2020.104576

Čech, S., Klein, V., Kř́̌ž, J., and Valečka, J., 1980, Revision of the Upper Cretaceous stratigraphy of the Bohemian Cretaceous Basin. Věstník Ústředního Ústavu geologického, v. 55, pp. 277-296.

Čech, S., Rejchrt, M., and Štaffen, Z., 2011, Cretaceous sediments in borehole V 800 Střeleč, their petrography, lithostratigraphy and chemostratigraphy. Zprávy o geologických Výzkumech v Roce 2010, pp. 14-19. [In Czech with English abstract].

Cobban, W.A., 1952, Scaphitoid cephalopods of the Colorado Group. United States Geological Survey Professional Paper, v. 239, pp. 1-42.

Cobban, W.A., 1993, Diversity and distribution of Late Cretaceous ammonites, Western Interior, United States. In: Caldwell, W.G.E., and Kauffman, E.G. (Eds.), Evolution of the Western Interior Basin: Geological Society of Canada Special Paper, v. 39, pp. 435-451.

Cobban, W.A., Walaszczyk, I., Obradovich, J.D., and McKinney, K.C., 2006, A USGS Zonal Table for the Upper Cretaceous Middle Cenomanian-Maastrichtian of the Western Interior of the United States Based on Ammonites, Inoceramids, and Radiometric Ages (USGS Numbered Series No. 2006-1250), Open-File Report.

Cobban, W.A., Hook, S.C., and McKinney, K.C., 2008, Upper Cretaceous molluscan record along a transect from Virden, New Mexico, to Del Rio, Texas. New Mexico Geology, v. 30, pp. 75-92.

Cooper, D.A., Cooper, R.W., Stevens, J.B., Stevens, M.S., Cobban, W.A., and Walaszczyk, I., 2017, The Boquillas Formation of the Big Bend National Park, Texas, USA, a reference Cenomanian through Santonian (Upper Cretaceous) carbonate succession at the southern end of the Western Interior Seaway. Acta Geologica Polonica, v. 67, pp. 547-565.

Cooper, R.A. (Ed.), 2004, The New Zealand geological timescale. Institute of Geological and Nuclear Sciences monograph, v. 22, pp. 1-284.

Coquand, H., 1857, Position des Ostrea columba et biauriculata dans le groupe de la craie inférieure. Bulletin de la Sociét Géologique de France, v. 14, pp. 745-766.

Coquand, H., 1859, Synopsis des animaux et des végétaux fossiles observés dans la formation crétac du sud-ouest de la France. Bulletin de la Sociét Géologique de France, (2), v. 16, pp. 945-1023.

Costa, L., and Davey, R.J., 1992, Dinoflagellate cysts of the Cretaceous System. In: Powell, A.J., (Ed.), A Stratigraphic Index of Dinoflagellate Cysts, Chapman and Hall, London, pp. 99-153.

Crame, J.A., 1981, Upper Cretaceous inoceramids (Bivalvia) from the James Ross Island Group and their stratigraphical significance. Bulletin of the British Antarctic Survey, v. 53, pp. 29-56.

Crampton, J.S., 1996, Inoceramid bivalves from the Late Cretaceous of New Zealand. Institute of Geological and Nuclear Sciences Mono- graph, v. 14, pp. i-iv, 1-188.

Crampton, J.S., 2004, Shell composition, cryptic costae, complex composite molds and taphonomic chicanery in Mytiloides (Inoceramidae, Bivalvia). Journal of Paleontology, v. 78, pp. 1187-1191.

Crampton, J.S., and Schiøler, P., 2019, Measured section through the boundary stratotype sections of the Arowhanan, Mangaotanean and Teratan stages (Late Cretaceous) in Mangaotane Stream, Raukumara Peninsula, New Zealand. GNS Science Report 2019/32.

Crampton, J., Raine, I., Strong, P., and Wilson, G., 2001, Integrated biostratigraphy of the Raukumara Series (Cenomanian-Coniacian) at Mangaotane Stream, Raukumara Peninsula, New Zealand. New Zealand Journal of Geology and Geophysics, v. 44, pp. 365-389.

Crampton, J.S., Hollis, C.J., Raine, J.I., LRoncaglia, L., Schiøler, P., Strong, C.P., and Wilson, G.J., 2004a, Cretaceous (Taitai, Clarence, Raukumara and Mata Series). In: Cooper, R.A. (Ed.), The New Zealand Geological Timescale, Institute of Geological and Nuclear Sciences, Lower Hutt, pp. 102-122

Crampton, J.S., Tulloch, A.J., Wilson, G.J., Ramezani, J., and Speden, I.G., 2004b, Definition, age, and correlation of the Clarence Series stages in New Zealand (late Early to early Late Cretaceous). New Zealand Journal of Geology and Geophysics, v. 47, pp. 1-19.

Deconinck, J.-F., Amédro, F., Baudin, F., Godet, A., Pellenard, P., Robaszynski, F., and Zimmerlin, I., 2005, Late Cretaceous palaeoenvironments expressed by the clay mineralogy of Cenomanian-Campanian chalks from the east of the Paris Basin. Cretaceous Research, v. 26, pp. 171-179.

Davey, R.J, and Verdier, J.P., 1976, A review of certain non-tabulate Cretaceous hystrichospherid dinocysts. Review of Palaeobotany and Palynology, v. 22, pp. 307-335.

Diebold, F., 2012, Systematics, biostratigraphy and biogeography of the ammonoid family Collignoniceratidae across the Turonian-Coniacian (Cretaceous) boundary in the West European and Indo-Malgach provinces. Chapter 2. Ruprecht-Karls-Universität; Heidelberg. [Ph.D. thesis].

Diebold, F., Bengtson, P., Lees, J., and Walaszczyk, I., 2010. Ammonite, inoceramid and nannofossil biostratigraphy across the Turonian-Coniacian boundary in the Aquitaine and Vocontian Basins (France) and Diego Basin (Madagascar). 8th International Symposium Cephalopods - Present and Past, Dijon, France, August 30th to September 3rd, 2010, Abstract Volume, p. 35.

Dochev, D., and Granchovski, G., 2017, Inoceramid bivalves and calcareous nannofossils from the Coniacian of the Western Srednogorie Unit (Western Bulgaria). Geologica Balcanica, v. 46, pp. 87-96.

Dubicka, Z., and Peryt, D., 2014, Classification and evolutionary interpretation of the late Turonian-early Campanian Gavelinella and Stensioeina (Gavelinellidae, benthic foraminifera) from western Ukraine. Journal of Foraminiferal Research, v. 44, pp. 151-176.

Edwards, P.G., 1981, The foraminiferid genus Gavelinella in the Senonian of north-west Europe. Palaeontology, v. 24, pp. 391-416.

Ernst, G., and Wood, C.J., 1995, Die tiefere Oberkreide des subherzynen Niedersachsens. Terra Nostra, v. 5/95, pp. 41-84.

Eynatten, H. von, Voigt, T., Meier, A., Franzke, H.-J., and Gaupp, R., 2007, Provenance of Cretaceous clastics in the Subhercynian Basin: constraints to exhumation of the Harz Mountains and timing of inversion tectonics in Central Europe. International Journal of Earth Sciences, v. 97, pp. 1315-1330.

Gale, A.S., 2019, Correlation, age and significance of Turonian Chalk hardgrounds in southern England and northern France: The roles of tectonics, eustasy, erosion and condensation. Cretaceous Research, v. 103, 104164, doi.org/10.1016/j.cretres.2019.06.010

Gale, A.S., Kennedy, W.J., and Walaszczyk, I., 2019, Upper Albian, Cenomanian and Lower Turonian stratigraphy, ammonite and inoceramid bivalve faunas from the Cauvery Basin, Tamil Nadu, South India. Acta Geologica Polonica, v. 69, pp. 161-338.

Gale, A.S., Mutterlose, J., Batenburg, S., Gradstein, F.M., Agterberg, F.P., Ogg, J.G., and Petrizzo, M.R., 2020, Chapter 27, The Cretaceous 
Period. In: Gradstein, F.M. et al., (Eds.), Geologic Time Scale, Elsevier, pp. 1023-1086.

Gebhardt, H., 2001, Inoceramids, Didymotis and ammonites from the Nkalagu Formation type locality (late Turonian to Coniacian, southern Nigeria): biostratigraphy and palaeoecologic implications. Neues Jahrbuch für Geologie und Palaeontologie, Monatshefte 2001 (4), pp. 193-212.

Georgescu, M.D., 2007, A new planktonic foraminiferal genus from the Upper Cretaceous (Turonian). Micropaleontology, v. 53, pp. 212-220.

Georgescu, M.D., 2017, Upper Cretaceous planktic foraminiferal biostratigraphy. Studia UBB Geologia, v. 61, pp. 5-20.

Georgescu, M.D., Quinney, A.E., and Anderson, K.D., 2011, New data on the taxonomy, evolution and biostratigraphical significance of the Turonian-Coniacian (Late Cretaceous) planktic foraminifer Huberella Georgescu 2007. Micropaleontology, v. 57, pp. 247-254.

Gradstein, F.M., Agterberg, F.P., Ogg, J.G., Hardenbol, J., Veen, P. van, Thierry, J., and Huang, Z., 1994, A Mesozoic time scale. Journal of Geophysical Research: Solid Earth, v. 99, pp. 24051-24074.

Hancock, J.M., 1991, Ammonite scales for the Cretaceous System. Cretaceous Research, v. 12, pp. 259-291.

Hancock, J.M., and Walaszczyk, I., 2004, Mid-Turonian to Coniacian changes of sea level around Dallas, Texas. Cretaceous Research, v. 25, pp. 459-471.

Haq, B.U., 2014, Cretaceous eustasy revisited. Global and Planetary Change, v. 113, pp. 44-58.

Haynes, S.J., Huber, B.T., and Macleod, K.G., 2015, Evolution and phylogeny of mid-Cretaceous (Albian-Coniacian) biserial planktic foraminifera. Journal of Foraminiferal Research, v. 45, pp. 42-81.

Hallam, A., Hancock, J.M., LaBrecque, J.L., Lowrie, W., and Channell, J.E.T., 1985, Jurassic to Paleogene: Part I Jurassic and Cretaceous geochronology and Jurassic to Paleogene magnetostratigraphy. Geological Society, London, Memoirs, v. 10, pp. 118-140.

Hardenbol, J., Thierry, J., Farley, M.B., Jacquin, T., and Vail, P.R., 1998, Mesozoic and Cenozoic sequence chronostratigraphic framework of European Basins. In: de Graciansky, P.-C., et al. (Eds.), Mesozoic and Cenozoic Sequence Stratigraphy of European Basins. SEPM Special Publication, v. 60, pp. 3-13.

Hasegawa, T., Crampton, J.S., Schiøler, P., Field, B., Fukushi, K., and Kakizaki, Y., 2013, Carbon isotope stratigraphy and depositional oxia through Cenomanian/Turonian boundary sequences (Upper Cretaceous) in New Zealand. Cretaceous Research, v. 40, pp. 61-80.

Hayakawa, T., and Hirano, H., 2013, A revised inoceramid biozonation for the Upper Cretaceous based on high-resolution carbon isotope stratigraphy in northwestern Hokkaido, Japan. Acta Geologica Polonica, v. 63, pp. 239-263.

Helby, R., Morgan, R., and Partridge, A.D., 1987, A palynological zonation of the Australian Mesozoic. Memoir of the Association of Australasian Palaeontologists, v. 4, pp. 1-94.

Hiss, M., and Schönfeld, J., 2000, Einführung. In: Stratigraphische Kommission Deutschlands (Ed.), Stratigraphie von Deutschland, III. Die Kreide der Bundesrepublik Deutschland. Courier Forschungsinstitut Senckenberg, v. 226, pp. 3-6.

Hiss, M., Niebuhr, B., and Teipel, U., 2018, Die Kreide in der Stratigraphischen Tabelle von Deutschland 2016. Zeitschrift der Deutschen Gesellschaft für Geowissenschaften, v. 169, pp. 247-266.

Hornacsek, M., and Ifrim, C., 2017, Litho-, Bio-, Kohlenstoffisotopenstratigraphie und Sedimentologie der Erwitte-Formation (Unterconiacium, Kreide) südlich von Paderborn. Geologie und Paläontologie in Westfalen, v. 89, pp. 21-50.

Hradeck, L., 1996, Gavelinella Brotzen, 1942 and Lingulogavelinella Malapris, 1969 (Foraminifera) from the Bohemian Cretaceous basin. Sbornik Geologickỳch Vêd, Paleontologie, v. 33, pp. 79-96.

Huber, B.T., Petrizzo, M.R., Young, J.R., Falzoni, F., Gilardoni, S.E., Bown, P.R., and Wade, B.S. (2016), Pforams@microtax. Micropaleontology, v. 62 , pp. $429-438$.

Huber, B.T., Petrizzo, M.R., Watkins, D.K., Haynes, S.J., and MacLeod,
K.G., 2017, Correlation of Turonian continental margin and deep-sea sequences in the subtropical Indian Ocean sediments by integrated planktonic foraminiferal and calcareous nannofossil biostratigraphy. Newsletters on Stratigraphy, v. 50, pp. 141-185.

Ifrim, C., Wiese, F., and Stinnesbeck, W., 2014, Inoceramids and biozonation across the Turonian-Coniacian boundary (Upper Cretaceous) at El Rosario, Coahuila, northeastern Mexico Newsletters on Stratigraphy, v. 47, pp. 211-246

Ifrim, C., Stinnesbeck, W., Porras Muzquiz, H., Padilla Gutierrez, J.M., and González González, A.H., 2019, Ammonoids and their biozonation across the Turonian-Coniacian (Late Cretaceous) boudary in northern Coahuila, Mexico. Cretaceous Research, v. 102, pp. 170-195.

Jarvis, I., Gale, A.S., Jenkyns, H.C., and Pearce, M.A., 2006, Secular variation in Late Cretaceous carbon isotopes and sea-level change: evidence from a new $\delta^{13} \mathrm{C}$ carbonate reference curve for the CenomanianCampanian (99.6 - 70.6 Ma). Geological Magazine, v. 143, pp. 561-608

Jarvis, I., Trabucho-Alexandre, J., Gröcke, D.R., Uličný, D., and Laurin, J., 2015, Intercontinental correlation of organic carbon and carbonate stable isotope records: evidence of climate and sea-level change during the Turonian (Cretaceous). The Depositional Record, v. 1, pp. 53-90.

Jarvis, I., Pearce, M., Püttmann, T., Voigt, S., and Walaszczyk, I., 2021, Palynology and calcareous nannofossil biostratigraphy of the TuronianConiacian boundary: The proposed boundary stratotype at SalzgitterSalder, Germany and its correlation in NW Europe. Cretaceous Research, v. 123, 104782, doi.org/10.1016/j.cretres.2021.104782

Jenkyns, H.C., Gale, A.S., and Corfield, R.M., 1996, Carbon- and oxygenisotope stratigraphy of the English Chalk and Italian Scaglia and its palaeoclimatic significance. Geological Magazine, v. 131, pp. 1-34.

Jones, B., and Manning, D.A.C., 1994, Comparison of geochemical indices used for the interpretation of paleoredox conditions in ancient mudstones. Chemical Geology, v. 111, pp. 111-129.

Joo, Y.J., and Sageman, B.B., 2014, Cenomanian to Campanian carbon isotope chemostratigraphy from the Western Interior Basin, U.S.A. Journal of Sedimentary Research, v. 84, pp. 529-542.

Jurkowska, A., Świerczewska-Gładysz, E., Bąk, M., and Kowalik, S., 2019, The role of biogenic silica in the formation of Upper Cretaceous pelagic carbonates and its palaeoecological implications. Cretaceous Research, v. 93, pp. 170-187.

Kaplan, U., and Kenendy, W.J., 1994, Ammoniten des Westfälischen Coniac. Geologie und Paläontologie Westfalen, v. 31, pp. 1-155.

Kaplan, U., and Kennedy, W.J., 1996, Upper Turonian and Coniacian ammonite stratigraphy of Westphalia, NW-Germany. Acta Geologica Polonica, v. 46, pp. 305-352.

Kauffman, E.G., 1973, Cretaceous Bivalvia. In: A. Hallam (Ed.), Atlas of Palaeobiogeography, Elsevier Scientific Publishing Company, Amsterdam - London - New York, pp. 353-383.

Kauffman, E.G., and Bengston, P., 1985, Mid-Cretaceous inoceramids from Sergipe, Brazil; a progress report. Cretaceous Research, v. 6, pp. 311315.

Kauffman, E.G. (compiler), Kennedy, W.J., and Wood, C.J., 1996, The Coniacian stage and substage boundaries. Bulletin de l'Institut Royal des Sciences Naturelles de Belgique, v. 66 - Supplément, pp. 81-94.

Kennedy, W.J., 1978, The middle Cretaceous of Zululand and Natal, eastern South Africa. In: Événements de la party doyenne du Crétac. Uppsala 1975 - Nice 1976. Annales du Museum d'Histoire Naturelle de Nice, v. 4, pp. 1-29.

Kennedy, W.J., 1983, Ammonite faunas of the Coniacian, Santonian and Campanian stages in the Aquitaine Basin. Géologie Méditerranéenne, v. 10, pp. 103-113.

Kennedy, W.J., 1984a, Systematic palaeontology and stratigraphic distribution of the ammonite faunas of the French Coniacian. Special Papers in Palaeontology, v. 31, pp. 1-160.

Kennedy, W.J., 1984b, Ammonite faunas and the 'standard zones' of the Cenomanian to Maastrichtian Stages in their type areas, with some proposals for the definition of the stage boundaries by ammonites. Bulletin 
of the Geological Society of Denmark, v. 33, pp. 147-161

Kennedy. W.J., 2020, A monograph of the Ammonoidea of the Upper Chalk. Part 2, Monograph of the Palaeontographical Society, London, Publication No. 656, part of Volume 174 for 2020, pp. 113-222.

Kennedy, W.J., and Cobban, W.A., 1991, Coniacian ammonite faunas from the United States Western Interior. Special Papers in Palaeontology, v. 45, pp. 1-96.

Kennedy, W.J., and Kaplan, U., 2019, Ammoniten aus dem Turonium des Münsterländer Kreidebeckens, Geologie und Paläontologie in Westfalen, v. 91, pp. 1-223.

Kennedy, W.J., and Klinger, H.C., 1975, Cretaceous faunas from Zululand and Natal, South Africa. Introduction, stratigraphy. Bulletin of the British Museum (Natural History), Geology, v. 25, pp. 263-315.

Kennedy, W.J., and Klinger, H.C. 2013, Scaphitid ammonites from the Upper Cretaceous of KwaZulu-Natal and Eastern Cape Province, South Africa. Acta Geologica Polonica, v. 63, pp. 527-543.

Kennedy, W.J., and Walaszczyk, I., 2004. Forresteria (Harleites) petrocoriensis (Coquand, 1859) from the Upper Turonian Mytiloide scupini Zone of Słupia Nadbrzeżna, Poland. Acta Geologica Polonica, v. 54, pp. 55-59.

Kennedy, W.J., Wright, C.W., and Hancock, J.M., 1983, Ammonite zonation and correlation of the uppermost Cenomanian and Turonian Chalk sequences of southern England and the type areas of Sarthe and Touraine in France. Mémoires, Museum National d'Histoire Naturelle Paris, Sér. C, v. 49, pp. 175-181.

Kennedy, W.J., Bilotte, M., and Melchior, P., 1995, Ammonite faunas, biostratigraphy and sequence stratigraphy of the Coniacian-Santonian of the Corbières (N.E. Pyrénées). Bulletin des Centres de Recherche Exploration-Production Elf-Aquitaine, v. 19, pp. 377-499.

Kennedy, W.J., Cobban, W.A. and Landman, N.L., 2001, A revision of the Turonian members of the ammonite subfamily Collignoniceratinae from the United States Western Interior and Gulf Coast, Bulletin of the American Museum of Natural History, v. 267, pp. 1-148.

Kennedy, W.J., Phansalkar, V.G., and Walaszczyk, I., 2003, Prionocyclus germari (Reuss, 1845), a Late Turonian marker fossil from the Bagh Beds of central India, Creaceous Research, v. 24, pp. 433-438.

Kent, D.V., and Gradstein, F.M., 1985, A Cretaceous and Jurassic geochronology. Bulletin of the Geological Society of America, v. 96, pp. 1419-1427.

Koch, W., 1977, Stratigraphie der Oberkreide in Nordwestdeutschland (Pompeckjsche Scholle). Teil 2. Biostratigraphie in der Oberkreide und Taxonomie von Foraminiferen: Geologisches Jahrbuch, v. A38, pp. 11-123.

Kopaevich, L.F., and Walaszczyk, I., 1990, An integrated inoceramid-foraminiferal biostratigraphy of the Turonian and Coniacian strata in south-western Crimea, Soviet Union. Acta Geologica Polonica, v. 40, pp. 83-96.

Kozłowski, W., and Sobień, K., 2012, Mid-Ludfordian coeval carbon isotope, natural gamma ray and magnetic susceptibility excursions in the Mielnik IG-1 borehole (Eastern Poland) - Dustiness as a possible link between global climate and the Silurian carbon isotope record. Palaeogeography, Palaeoclimatology, Palaeoecology, v. 339-341, pp. 74-97.

Küchler, T., 1998, Upper Cretaceous of the Barranca (Navarra, northern Spain); integrated litho-, bio- and event stratigraphy. Part I. Cenomanian through Santonian. Acta Geologica Polonica, v. 48, pp. 157236

Kuwabara, S., Takashima, R., Orihashi, Y., Nishi, H., Satoh, T., and Hayashi, K., 2019, Preliminary tephrochronological study of the Yezo Group (uppermost Albian-basal Campanian) in north Japan. Cretaceous Research, v. 103, pp. 104-158.

Laskar, J., 2020, Chapter 4 - Astrochronology. In: Gradstein, F.M. et al. (Eds.), Geologic Time Scale, Elsevier, pp. 139-158.

Laskar, J., Fienga, A., Gastineau, M., and Manche, H., 2011, La2010: a new orbital solution for the long-term motion of the Earth. Astronomy \& Astrophysics, v. 532, A89, doi:10.1051/0004-6361/201116836
Laurin, J., Čech, S., Uličný, D., Štaffen, Z., and Svobodová, M., 2014, Astrochronology of the Late Turonian: implications for the behavior of the carbon cycle at the demise of peak greenhouse. Earth and Planetary Science Letters, v. 394, pp. 254-269.

Lees, J.A., 2008, The calcareous nannofossil record across the Late Cretaceous Turonian/Coniacian boundary, including new data from Hermany, Poland, the Czech Republic and England. Cretaceous Research, v. 29, pp. 40-64.

Li, Y.-H., 2000, A Compendium of Geochemistry: From Solar Nebula to the Human Brain. Princeton University Press, Princeton, New Jersey, $440 \mathrm{p}$.

Locklair, R.E., and Sageman, B.B., 2008, Cyclostratigraphy of the Upper Cretaceous Niobrara Formation, Western Interior, U.S.A.: A Coniacian-Santonian orbital timescale. Earth and Planetary Science Letters, v. 269, pp. 540-553.

Marcinowski, R., and Radwański, A., 1983, The mid-Cretaceous transgression onto the Central Polish Uplands (marginal part of the Central European Basin). Zitteliana, v. 10, pp. 65-95.

Marcinowski, R., Walaszczyk, I., and Olszewska-Nejbert, D., 1996, Stratigraphy and regional development of the mid-Cretaceous (Upper Albian through Coniacian) of the Mangyshlak Mountains, Western Kazakhstan. Acta Geologica Polonica, v. 46, pp. 1-60.

Marshall, N.G., 1984, Late Cretaceous dinoflagellates from the Perth Basin, Western Australia. Unpublished PhD Thesis, University of Western Australia, Perth, 297 p.

Matsumoto, T., 1984, The so-called Turonian-Coniacian boundary in Japan. Bulletin of the Geological Society of Denmark, v. 33, pp. 171181.

Matsumoto, T., and Noda, M., 1985, A note on an inoceramid species (Bivalvia) from the Lower Coniacian (Cretaceous) of Hokkaido. Transactions and Proceedings of the Palaeontological Society of Japan, N.S., v. 140, pp. 263-273.

McArthur, J.M., Crame, J.A, and Thirlwall, M.F., 2000, Definition of Late Cretaceous stage boundaries in Antarctica using strontium isotope stratigraphy. Journal of Geology, v. 108, pp. 623-640.

McMinn, A., 1988, Outline of a Late Cretaceous dinoflagellate zonation of Australia. Alcheringa, v. 12, pp. 137-56.

Merewether, E.A., and Cobban, W.A., 1986, Biostratigraphic units and tectonism in the mid-Cretaceous foreland of Wyoming, Colorado, and adjoining areas: Part III. Middle Rocky Mountains. In: Peterson, J.A. (Ed.), Paleotectonics and Sedimentation: American Association of Petroleum Geologists Memoir, v. 41. AAPG Special Volumes, pp. 443-468.

Morgan, R., 1980, Palynostratigraphy of the Australian Early and middle Cretaceous. Memoirs of the Geological Survey of New South Wales. Palaeontology, v. 18, pp. 1-153.

Nederbragt, A.J., 1990, Biostratigraphy and paleoceanographic potential of the Cretaceous planktic foraminifera Heterohelicidae, Vrije University, Amsterdam, 204 p.

Niebuhr, B., Hiss, M., Kaplan, U., Tröger, K.-A., Voigt, S., Voigt, T., Wiese, F., and Wilmsen, M., 2007, Lithostratigraphie der norddeutschen Oberkreide. Schriftenreihe der Deutschen Gesellschaft für Geowissenschaften, v. 55, pp. 1-136.

Noda, M., and Matsumoto, T., 1998, Palaeontology and stratigraphy of the inoceramid species from the mid-Turonian through upper Middle Coniacian in Japan. Acta Geologica Polonica, v. 48, pp. 435-482.

Obradovich, J., 1993, A Cretaceous time scale. In: Caldwell, W.G.E., and Kauffman, E.G. (Eds.), Evolution of the Western Interior Basin. Geological Society of Canada Special Paper, v. 39, pp. 379-396.

Ogg, J.G., Agtenberg, F.P., and Gradstein, F.M., 2004, The Cretaceous Period. In: F.M. Gradstein, J. Ogg and A. Smith (Eds.), A Geologic Time Scale 2004, Cambridge University Press, Cambridge, pp. 344 383.

Ogg, J.G., Hinnov, L.A., and Huang, C., 2012, Chapter 27, Cretaceous. In: The Geologic Time Scale, Elsevier, Boston, pp. 793-853.

Ogg, J.G., Ogg, G.M., and Gradstein, F.M., 2016, Cretaceous. In: Ogg, 
J.G., Ogg, G.M., and Gradstein, F.M. (Eds.), A Concise Geologic Time Scale, Elsevier, pp. 167-186.

Olde, K., Jarvis, I., Pearce, M.A., Uličný, D., Tocher, B.A., TrabuchoAlexandre, J., and Gröcke, D., 2015a, A revised northern European Turonian (Upper Cretaceous) dinoflagellate cyst biostratigraphy: integrating palynology and carbon isotope events. Review of Palaeobotany and Palynology, v. 213, pp. 1-16.

Olde, K., Jarvis, I., Uličný, D., Pearce, M.A., Trabucho-Alexandre, J., Čech, S., Gröcke, D.R., Laurin, J., Švábenická, L., and Tocher, B.A., 2015b, Geochemical and palynological sea-level proxies in hemipelagic sediments: a critical assessment from the Upper Cretaceous of the Czech Republic. Palaeogeography, Palaeoclimatology, Palaeoecology, v. 435, pp. 222-243.

Olde, K., Jarvis, I., Pearce, M., Walaszczyk, I., and Tocher, B., 2016, Organic-walled dinoflagellate cyst records from a prospective Turonian-Coniacian (Upper Cretaceous) GSSP, Słupia Nadbrzeżna, Poland. Cretaceous Research, v. 65, pp. 17-24.

Orbginy, A.d', 1842-1843, Paléontologie française: Terrains crétacés. 2. Gastéropodes, Paris, Masson, 1-224 (1842); 225-456 (1843).

Parkinson, D.N., 1996, Gamma-ray spectrometry as a tool for stratigraphical interpretation: examples from the western European Lower Jurassic. In: Hesselbo, S.P., and Parkinson, D.N. (Eds.), Sequence Stratigraphy in British Geology, Geological Society Special Publication, v. 103, pp. 231-255.

Pauliuc, S., 1968, Studiul geologic al Persanilor centrali cu privire speciala la Cretacicul superior. Studii Tehnice si Economice, Serie J, Stratigrafie, v. 4, pp. 1-133.

Pearce, M.A., Jarvis, I., Swan, A.R.H., Murphy, A.M., Tocher, B.A., and Edmunds, W.M., 2003, Integrating palynological and geochemical data in a new approach to palaeoecological studies: Upper Cretaceous of the Banterwick Barn Chalk borehole, Berkshire, UK. Marine Micropaleontology, v. 47, pp. 271-306.

Pearce, M.A., Jarvis, I., Ball, P.J., and Laurin, J., 2020, Palynology of the Cenomanian to lowermost Campanian (Upper Cretaceous) Chalk of the Trunch Borehole (Norfolk, UK) and a new dinoflagellate cyst bioevent stratigraphy for NW Europe. Review of Palaeobotany and Palynology, v. 278, pp. 104-188.

Petrizzo, M.R., Jiménez Berrocoso, A., Falzoni, F., Huber, B.T., and Macleod, K.G., 2017, The Coniacian-Santonian sedimentary record in southern Tanzania (Ruvuma Basin, East Africa): planktonic foraminiferal evolutionary, geochemical and palaeoceanographic patterns. Sedimentology, v. 64 , pp. 252-285.

Petrizzo, M.R., Huber, B.T., Falzoni, F., and MacLeod, K.G., 2020, Changes in biogeographic distribution patterns of southern mid- to high latitude planktonic foraminifera during the Late Cretaceous hot to cool greenhouse climate transition. Cretaceous Research, v. 115, 104547, doi.org/10.1016/j.cretres.2020.104547

Pożaryski, W., 1938, Senonstratigraphie im Durchbruch der Weichselzwischen Rachw und Puławy in Mittelpolen. Biuletyn Państwowego Instytutu Geologicznego, v. 6, pp. 1-94. [In Polish, with extended German summary].

Poyarkova, Z.N. (Ed.), 1987, Reference section of Cretaceous deposits in Sakhalin (Naiba section). Transactions of the Academy of Sciences of USSR, v. 16, pp. 1-197. [In Russian, with English abstract].

Premoli Silva, I., and Sliter, W.V., 1995, Cretaceous planktonic foraminiferal biostratigraphy and evolutionary trends from the Bottaccione section, Gubbio, Italy. Paleontographia Italica, v. 82, pp. 1-89.

Prince, I.M., Jarvis, I., Pearce, M.A., and Tocher, B.A., 2008, Dinoflagellate cyst biostratigraphy of the Coniacian-Santonian (Upper Cretaceous): New data from the English Chalk. Review of Palaeobotany and Palynology, v. 150, pp. 59-96.

Raine, J.I., 2014, New Zealand Cretaceous miospore biostratigraphy and non-marine correlations. Advantage NZ: Geotechnical Petroleum Forum 2014, 1-3 April 2014, Wellington, New Zealand; Forum Programme, technical posters, A6.
Raine, J.I., Beu, A.G, Boyes, A.F., Campbell, H.J., Cooper, R.A, Crampton, J.S, Crundwell, M.P., Hollis, C.J., Morgans, H.E.G., and Mortimer, N., 2015, New Zealand geological timescale NZGT 2015/1. New Zealand Journal of Geology and Geophysics, v. 58, pp. 398-403.

Rasemann, G., 1984, Stratigraphie der Salzgitterer Struktur zwischen Osterlinde und Salder unter besonderer Bercksichtigung der Oberkreide (Turon-Coniac). Freie Universitåt Berlin. 197 pp. [Unpubl. Diplom thesis].

Riding, J.B., and Crame, J.A., 2002, Aptian to Coniacian (Early-Late Cretaceous) palynostratigraphy of the Gustav Group, James Ross Basin, Antarctica. Cretaceous Research, v. 23, pp. 739-760.

Riding, J.B., Keating, J.M., Snape, M.G, Newham, S., D., and Pirrie, D., 1992, Preliminary Jurassic and Cretaceous dinoflagellate cyst stratigraphy of the James Ross Island area, Antarctic Peninsula. Newsletters on Stratigraphy, v. 26, pp. 19-39.

Robaszynski, F., and Caron, M., 1979, Atlas of mid Cretaceous planktonic foraminifera (Boreal Sea and Tethys). Cahiers de Micropaléontologie, v. 1-2, pp. 1-366.

Robaszynski, F., and Caron, M., 1995, Foraminifères planctoniques du Crétacé: commentaire de la zonation Europe-Mediterranée. Bulletin de la Société Géologique de France, v. 166, pp. 681-692.

Robaszynski, F., Caron, M., Dupuis, C., Amédro, F., Gonzales Donoso, J.M., Linares, D., Hardenbol, J., Gartner, S., Calandra, F., and Deloffre, R., 1990, A tentative integrated stratigraphy in the Turonian of Central Tunisia: Formations, zones and sequential stratigraphy in the Kalaat Senan area. Bulletin des Centres de Recherches ExplorationProduction Elf-Aquitaine, v. 14, pp. 213-384.

Roncaglia, L., Field, B.D., Raine, J.I., Schiøler, P., and Wilson, G.J., 1999, Dinoflagellate biostratigraphy of Piripauan-Haumurian (Upper Cretaceous) sections from northeast South Island, New Zealand. Cretaceous Research, v. 20, pp. 271-314.

Ruffell, A., and Worden, R., 2000, Palaeoclimate analysis using spectral gamma-ray data from the Aptian (Cretaceous) of southern England and southern France. Palaeogeography, Palaeoclimatology, Palaeoecology, v. 155, pp. 265-283.

Sageman, B.B., Singer, B.S., Meyers, S.R., Siewert, S.E., Walaszczyk, I., Condon, D.J., Jicha, B.R., Obradovich, J.D., and Sawyer, D.A., 2014, Integrating ${ }^{40} \mathrm{Ar} /{ }^{39} \mathrm{Ar}$, U-Pb, and astronomical clocks in the Cretaceous Niobrara Formation, Western Interior Basin, USA. Bulletin of the Geological Society of America, v. 126, pp. 956-973.

Scheck-Wenderoth, M., Krzywiec, P., Zühlke, R., Maystrenko, Y., and Froitsheim, N., 2008, Permian to Cretaceous tectonics. In: McCann, T. (ed.), The Geology of Central Europe, Volume 2: Mesozoic and Cenozoic, The Geological Society, London, London, pp. 999-1030.

Schiøler, P., and Crampton, J.S., 2014, Dinoflagellate biostratigraphy of the Arowhanan Stage (upper Cenomanian - lower Turonian) in the East Coast Basin, New Zealand. Cretaceous Research, v. 48, pp. 205-224.

Schiøler, P., and Wilson, G.J., 1998, Dinoflagellate biostratigraphy of the middle Coniacian - lower Campanian (Upper Cretaceous) in south Marlborough, New Zealand. Micropaleontology, v. 44, pp. 313-349.

Schnyder, J., Ruffel, A., Deconinck, J.-F., and Baudin, F., 2006, Conjunctive use of spectral gamma-ray logs and clay mineralogy in defining late Jurassic - early Cretaceous palaeoclimate change (Dorset, U.K.). Palaeogeography, Palaeoclimatology, Palaeoecology, v. 229, pp. 303-320.

Scotese, C.R., 2001, PALEOMAP project. http://www.scotese.com/earth.htm.

Seeling, J., and Bengtson, P., 2003, The Late Cretaceous bivalve Didymotis Gerhardt, 1897 from Sergipe, Brazil. Paläontologische Zeitschrift, v. 77 , pp. $153-160$.

Séronie-Vivien, M., 1972, Contribution à l'étude du Sénonien en Aquitaine septentrionale. Les stratotypes: Coniacien, Santonien et Campanien. Editions du Centre National de la Recherche Scientifique, Paris, pp. 1-195.

Séronie-Vivien, M., 1980, Coniacien. Mémoires du Bureau de Recherches Géologiques et Minières, v. 109, pp. 150-155.

Sigal, J., 1955, Notes micropaléontologiques nord-africaines. 1. Du Céno- 
manien au Santonien: zones et limites en faciès pélagique. Compte Rendu Sommaire des Séances de la Société Géologique de France, v. 7-8, pp. 157-160.

Sikora, P.J., Howe, R.W., Gale, A.S., and Stein, J.A., 2004, Chronostratigraphy of proposed Turonian-Coniacian (Upper Cretaceous) stage boundary stratotypes: Salzgitter-Salder, Germany, and Wagon Mound, New Mexico, USA. In: A.B. Beaudoin, and M.J. Head (Eds), The Palynology and Micropalaeontology of Boundaries. Geological Society, London, Special Publications, v. 230, pp. 207-242.

Stinnesbeck, W., Ifrim, C., Schmidt, H., Rindfleisch, A., Buchy, M.-C., Frey, E., González González, A.H., Vega-Vera, F.J., Porras-Muzquiz, H., Cavin, L., Keller, G., and Smith, K.T., 2005, A new lithographic limestone deposit in the Upper Cretaceous Austin Group at El Rosario, county of Muzquiz, Coahuila, northeastern Mexico. Revista Mexicana de Ciencias Geológicas, v. 22, pp. 401-418.

Švábenická, L. 2009, Svrchní turon na základě studia vápnitých nanofosilií v oblasti Českého ráje, česká křídová pánev. Sborník Muzea Českého ráje, v. 4, pp. 133-141. [In Czech with English abstract].

Švábenická, L., 2010, Late Turonian and Turonian-Coniacian boundary according to study of calcareous nannofossils in the Bohemian Cretaceous Basin, Jizera development. Zprávy o geologických Výzkumech v Roce 2009, pp. 58-64. [In Czech, with English abstract].

Svobodová, M., 2011, Late Turonian and Coniacian according to study of palynomorphs in the borehole V 800 Střeleč (Jizera Development, Bohemian Cretaceous Basin). Zprávy o geologických Výzkumech v Roce 2010, pp. 120-127. [In Czech, with English abstract].

Takashima, R., Nishi, H., Yamanaka, T., Hayashi, K., Waseda, A., Obuse, A., Tomosugi, T., Deguchi, N., and Mochizuki, S., 2010, High-resolution terrestrial carbon isotope and planktic foraminiferal records of the Upper Cenomanian to the Lower Campanian in the Northwest Pacific. Earth and Planetary Science Letters, v. 289, pp. 570-582.

Takashima, R., Nishi, H., Yamanaka, T., Orihashi, Y., Tsujino, Y., Quidelleur, X., Hayashi, K., Sawada, K., Nakamura, H., and Ando, T., 2019, Establishment of Upper Cretaceous bio- and carbon isotope stratigraphy in the northwest Pacific Ocean and radiometric ages around the Albian/ Cenomanian, Coniacian/Santonian and Santonian/Campanian boundaries. Newsletters on Stratigraphy, v. 52, pp. 341-376.

Toshimitsu, S., Matsumoto, T., Noda, M., Nishida, T., and Maiya, S., 1995, Towards an integrated of mega-, micro- and magneto-stratigraphy of the Upper Cretaceous in Japan. Journal of the Geological Society of Japan, v. 101, pp. 19-29.

Toshimitsu, S., Hasegawa, T., and Tsuchiya, K., 2007, Coniacian-Santonian stratigraphy in Japan: a review. Cretaceous Research, v. 28, pp. $128-131$.

Uličný, D., Laurin, J., and Čech, S., 2009, Controls on clastic sequence geometries in a shallow marine, transtensional basin: the Bohemian Cretaceous Basin, Czech Republic. Sedimentology, v. 56, pp. 10771114.

Uličný, D., Jarvis, I., Gröcke, D.R., Čech, S., Laurin, J., Olde, K., Trabucho-Alexandre, J., Švábenická, L., and Pedenychouk, N., 2014, A high-resolution carbon-isotope record of the Turonian stage correlated to a siliciclastic basin fill: implications for mid-Cretaceous sea-level change. Palaeogeography, Palaeoclimatology, Palaeoecology, v. 405, pp. 42-58.

Vasilenko, V.P., 1954, Anomalinids. Trudy, Vsesoyuznogo Neftyanogo Nauchno-Isledovatel'skogo Geologo-Razvedochnogo Instituta (VNIGRI), v. 80, pp. 1-282. [In Russian].

Vasilenko, V.P., 1961, Upper Cretaceous foraminifera from the Mangyshlak Peninsula. Trudy, Vsesoyuznogo Neftyanogo Nauchno-Issledovatel'skogo Geologo-Razvedochnogo Instituta (VNIGRI), v. 171, pp. 3390. [In Russian].

Vega, F.J., Nyborg, T., Rojas-Briceño, A., Patarroyo, P., Luque, J., PorrasMuzquiz, H., and Stinnesbeck, W., 2007, Upper Cretaceous Crustacea from Mexico and Columbia: similar faunas and environments during Turonian times. Revista Mexicana de Ciencias Geológicas, v. 24, pp.
$403-422$.

Vishnevskaya, V.S., Kopaevich, L.F., Beniamovskii, V.N., and Ovechkina, M.N., 2018, The correlation of the Upper Cretaceous zonal schemes of the eastern European platform based on foraminifera, radiolaria, and nannoplankton. Moscow University Geology Bulletin, v. 73, pp. 131-140.

Voigt, S., and Hilbrecht, H., 1997, Late Cretaceous carbon isotope stratigraphy in Europe: correlation and relations with sea level and sediment stability. Palaeogeography, Palaeoclimatology, Palaeoecology, v. 134, pp. 39-59.

Voigt, T., Wiese, F., von Eynatten, H., Franzke, H.-J., and Gaupp, R., 2006, Facies evolution of syntectonic Upper Cretaceous deposits in the Subhercynian Cretaceous Basin and adjoining areas (Germany). Zeitschrift der Deutschen Gessellschaft für Geowissenschaften, v. 157, pp. 203-244.

Voigt, S., Wagreich, M., Surlyk, F., Walaszczyk, I., Uličný, D., Čech, S., Voigt, T., Wiese, F., Wilmsen, M., Niebuhr, B., Reich, M., Funk, H., Michalík, J., Jagt, J.W.M., Felder, P.J., and Schulp, A.S., 2008, Cretaceous. In: McCann, T. (Ed.), Geology of Central Europe. Volume 2. Mesozoic and Cenozoic. The Geological Society, London, pp. 923 997.

Voigt, S., Püttmann, T., and Mutterlose, J., 2017, Reassessment of Salzgitter-Salder as potential stratotype for the Turonian-Coniacian boundary. 10th International Symposium on the Cretaceous, Vienna, August 21-26, 2017-Abstracts. Berichte der Geologischen Bundesanstalt, v. 120 , p. 271.

Voigt, S., Püttmann, T., Mutterlose, J., Bornemann, A., Jarvis, I., Pearce, M., and Walaszczyk, I., 2021, Reassessment of the Salzgitter-Salder section as a potential stratotype for the Turonian-Coniacian boundary: stable carbon isotopes and cyclostratigraphy constrained by calcareous nannofossils and palynology. Newsletters on Stratigraphy, v. 54, pp. 209-228. doi.org/10.1127/nos/2020/0615

Walaszczyk, I., 1992, Turonian through Santonian deposits of the Central Polish Uplands; their facies development, inoceramid paleontology and stratigraphy. Acta Geologica Polonica, v. 42, pp. 1-122.

Walaszczyk, I., 2000, Inoceramid bivalves at the Turonian/Coniacian boundary: biostratigraphy, events, and diversity trend. Acta Geologica Polonica, v. 50, pp. 421-430.

Walaszczyk, I., and Cobban, W.A., 1998, The Turonian-Coniacian boundary in the United States Western Interior. Acta Geologica Polonica, v. 48, pp. 495-507.

Walaszczyk, I., and Cobban, W.A., 2000, Inoceramid faunas and biostratigraphy of the Upper Turonian-Lower Coniacian of the Western Interior of the United States. Special Papers in Palaeontology, v. 64, pp. 1-118.

Walaszczyk, I., and Peryt, D., 1998, Inoceramid and foraminiferal biostratigraphy of the Turonian through Santonian deposits of the Middle Vistula Section, Central Poland. Zentralblatt für Geologie und Paläontologie, v. 11/12, pp. 1501-1513.

Walaszczyk, I., and Wood, C.J., 1998, Inoceramids and biostratigraphy at the Turonian/Coniacian boundary; based on the Salzgitter-Salder Quarry, Lower Saxony, Germany, and the Słupia Nadbrzeżna section, Central Poland. Acta Geologica Polonica, v. 48, pp. 395-434.

Walaszczyk, I., and Wood, C.J., 2008, Turonian-Coniacian boundary; definition, recognition and stratotype problems. Proceedings of the 33rd International Geological Congress, Oslo 2008, August 6-14, p. 3315.

Walaszczyk, I., Kopaevich, L.F., and Olferiev, A.G., 2004, Inoceramid/foraminiferal succession of the Turonian and Coniacian (Upper Cretaceous) of the Briansk region (Central European Russia). Acta Geologica Polonica, v. 54, pp. 569-581.

Walaszczyk, I., Marcinowski, R., Praszkier, T., Dembicz, K., and Bienkowska, M., 2004, Biogeographical and stratigraphical significance of the latest Turonian and Early Coniacian inoceramid/ammonite succession of the Manasoa section on the Onilahy River, south-west Madagascar. Cretaceous Research, v. 25, pp. 543-576. 
Walaszczyk, I., Wood, C.J., Lees, J.A., Peryt, D., Voigt, S., and Wiese, F., 2010, Salzgitter-Salder Quarry (Lower Saxony, Germany) and Słupia Nadbrzeżna river cliff section (central Poland): a proposed candidate composite Global Boundary Stratotype Section and Point for the Coniacian Stage (Upper Cretaceous). Acta Geologica Polonica, v. 60, pp. 445-477.

Walaszczyk, I., Lees, J.A., Peryt, D., Cobban, W.A., and Wood, C.J., 2012, Testing the congruence of the macrofossil versus microfossil record in the Turonian-Coniacian boundary succession of the Wagon MoundSpringer composite section (NE New Mexico, USA). Acta Geologica Polonica, v. 62, pp. 581-594.

Walaszczyk, I., Kopaevich, L.F., and Beniamovski, V.N., 2013, Inoceramid and foraminiferal record and biozonation of the Turonian and Coniacian (Upper Cretaceous) of the Mangyshlak Mts., western Kazakhstan. Acta Geologica Polonica, v. 63, pp. 469-487.

Walaszczyk, I., Kennedy, W.J., Dembicz, K., Gale, A.S., Praszkier, T., Rasoamiaramanana, A.H., and Randrianaly, H., 2014a, Ammonite and inoceramid biostratigraphy and biogeography of the Cenomanian through basal Middle Campanian (Upper Cretaceous) of the Morondava Basin, western Madagascar. Journal of African Earth Sciences, v. 89, pp. 79132.

Walaszczyk, I., Shank, J.A., Plint, A.G., and Cobban, W.A., 2014b, Interregional correlation of disconformities in Upper Cretaceous strata, Western Interior Seaway: Biostratigraphic and sequence-stratigraphic evidence for eustatic change. Bulletin of the Geological Society of America, v. 126, pp. 307-316.

Walaszczyk, I., Kennedy, W.J., and Paranjape, A.R., 2018, Inoceramids and associated ammonite faunas from the uppermost Turonian-lower Coniacian (Upper Cretaceous) of the Anaipadi-Saradamangalam region of the Cauvery Basin, south-east India. Acta Geologica Polonica, v. 68 , pp. 663-687.

Wellman, H.W., 1959, Divisions of the New Zealand Cretaceous. Transactions of the Royal Society of New Zealand, v. 87, pp. 99-163.

Westerman, G.E.G., 1996, Ammonoid life and habit. In: Landman, N.H., Tanabe, K. and Davis, R.A. (Eds.), Ammonoid Palaeobiology. Topics in Geobiology, v. 13, pp. 607-707.

Wiese, F., 1997, Das Turon und Unter-Coniac im Nordkantabrischen Becken (Provinz Kantabrien, Nordspanien): Faziesentwicklung, Bio-, Event- und Sequenzstratigraphie. Berliner Geowissenschaftliche Abhandlungen, v. E24, pp. 1-131.

Wiese, F., 1999, Stable isotope data $\left(\delta^{13} \mathrm{C}, \delta^{18} \mathrm{O}\right)$ from the Middle and Upper Turonian (Upper Cretaceous) of Liencres (Cantabria, northern Spain) with a comparison to northern Germany (Söhlde \& SalzgitterSalder). Newsletters on Stratigraphy, v. 37, pp. 37-62.

Wiese, F., 2000, On some Late Turonian and Early Coniacian (Upper Cretaceous) heteromorph ammonites from Germany. Acta Geologica Polonica, v. 50, pp. 407-419.

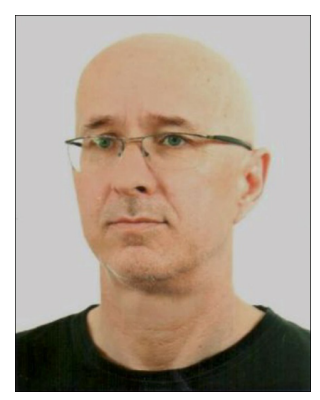

Ireneusz Walaszczyk is Professor of Earth Sciences at the University of Warsaw, where he took his PhD and habilitated in 2001. His current areas of research encompass systematics, evolution and biogeography of Late Cretaceous inoceramid bivalves from various areas of the World (Europe, Greenland, North America South Africa, Madagascar and Asia), and their stratigraphical and biogeographical potential. He teaches regional and historical geology and palaeobiogeography.
Wiese, F., 2009, The Söhlde Formation (Cenomanian, Turonian) of NW Germany: shallow marine pelagic red beds. In: Cretaceous Oceanic Red Beds: Stratigraphy, Composition, Origins, and Palaeoceanic and Palaeoclimatic Significance, SEPM Special Publication, v. 91, pp. $153-170$.

Wiese, F., and Kröger, B., 1998, Evidence for a shallowing event in the Upper Turonian (Cretaceous) Mytiloides scupini Zone of northern Germany. Acta Geologica Polonica, v. 48, pp. 265-284.

Wiese, F., Čech, S., Walaszczyk, I. and Košták, M., 2020, An upper Turonian (Upper Cretaceous) inoceramid zonation and a round-the-world trip with Mytiloides incertus (Jimbo, 1894). Zeitschrift der Deutschen Gesellschaft für Geowissenschaften - Journal of Applied and Regional Geology, v. 171, pp. 211-226.

Wignall, P.B., and Myers, K.J., 1988, Interpreting the benthic oxygen levels in mudrocks: a new approach. Geology, v. 16, pp. 452-455.

Williams, G.L., Brinkhuis, H., Pearce, M.A., Fensome, R.A., and Weegink, J.W., 2004, Southern Ocean and global dinoflagellate cyst events compared: index events for the Late Cretaceous-Neogene. In: Exon, N.F., Kennett, J.P., Malone, M.J., (Eds.), Proceedings of the Ocean Drilling Program, Scientific Results, v. 189, pp. 1-98.

Wilson, G.J., 1984, New Zealand Late Jurassic to Eocene dinoflagellate stratigraphy—a summary. Newsletters on Stratigraphy, v. 13, pp. 104117.

Wood, C.J., and Ernst, G., 1998, Turonian-Coniacian of Salzgitter-Salder. In: Mutterlose, J., Bornemann, A., Rauer, S., Spaeth, C., and Wood, C.J., (Eds), Key localities of the northwest European Cretaceous. Bochumer Geologische und Geotechnische Arbeiten, v. 48, pp. 94 102.

Wood, C.J., Ernst, G., and Rasemann, G., 1984, The Turonian-Coniacian stage boundary in Lower Saxony (Germany) and adjacent areas: the Saltzgitter-Salder Quarry as a proposed international standard section. Bulletin of the Geological Society of Denmark, v. 33, pp. 225-238.

Wood, C.J., Walaszczyk, I., Mortimore, R.N., and Woods, M.A., 2004, New observations on the inoceramid biostratigraphy of the higher part of the Upper Turonian and the Turonian - Coniacian boundary transition in Poland, Germany and the UK. Acta Geologica Polonica, v. 54, pp. 541-549.

Wright, C.W., 1979, The ammonites of the English Chalk Rock (Upper Turonian). Bulletin of the British Museum (Natural History) (Geology series), v. 31, pp. 281-332.

Young, J.R., Wade, B.S., Huber, B.T.,and editors, 2005-2015, pforams @ mikrotax website. http://www.mikrotax.org/pforams.

Zonova, T.S., and Jagt-Yazykova, E.A., 2008, The scheme of biostratigraphic subdivision of the Coniacian Stage (Upper Cretaceous) of the northern Pacific palaeobiogeographic region. Neftegazovaya Geologia. Teoria i Praktika, v. 3, pp. 1-19.

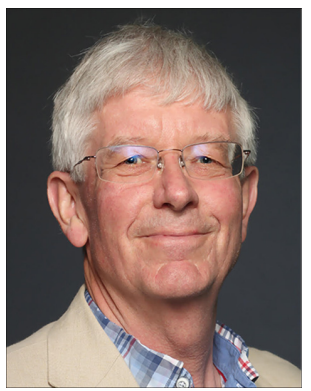

Ian Jarvis is Emeritus Professor at Kingston University London. His research focuses on sedimentary processes in epicontinental seas and the deep ocean, and the development of novel analytical techniques. Topics include the use of Cretaceous pelagic carbonates as palaeoenvironmental archives, the utility of dinoflagellate cysts as stratigraphic and palaeoenvironmental tools, the origin of phosphorites and other marine authigenic minerals, and the mechanisms and history of turbidite deposition in the Atlantic Ocean. A particular interest is the application of carbon isotope chemostratigraphy to refine the geological timescale and to improve understanding of interactions between biogeochemical cycles, climate and palaeoenvironmental change. 


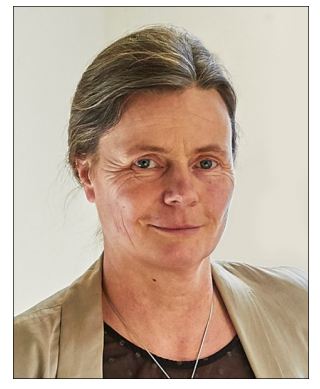

Silke Voigt is Professor of Sedimentology at Goethe University Frankfurt. Her research centres on the response of marine and terrestrial sedimentary systems to Mesozoic and Cenozoic greenhouse climate change. Her expertise broadly combines the fields of stratigraphy, sedimentology, geochemistry and palaeoclimatology. Specific topics comprise the orbital forcing of sedimentary processes on marine shelves and in continental basins, the development of Late Cretaceous carbon isotope stratigraphy on orbital timescales as a stratigraphic tool, and the history of chemical weathering, carbon cycling, and ocean circulation, chemistry and temperature on a multi-million-year time scale. 